\title{
CARBONATE DEPOSITION IN RESTRICTED BASINS: A PLIOCENE CASE STUDY FROM THE CENTRAL MEDITERRANEAN (NORTHWESTERN APENNINES), ITALY
}

\author{
RONALD NALIN, ${ }^{1}$ MASSIMILIANO GHINASSI, ${ }^{2}$ LUCA M. FORESI, ${ }^{3,4}$ AND EDOARDO DALLANAVE ${ }^{5}$ \\ ${ }^{1}$ Geoscience Research Institute, 11060 Campus Street, Loma Linda 92350 California, U.S.A. \\ ${ }^{2}$ Università degli Studi di Padova, Dipartimento di Geoscienze, Via Giovanni Gradenigo 6, 35131 Padova, Italy \\ ${ }^{3}$ Università di Siena, Dipartimento di Scienze Fisiche, della Terra e dell'Ambiente, Strada Laterina 8, 53100 Siena, Italy \\ ${ }^{4}$ Institute of Geosciences and Earth Resources, CNR Pisa Research Area, Via G. Moruzzi 1, 56124 Pisa, Italy \\ ${ }^{5}$ Department of Earth and Environmental Science, Ludwig-Maximilians University, Theresienstrasse 41, Munich D-80333, Germany \\ email:Rnalin@llu.edu
}

\begin{abstract}
Carbonate depositional models are often informed by the study of platforms of good lateral continuity and sizable thickness, because of their significance in petroleum geology. However, spatially restricted and more ephemeral carbonate accumulations can be an important but frequently overlooked component of otherwise siliciclastic-dominated or mixed carbonate-siliciclastic systems. Pliocene successions of Tuscany and the Tyrrhenian shelf (Northern Apennines, Italy) record a regional pulse of nontropical carbonate deposition across several restricted basins that has not yet been precisely constrained in its genesis and correlation. This study investigates the stratigraphic expression of these carbonates to extract general aspects applicable to carbonate sedimentation across tectonically structured and physiographically complex shelves. Analyses of the extension, composition, facies, and sequence stratigraphic architecture of the studied Piacenzian carbonate units are complemented by new biostratigraphic and magnetostratigraphic data, which document the slightly diachronous development of the carbonates within Mediterranean planktonic foraminifera Subzones MPL4b and MPL5a and magnetic polarity Chron C2An. The carbonate units are part of a regionally defined, tectonically controlled sequence, and represent the first transgressive unit overlying the basal sequence boundary, but are also found in the regressive portion of the sequence. Collectively, the units document the establishment of a shallow-marine carbonate factory, dominated by calcareous red algae, the larger benthic foraminifer Amphistegina, and heterozoan skeletal components, along the margins of a complex, archipelago-like coastal domain. A review of the studied successions and other examples from the literature indicates that carbonate accumulations in settings with varied coastal physiography and active partitioning of depocenters are generally characterized by: a) spatial discontinuity; b) an overall skeletal association consistent across separate basins, but with local variability in dominant skeletal components; c) preferential accumulation along basin margins or over isolated structural highs not in direct proximity to a hinterland with major drainage systems; d) predominance of low- to moderate-energy facies; e) preferential onset of deposition during transgression, with possible development of mixed carbonate-siliciclastic facies; and f) differing internal stratigraphic architecture tied to the specific subsidence and uplift history of coeval individual basins. These observations built upon the study of mid-Piacenzian carbonate units from the central Mediterranean contribute to the refinement of carbonate facies models and their application in the fields of sequence stratigraphy and basin analysis.
\end{abstract}

\section{INTRODUCTION}

Biogenic carbonates are sedimentary products that record not only the influence of physical processes but also the signature of ecological conditions at the time of deposition (Schlager 1991; Pomar and Kendall 2008). As such, establishment of a carbonate-producing system can reflect general climate-oceanographic changes and, if synchronous in nature, even acquire chronostratigraphic value when documented in rock successions (Brett et al. 2012). Notwithstanding the importance of environmental factors in influencing the onset, style, and demise of carbonate factories (Pomar 2001; Schlager 2003; Westphal et al. 2010), shallow marine carbonate deposits form at a wide range of latitudes and under a broad spectrum of environmental conditions (James 1997; Lukasik and Simo
2008). Therefore, development of shallow-water carbonate platforms is controlled at the most fundamental level by the availability and permanence of a depositional area within the photic zone, and is ultimately a function of eustasy, tectonics, and accumulation rates (Lukasik and Simo 2008). This understanding has firmly placed the study of carbonate platforms within the framework of sequence stratigraphy and basin analysis, resulting in genetic classifications based on tectonic settings (Bosence 2005) and raising interest in investigating causes of preferential partitioning of carbonates in distinct portions of stratigraphic sequences (Holland 1993; Brachert et al. 2003; Massari and D'Alessandro 2012; Zeller et al. 2015). Whereas such a stratigraphic approach has been widely applied to the study of carbonate platforms of sizable lateral extent and 
thickness, less emphasis has been placed on developing models for spatially restricted and more ephemeral shallow marine carbonate deposits preserved in mixed carbonate-siliciclastic systems of complex structured coastal domains. This paper addresses the subject of the stratigraphic expression of carbonate deposition in restricted basins presenting a Pliocene case study from the central Mediterranean in the Tuscany region of Italy, where shallow-marine carbonate bodies occurring within otherwise siliciclastic-dominated successions record a regionally widespread onset of nontropical carbonate sedimentation.

In the Mediterranean region, stratal architecture and composition of numerous Neogene to Quaternary carbonate units have been analyzed as stratigraphic and paleoecological archives at the regional and local scale (e.g., Brachert et al. 1996; Esteban 1996; Braga and Aguirre 2001; Pomar et al. 2004; Braga et al. 2006; Reuter et al. 2006; Massari and D'Alessandro 2012). However, carbonate deposits from the NeogeneQuaternary basins of the inner Northern Apennines (Tuscany, Italy) have, to date, received comparatively little attention. The aims of this study are: 1) to present the first unified analysis and review of the Pliocene Tuscan carbonate units, with description of their skeletal association, facies, and stratigraphic architecture; 2) to establish a chronostratigraphic framework for the carbonate units, through magnetostratigraphy and calcareousplankton biostratigraphy; 3) to illustrate the effect of differential subsidence and uplift on the stratigraphic expression of an interval of carbonate deposition unfolding over a tectonically structured shelf; and 4) to extract from the studied units and a review of the literature some general patterns governing shallow-marine carbonate deposition in restricted basins.

\section{GEOLOGICAL SETTING}

The Northern Apennines consist of a NW-SE-oriented thrust-and-fold belt (Fig. 1), the evolution of which was related to the closure of an oceanic segment interposed between European and African crustal blocks (Boccaletti et al. 1971; Kligfield 1979). From Oligocene to early Miocene, collision along this convergent margin led to the emplacement and deformation of tectonic nappes pertaining to the former oceanic domain and to the eastern continental margin of Adria, a microplate of the African domain (Carmignani et al. 2001). From early to late Miocene, a series of basins resting on the thrust-and-fold belt begun to develop on the Tyrrhenian margin of the Apennines (Bossio et al. 1993; Martini and Sagri 1993; Cornamusini et al. 2014) (Fig. 1). The basins are bounded by roughly NNW-SSE-oriented structural highs and segmented by NE-SWoriented transverse morphotectonic alignments (Bartole 1995; Pascucci et al. 2007), and are preserved partly onshore in Tuscany and partly offshore on the North Tyrrhenian Sea (Bartole 1995; Pascucci et al. 1999) (Fig. 1). The tectonic regime controlling genesis and evolution of the basins is still a subject of debate, with some studies favoring dominantly extensional mechanisms (Martini and Sagri 1993; Pascucci et al. 1999; Carmignani et al. 2001; Martini et al. 2001; Pascucci et al. 2006; Pauselli et al. 2006; Brogi and Liotta 2008; Brogi 2011) and others stressing the role of compressional tectonics (Bernini et al. 1990; Boccaletti and Sani 1998; Bonini and Sani 2002; Finetti 2006; Benvenuti et al. 2014).

Based on the stratigraphic analysis of the infill of the basins, Martini and Sagri (1993) proposed a subdivision between so-called "peripheral" and "central" basins. Central basins preserve Miocene deposits and were affected by several episodes of marine sedimentation. Peripheral basins, on the other hand, were activated during the Pliocene and their infill consists exclusively of continental deposits. This study concentrates on the central basins, which are geographically located west of the Cetona-Chianti ridge (Fig. 1).

The infill of the central basins has been subdivided in several unconformity-bounded sequences, most of which can be confidently correlated across the basins (Boccaletti and Sani 1998; Pascucci et al.
1999; Martini et al. 2001). These sequences preserve evidence of multiple episodes of shallow marine deposition during transgression, namely in the late Serravallian-early Tortonian, early Messinian, Zanclean, Piacenzian, and Pleistocene (Bossio et al. 1998; Pascucci et al. 1999; Pascucci et al. 2007).

Notwithstanding the repeated establishment of marine conditions, carbonate units are rare in the basins. In fact, the only volumetrically significant phase of carbonate sedimentation is recorded in Pliocene deposits, with more restricted and isolated occurrences in the lower Messinian (the coral-bearing Rosignano Limestone (Bossio et al. 1993)) and Pleistocene. The Pliocene carbonates are historically known in the regional literature with the informal name of Amphistegina Limestone and have been mapped with different local lithostratigraphic names (e.g., Costantini et al. 2002; Lazzarotto et al. 2002). Prior to the present work, very few studies focusing on stratigraphy and sedimentology of the carbonate units had been conducted (Bossio et al. 1981; Conti et al. 1983; Capezzuoli et al. 2006; Checconi et al. 2007; Nalin et al. 2010). These studies also lacked a comprehensive discussion of the overall stratigraphic and paleoecologic significance of the carbonates.

\section{METHODS}

Localities where Pliocene carbonates had been mentioned in the literature were surveyed and mapped at the scale of 1:10,000. Data were collected from 14 localities situated in the Volterra, RadicondoliChiusdino, Albegna, Valdelsa, Val d'Orcia, and Siena-Radicofani basins and in the island of Pianosa (Fig. 1). Fieldwork was complemented by collection of 157 samples for petrographic analysis of thin sections, 148 samples for magnetostratigraphic analysis, and 25 samples for calcareous plankton biostratigraphic analysis to integrate already published biostratigraphic data (e.g., Bossio et al. 1991b; Bossio et al. 1991c; Costantini et al. 2002; Lazzarotto et al. 2002; Bossio et al. 2003-2004; Capezzuoli et al. 2005; Riforgiato et al. 2005).

Facies analysis was based on composition, sedimentary structures, texture, and constituent skeletal components, as observed in the field and in thin sections. The term "hybrid" was used for facies where the siliciclastic fraction was between $20 \%$ and $50 \%$, as estimated in thinsection analysis through visual-comparison charts. In this paper, the Argille Azzurre Fm., a term traditionally applied indistinctly to all Pliocene offshore clays in the Tuscan basins, was informally divided into lower and upper Argille Azzurre Fm. (Fig. 2). The distinction was necessary to avoid confusion, because these clays belong to two separate, unconformable stratigraphic sequences, Zanclean and Piacenzian respectively, and can be found above or below the studied carbonate units.

Paleomagnetic samples were drilled at all sites (except for Pianosa) with a gasoline-powered drill and oriented with a magnetic compass. From each core a standard $\sim 11 \mathrm{~cm}^{3}$ oriented specimen was obtained for paleomagnetic analysis. At Pianosa a total of 10 oriented hand samples were collected and successively sliced in the laboratory in multiple $8 \mathrm{~cm}^{3}$ cubes. All the oriented specimens were stepwise thermally demagnetized up to a temperature of $575{ }^{\circ} \mathrm{C}$, and the natural remanent magnetization (NRM) of the specimens was measured after each demagnetization step. A set of representative specimens from the rock-cutting residuals was used to investigate the magnetic properties of the sediments by means of thermomagnetic curves analyses. The details about paleo- and rockmagnetic methods and analyses are described in the file SM1 (see Supplemental Material).

Samples for biostratigraphic analysis were prepared with standard techniques, by washing and sieving $\sim 200 \mathrm{~g}$ of sample for study of the foraminiferal content $(>64 \mu \mathrm{m})$ and through preparation of smear slides for study of the calcareous nannofossils. The biozonation schemes adopted in this study are those of Rio et al. (1990) for calcareous nannofossils and Cita (1975) emended by Sprovieri (1992) for planktonic foraminifera. Age 
of biohorizons, magnetic polarity reversals, and chronostratigraphic boundaries follows Lourens et al. (2004) and Cohen et al. (2013).

\section{RESULTS}

This section presents the results of the sedimentologic and chronostratigraphic analysis of the carbonate units for each basin. The general attributes of the discussed localities are summarized in Table 1, description of the identified facies is provided in Table 2 (with representative field and thin-section illustrations in the supplementary material, SM2), and a synthetic panel of the chronostratigraphic results is presented in Table 3 and Figure 2. Of the 148 samples collected for magnetostratigraphic analysis, 97 gave reliable linear characteristic remanent magnetization (ChRM) component directions. Of the 25 samples collected for biostratigraphic analysis, 18 yielded non-reworked associations with significant planktonic foraminifera and nannoplankton markers for biozonation. A compilation of symbols used in the measured stratigraphic logs is shown in Figure 3.

\section{Volterra Basin}

Pliocene carbonates are known from the Casciana Terme area (Fig. 1), in the northwestern sector of the Volterra basin (Bossio et al. 1981) and were investigated at the Parlascio site, where a composite section (log 1: $\mathrm{N}^{\circ} 3^{\circ}$ $31.442^{\prime} \mathrm{E} 10^{\circ} 36.268^{\prime} ; \log 2: \mathrm{N}^{\circ} 3^{\circ} 31.399^{\prime} \mathrm{E} 10^{\circ} 36.211^{\prime}$ ), about $30 \mathrm{~m}$ thick, was measured (Fig. 4A, B).

Casciana Terme Unit: Description.-The section starts with a basal unconformity where the Zanclean lower Argille Azzure Fm. is overlain by about $3 \mathrm{~m}$ of hybrid sandy and gravelly deposits (facies $\mathrm{Cg} 1, \mathrm{Ha} 1$ ) (Fig. 4). This basal interval fines upward into a 1.5 -m-thick, intensely bioturbated packstone (facies Fg1), sharply overlain by the bottomsets of an Amphistegina-rich clinostratified body, about $6.5 \mathrm{~m}$ thick (Fig. 4C). Foresets of the clinostratified body show a general upward increase in inclination (up to $15^{\circ}$ ) and consist of plane-parallel-stratified to massive beds containing some planar cross-stratified sets, alternated with highly bioturbated beds (facies Amph1), generally dipping toward the north. A slightly irregular erosional surface separates the foreset strata from the overlying horizontally bedded, 5-m-thick package (Fig. 4D). The basal 30 $\mathrm{cm}$ of the horizontally bedded package are rich in large disarticulated ostreid and pectinid shells (up to $10 \mathrm{~cm}$ in size), rhodoliths, and lithic pebbles often bored and encrusted by a thin coating of red algae. The rest of the package consists of crudely bedded Amphistegina calcarenite, with local preservation of plane-parallel stratification and hummocky crossstratification (facies Cal1, Amph2). A fining-upward trend can be distinguished from the upper two meters of the Amphistegina-rich calcarenite into an overlying 80 -cm-thick, fine-grained packstone (facies Fg1). The packstone coarsens upward into the bottomsets of a second clinostratified body, about $8 \mathrm{~m}$ thick, consisting of bioturbated, massive, or plane-parallel-stratified, 2-10-cm-thick beds of Amphistegina grainstone (facies Amph1). The clinoform has a composite architecture, with at least three stacked sets of foreset beds separated by internal downlapping surfaces (Fig. 4E). The top of the clinostratified body is erosionally truncated and overlain by a 2 -m-thick package of red algae floatstone to rudstone (facies Alg1) with crude horizontal stratification. An increase in terrigenous content in this uppermost package marks the gradational upward transition to a nearshore siliciclastic sand unit, not logged in the measured section (Villamagna Formation of Costantini et al., 2002). The results of magnetobiostratigraphic analyses (Table 3) allow constraint of the Casciana Terme succession between the Globorotalia bononiensis LO (lowest occurrence) and the top of Subchron C2An.2n (Fig. 2).

Casciana Terme Unit: Stratigraphic Interpretation.-The succession preserved at the Parlascio site is interpreted as recording at least two transgressive-regressive pulses within fully subtidal deposits of an unconformably based sequence. The sand and gravel beds above the basal unconformity and the overlying fine-grained packstone are thought to document an initial transgressive trend reflected by a concurrent decrease in siliciclastic content, grain size, and abundance of physical structures. The lower Amphistegina-dominated clinostratified body records basinward progradation during the regressive phase of the first cycle. Clinoforms are a common feature of many types of carbonate platforms (Quiquerez and Dromart 2006). They differ from simple cross-stratification for the larger scale and a genesis reflecting deposition over an inclined profile rather than lateral migration of a bedform. Modern and paleoecological studies of Mediterranean Amphistegina indicate predominant production in shallow, inner-ramp environments (Hyams et al. 2002; Guillem et al. 2008; Koukousioura et al. 2010). Accumulation of Amphistegina tests to form a clinostratified body could be attributed either to redistribution below storm-wave base by offshore-directed flows during storm events (Pomar and Tropeano 2001; Massari and Chiocci 2006) or to prevalently in situ deposition on the inclined segment of a distally steepened ramp (Pomar 2001). However, the alternation of planar-stratified and bioturbated beds favors the model of intermittent offshore transport with subordinate parautochothonous accumulation. The erosional surface truncating the lower clinoform unit is interpreted as formed subaqueously by wave action in response to base-level drop, and the overlying 30-cm-thick coarsegrained interval as a relatively condensed lag. A second transgressive pulse is thought to be reflected by the overlying fining-upward package, with the ensuing regressive phase documented by the upper Amphisteginadominated clinostratified body. The occurrence of sets with different dip directions within the clinostratified body could be the result of backset stratification or lateral onlap of adjacent lobes on the face of the clinoform front. Deposits rich in red algae capping the succession represent an example of maërl, a facies consisting of unattached, often interlocked, red algae branches and rhodoliths, which in the modern Mediterranean reaches optimum development in mid-ramp, relatively deep (between 30 and $80 \mathrm{~m}$ ) settings (Canals and Ballesteros 1997; Brandano and Civitelli 2007; Sciberras et al. 2009). Considering the erosional base of this unit and its transition to nearshore, siliciclastic-dominated deposits (Villamagna Fm.), the maërl unit could encompass a third separate transgressive-regressive fluctuation.

\section{Radicondoli-Chiusdino Basin}

Pliocene carbonates in the Radicondoli-Chiusdino basin are known from its northeastern margin (Pomarance area) and the southernmost termination of the basin (Roccastrada area) (Fig. 1) (Bossio et al. 1991a; Bossio et al. 1991b; Bossio et al. 1991c; Bossio et al. 1993). The carbonates of the Pomarance area are known as the San Dalmazio Fm. (Lazzarotto et al. 2002) and were investigated at two separate sites (Pavone Creek and Bulera sections) which are $\sim 3 \mathrm{~km}$ apart (Fig. 5A).

FIG. 1.-Simplified tectonic and geologic maps of the study area. A) Tectonic map of the Northern Apennines, with indication of the main Neogene-Quaternary Tuscan basins and localities discussed in this study. Modified after Pascucci et al. (2007). AL, Albegna basin; BC, Baccinello-Cinigiano basin; CH, Val di Chiana basin; CTC, Cetona-Chianti Ridge; EL, Valdelsa basin; RA, Siena-Radicofani basin; RD, Radicondoli-Chiusdino basin; VO, Volterra basin. B) Simplified geologic map of the central Tuscan basins (modified after Bossio et al. 1993), with location of areas mapped and illustrated in following figures. 

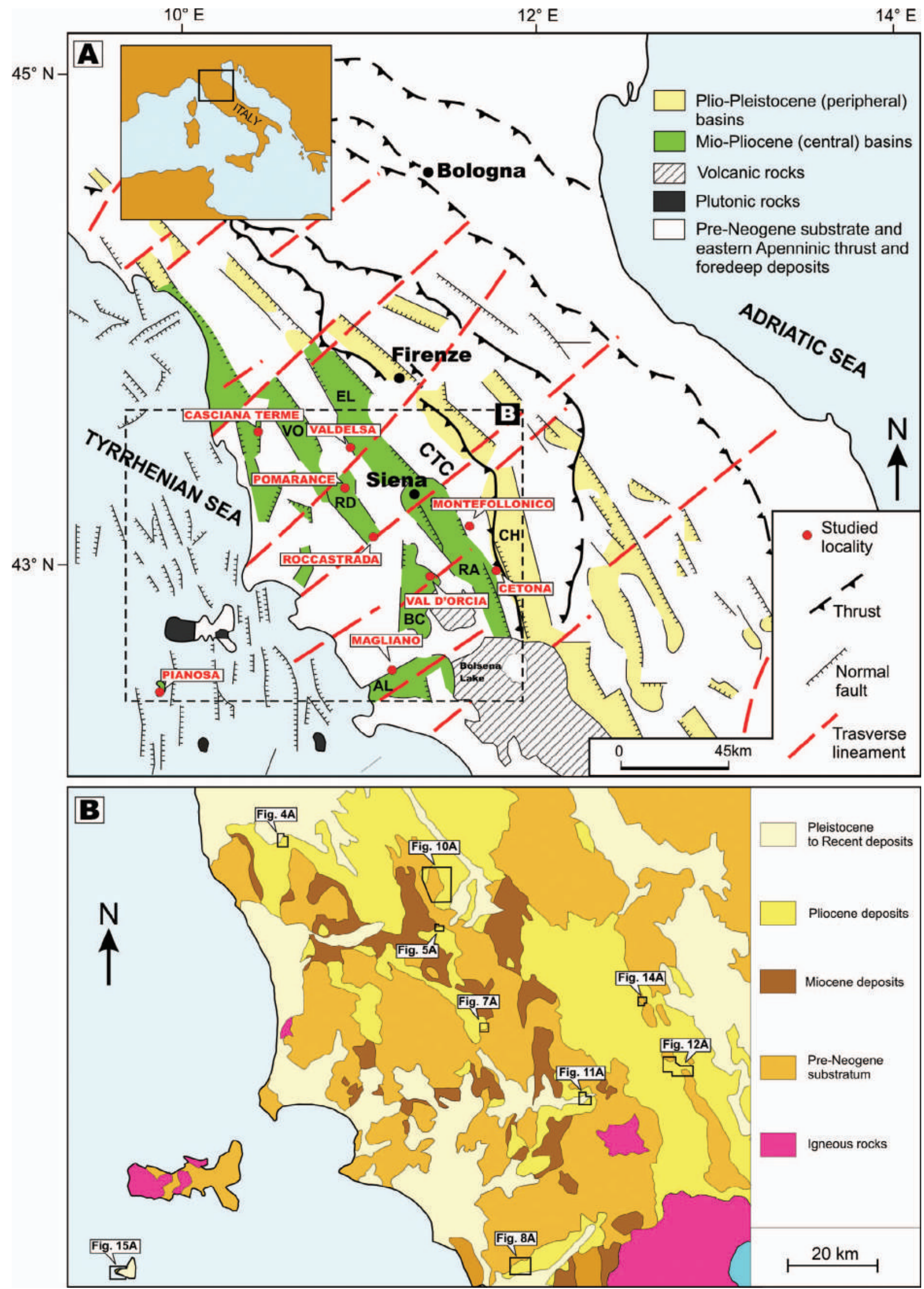


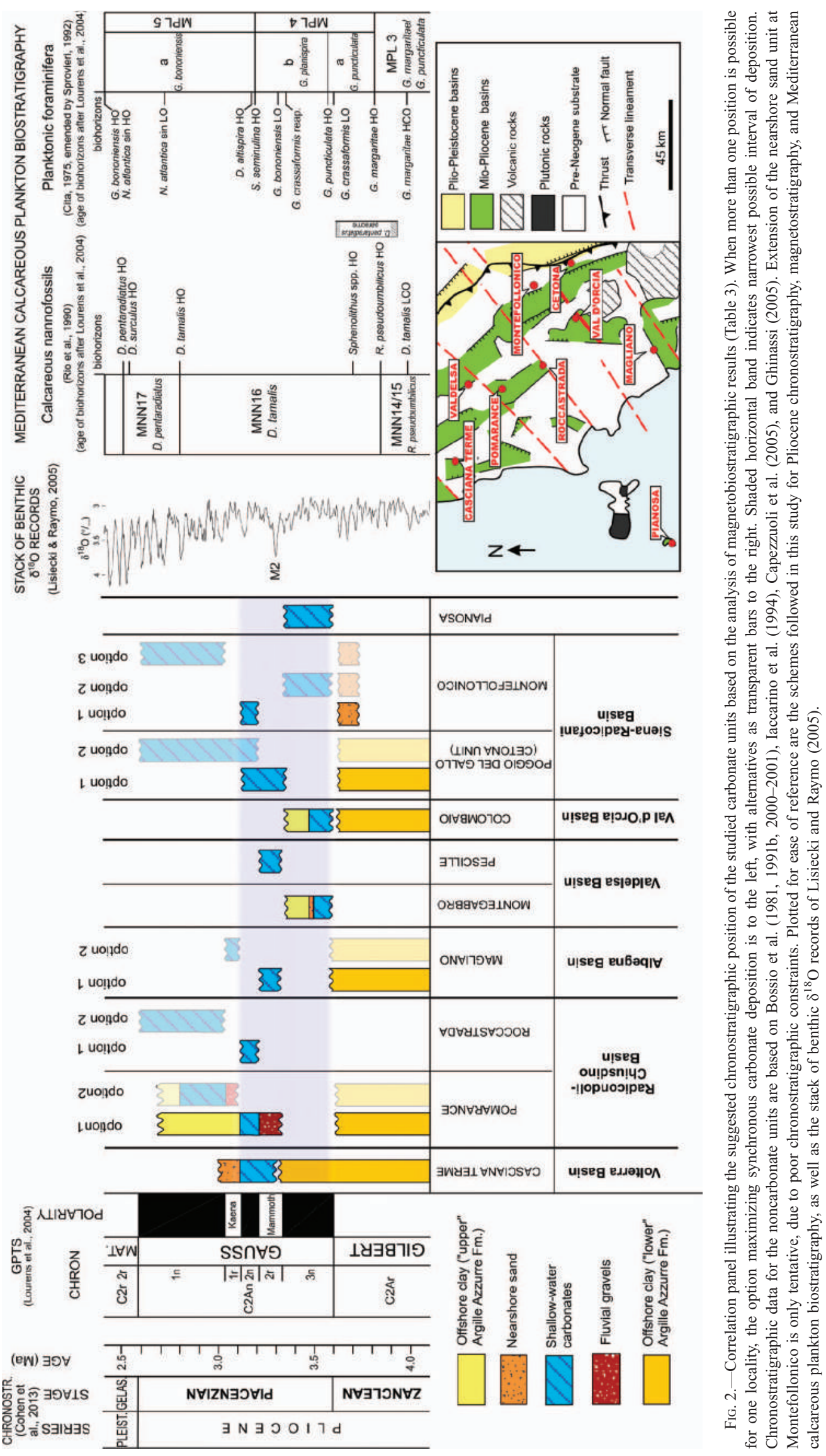




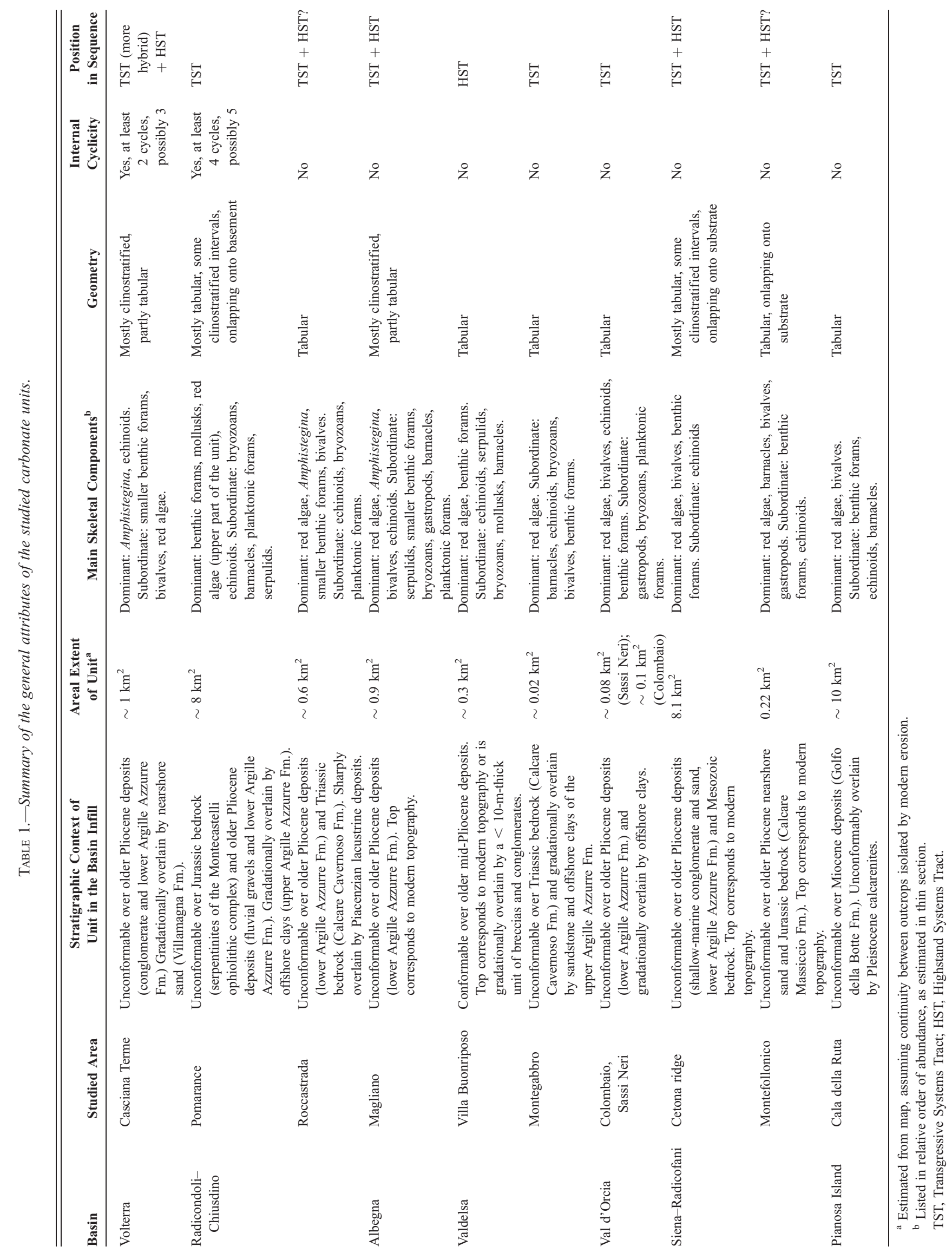


TABLE 2.-List of the identified facies.

\begin{tabular}{lcl}
\hline \hline Category & Facies (with Code) & \multicolumn{1}{c}{$\begin{array}{c}\text { Sections where } \\
\text { Facies Occurs }\end{array}$} \\
\hline $\begin{array}{l}\text { Coarse-grained } \\
\text { facies }\end{array}$ & $\begin{array}{c}\text { Polymictic } \\
\text { conglomerate }(\mathrm{Cg} 1)\end{array}$ & $\begin{array}{l}\text { Casciana Terme, } \\
\text { Roccastrada, } \\
\end{array}$ \\
& $\begin{array}{l}\text { Montegabbro, Cava } \\
\text { Gosti, Montefollonico, } \\
\end{array}$ & Pianosa
\end{tabular}

Basal breccia $(\mathrm{Cg} 2)$

Pavone Creek, Cava Gosti

Fine-grained facies

$\begin{array}{cc}\text { Amphistegina- } & \text { Amphistegina } \\ \text { dominated } & \text { packstone to } \\ \text { facies } & \text { grainstone in foreset } \\ & \text { beds (Amph1) }\end{array}$

\begin{abstract}
Amphistegina grainstone (Amph2)
\end{abstract}

keletal packstone beds (Fg1) Casciana Terme, Pavone
Creek, Bulera
Casciana Terme, Patrignone Creek beds (Amph1)

Shellbeds

Ostreid shellbed with terrigenous matrix (Sh1)

$\begin{array}{ll}\begin{array}{c}\text { Neopycnodonta } \\ \text { shellbed (Sh2) }\end{array} & \text { Pavone Creek } \\ & \\ \begin{array}{c}\text { Pectinid and ostreid } \\ \text { shellbed (Sh3) }\end{array} & \begin{array}{c}\text { Colombaio, Poggo del } \\ \text { Gallo }\end{array}\end{array}$

Isognomon shellbed (Sh4)
Pavone Creek Gallo

Pianosa

\section{Description}

Clast-supported, granule to cobble conglomerate, with crude planar stratification, locally normally graded. Occurs above basal unconformity or in beds and lenses up to $15 \mathrm{~cm}$ thick with erosional base. Clasts are subangular to rounded, frequently bored. Lithic clasts dominate, but disarticulated ostreid and pectinid shells and rhodoliths are also common. Matrix consists of facies Fg1 or facies Ha2.

Chaotic breccia, clast- or matrix-supported, with angular lithic clasts up to $1 \mathrm{~m}$ in size. Found in lenses or beds above basal unconformity.

Well sorted (with local bimodal sorting), fine-grained skeletal packstone. Forms massive recessive layers, up to $2 \mathrm{~m}$ thick, with rare traces of planar lamination and common bioturbation. Skeletal components are smaller benthic and planktonic forams, Amphistegina, echinoid, mollusk, bryozoan, and red algae fragments, with a subordinate siliciclastic component of fine- to mediumsand-sized quartz.

Moderately to poorly sorted packstone to grainstone (locally rudstone) in parallel-stratified to massive foreset beds $\left(1-10 \mathrm{~cm}\right.$ thick, average inclination $10-15^{\circ}$ ), locally amalgamated by intense bioturbation. Planar cross-stratified sets (up to $50 \mathrm{~cm}$ thick) are locally observed in the foresets. Beside Amphistegina, skeletal components include echinoid, bivalve, red algae, and serpulid fragments, and smaller benthic and planktonic forams. A subordinate component of medium- to coarse-sand-sized, angular quartz can be locally present. Preferential plane-parallel orientation of elongated particles is common.

Moderately to well sorted skeletal grainstone, mostly massive, with traces of horizontal stratification and lowangle cross-stratification. Skeletal components include Amphistegina, red algae, smaller benthic forams, echinoid, bivalve, and brachiopod fragments.

Densely to loosely packed concentration of ostreid shells, up to $20 \mathrm{~cm}$ in size, moderately to well sorted. Shells are mostly disarticulated and flat-lying. Matrix is rich in coarse lithic clasts (facies $\mathrm{Cg} 1$ and $\mathrm{Ha} 2$ ). Limited lateral continuity. Found above basal unconformity on hard substrate.

Densely packed concentration of Neopycnodonta shells (up to $8 \mathrm{~cm}$ in size) moderately sorted and locally cemented to each other. Matrix consists of skeletal wackestone to packstone. Forms bed laterally continuous for tens of meters, with crude horizontal stratification.

Densely to moderately packed concentration of pectinid (mostly Flabellipecten and Chlamys) and/or ostreid shells. Valves are disarticulated, subhorizontal, in beds 5$20 \mathrm{~cm}$ thick, locally with erosionally scoured base and normal grading. Commonly associated with rhodoliths, red algal branches, and fragments of Ditrupa.

Densely packed concentration of Isognomon maxillatus (Lamarck, 1801) shells, up to $25 \mathrm{~cm}$ in size, moderately to well sorted. Articulated shells are dominant. Most specimens preserved as molds. Individual beds are up to $70 \mathrm{~cm}$ thick and can form banks up to $1.7 \mathrm{~m}$ thick, internally partitioned by discontinuous lenses and beds of skeletal packstone to rudstone rich in smaller fragments of Isognomon shells.
Interpretation

Basal transgressive lag developed in a nearshore setting, in proximity of coastal exposures of substrate; localized storm lag deposit, filling base of erosional scours.

Colluvium or rocky cliff deposits reworked during marine transgression over bedrock.

Settling of fine-grained suspended load in low-energy environment (sheltered coastal embayment or shelf mostly below storm-wave base), admixed with parautochthonous skeletal particles and terrigenous granules transported during infrequent high-energy events.

Parautochthonous to transported accumulation of skeletal particles on sloping depositional face of clinostratified body. Developed mostly below stormwave base by periodic downwelling flows and settling of fine sediment from suspension. Cross-sets generated by infill of collapse scours or erosional troughs in the foreset face.

Partially winnowed parautochthonous accumulation of skeletal particles in moderateenergy shallow bottoms, in proximal coastal setting.

Parautochthonous accumulation of oyster shells, with localized reworking of assemblage growing on coarse substrate, in shallow relatively turbid waters.

Parautochthonous to in situ accumulation of Neopycnodonta shells due to ecological aggregation on soft substrate.

Allochthonous to parauthochthonous assemblage of pectinid shells hydraulically sorted and deposited during episodic storm events. Some disturbance by bioturbation.

Parautochthonous to in situ assemblage of Isognomon maxillatus shells, colonizing a shallow-water, moderately agitated substrate, episodically disturbed by higher-energy events. 
TABLE 2.-Continued.

\begin{tabular}{|c|c|c|c|c|}
\hline Category & Facies (with Code) & $\begin{array}{l}\text { Sections where } \\
\text { Facies Occurs }\end{array}$ & Description & Interpretation \\
\hline \multirow[t]{3}{*}{$\begin{array}{l}\text { Red algae- } \\
\text { dominated } \\
\text { facies }\end{array}$} & Maërl (Alg1) & $\begin{array}{l}\text { Casciana Terme, } \\
\text { Roccastrada, Magliano, } \\
\text { Montegabbro, } \\
\text { Colombaio, Poggio del } \\
\text { Gallo, Montefollonico, } \\
\text { Pianosa }\end{array}$ & $\begin{array}{l}\text { Red algal floatstone to rudstone, in massive beds, } \\
\text { consisting of }>50 \% \text { unattached, fruticose branches of } \\
\text { non-geniculate coralline algae, up to } 3 \mathrm{~cm} \text { long. } \\
\text { Subordinate components include Amphistegina, bivalve, } \\
\text { echinoid, bryozoan, and barnacle fragments. Matrix } \\
\text { consists of poorly sorted skeletal packstone to } \\
\text { wackestone, locally with very fine to medium angular } \\
\text { siliciclastic sand. May include lumpy to fruticose } \\
\text { rhodoliths up to } 5 \mathrm{~cm} \text { in size, and scattered bivalve } \\
\text { shells. Can occur in foreset beds of clinoformed unit. }\end{array}$ & $\begin{array}{l}\text { Parautochthonous accumulation of } \\
\text { algal thalli growing in a low- } \\
\text { energy setting, episodically } \\
\text { affected by higher-energy } \\
\text { events. }\end{array}$ \\
\hline & $\begin{array}{l}\text { Red algae grainstone } \\
\text { (Alg2) }\end{array}$ & Poggio del Gallo & $\begin{array}{l}\text { Skeletal grainstone forming massive beds } 20-40 \mathrm{~cm} \text { thick, } \\
\text { consisting of }>50 \% \text { fragments of red algae and sparse } \\
\text { unattached red algal branches (up to } 3 \mathrm{~cm} \text { in size). } \\
\text { Subordinate components include smaller benthic } \\
\text { forams, bivalve and echinoid fragments. Intergranular } \\
\text { porosity is filled with microsparitic cement. } \\
\text { Bioturbation is common. }\end{array}$ & $\begin{array}{l}\text { Allochthonous accumulation of } \\
\text { fragmented algal thalli and other } \\
\text { bioclastic material, deposited } \\
\text { above storm-wave base and } \\
\text { periodically winnowed. }\end{array}$ \\
\hline & $\begin{array}{l}\text { Red algae grainstone to } \\
\text { rudstone in foreset } \\
\text { beds }(\mathrm{Alg} 3)\end{array}$ & Magliano & $\begin{array}{l}\text { Skeletal grainstone to rudstone, moderately to poorly } \\
\text { sorted in massive to plane-parallel stratified foreset beds } \\
\text { ( } 5-15 \mathrm{~cm} \text { thick), with characteristic alternation of } \\
\text { rudstone and grainstone layers. Rudstone layers have } \\
\text { sharp base and can show normal grading. Branches and } \\
\text { abraded fragments of red algae are the dominant } \\
\text { skeletal component, followed by Amphistegina, bivalve, } \\
\text { echinoid, smaller benthic forams, barnacle, serpulid, } \\
\text { bryozoan, and gastropod fragments. A medium- to } \\
\text { coarse-sand-sized siliciclastic component is also locally } \\
\text { present. Intergranular spaces are partially void } \\
\text { (openwork texture). }\end{array}$ & $\begin{array}{l}\text { Transported skeletal particles } \\
\text { deposited by downwelling flows } \\
\text { on face of clinoformed unit. } \\
\text { Normal grading indicates } \\
\text { deposition during waning stage } \\
\text { of flows. Openwork texture and } \\
\text { lack of fines indicate either } \\
\text { well-winnowed source of } \\
\text { sediment or bypass and } \\
\text { deposition of fines farther } \\
\text { offshore. }\end{array}$ \\
\hline
\end{tabular}

$\begin{array}{ccc}\begin{array}{c}\text { Hybrid } \\ \text { arenite }\end{array} & \text { Well to moderately } & \text { Casciana Terme, } \\ \text { facies } & \text { (Ha1) hybrid arenite } & \text { Patrignone Creek, } \\ & \text { Montegabbro }\end{array}$

Poorly to moderately sorted hybrid arenite (Ha2)

Hybrid arenite in foreset beds (Ha3)

Patrignone Creek,
Magliano, Bulera

Calcarenite Skeletal packstone facies
Pavone Creek, Bulera, Montefollonico, Pianosa
Casciana Terme, Pavone Creek, Roccastrada,

Well to moderately sorted hybrid arenite, crudely bedded, with local plane-parallel stratification and hummocky cross-stratification. Siliciclastic component consists of subangular to subrounded, medium to coarse sand. Carbonate component consists mainly of red algae, bivalve, echinoid, and gastropod fragments,

Amphistegina, and smaller benthic forams. Intergranular spaces are filled with microsparitic cement or finegrained (mostly micritic) matrix.

Poorly to moderately sorted, massive to crudely bedded hybrid arenite. Carbonate component consists of benthic and planktonic forams and fragments of bivalves, echinoids, brachiopods, bryozoans, serpulids, red algae, and barnacles. Siliciclastic component consists of medium sand to pebble-sized lithic clasts and fine- to medium-sand-sized, subangular quartz grains. Locally, grains of glaucony can be common. Intergranular spaces can be rich in fine-grained matrix. Disarticulated ostreid shells, sparse red algal branches, and discontinuous concentrations of brachiopod shells are locally observed.

Similar in texture and composition to facies Hal or Ha2, but occurring in 2-15-cm-thick, foreset beds of clinostratified unit. Beds are generally massive, locally showing erosional base and normal grading, and can display abundant Thalassinoides bioturbation. Montefollonico, Pianosa

Moderately to poorly sorted skeletal packstone (locally wackestone). Bioclasts consist of Amphistegina, smaller benthic forams, echinoid, red algae, mollusk and barnacle fragments, with subordinate planktonic forams, brachiopod, and bryozoan fragments. Bioturbation (Thalassinoides) is common to abundant, but bedding can preserve crude horizontal stratification. Scattered lithic clasts, rhodoliths up to $2 \mathrm{~cm}$ in size, and ostreid and pectinid shells are locally present.
Admixture of terrigenous particles with parautochthonous skeletal production in a moderate-energy setting, with periodic agitation of bottom sediment, close to emerged landmass or fluvial input.

Same as facies Hal, but in a markedly lower-energy setting, characterized by higher rates of bioturbation.

Deposition on clinoform slope, by downwelling flows, of admixture of terrigenous and skeletal particles, followed by intense bioturbation.

Parautochthonous skeletal accumulation in a low-energy setting, with infrequent transport of allochthonous particles during higher energy events and intensely affected by bioturbation. 
TABLE 2.-Continued.

\begin{tabular}{|c|c|c|c|c|}
\hline Category & Facies (with Code) & $\begin{array}{l}\text { Sections where } \\
\text { Facies Occurs }\end{array}$ & Description & Interpretation \\
\hline & $\begin{array}{l}\text { Skeletal packstone to } \\
\text { grainstone in } \\
\text { massive to } \\
\text { bioturbated foreset } \\
\text { beds (Cal2) }\end{array}$ & $\begin{array}{l}\text { Pavone Creek, Bulera, } \\
\text { Poggio del Gallo }\end{array}$ & $\begin{array}{l}\text { Skeletal packstone to grainstone, moderately to poorly } \\
\text { sorted, in } 10-15 \text {-cm-thick foreset beds of clinostratified } \\
\text { unit, with abundant bioturbation ( }>50 \mathrm{~cm} \text { long } \\
\text { Scolicia traces locally visible in planar view). Consists } \\
\text { of echinoid, bivalve, and red algae fragments, benthic } \\
\text { and planktonic forams, and subordinate bryozoan, } \\
\text { serpulid, and barnacle fragments. Intergranular spaces } \\
\text { are filled with micrite or microsparitic cement. }\end{array}$ & $\begin{array}{l}\text { Deposition of skeletal debris by } \\
\text { downwelling flows on the face } \\
\text { of prograding clinoforms } \\
\text { developing just below storm- } \\
\text { wave base, admixed with fine } \\
\text { matrix from suspended load and } \\
\text { micritization by intense } \\
\text { bioturbation. }\end{array}$ \\
\hline & $\begin{array}{l}\text { Skeletal packstone to } \\
\text { grainstone (Cal3) }\end{array}$ & $\begin{array}{l}\text { Casciana Terme, Bulera, } \\
\text { Montegabbro, } \\
\text { Colombaio, Poggio del } \\
\text { Gallo }\end{array}$ & $\begin{array}{l}\text { Skeletal packstone to grainstone, moderately to poorly } \\
\text { sorted, in horizontal beds locally amalgamated. Benthic } \\
\text { forams (including Amphistegina), bivalve, echinoid and } \\
\text { red algae fragments are dominant components, with } \\
\text { bryozoan, barnacle, and serpulid fragments being } \\
\text { subordinate. Skeletal particles are generally randomly } \\
\text { oriented, with local domains showing horizontal } \\
\text { alignment of elongated allochems. Scattered bivalve } \\
\text { shells and red algae branches can also be present. }\end{array}$ & $\begin{array}{l}\text { Parautochthonous to transported } \\
\text { accumulation of skeletal } \\
\text { particles in a moderate-energy } \\
\text { setting, periodically affected by } \\
\text { storm waves. Significant } \\
\text { bioturbation. }\end{array}$ \\
\hline & $\begin{array}{l}\text { Skeletal grainstone to } \\
\text { packstone }(\mathrm{Cal} 4)\end{array}$ & $\begin{array}{l}\text { Casciana Terme, Pavone } \\
\text { Creek, Bulera, } \\
\text { Colombaio, Poggio del } \\
\text { Gallo, Cava Gosti }\end{array}$ & $\begin{array}{l}\text { Skeletal grainstone (locally packstone), moderately to } \\
\text { poorly sorted, with same skeletal components as facies } \\
\text { Cal3, often significantly rounded and abraded. Bedding } \\
\text { is horizontal, crude to well defined, in beds } 5-25 \mathrm{~cm} \\
\text { thick. Traces of bioturbation are sparse to common. }\end{array}$ & $\begin{array}{l}\text { Allochthonous to parautochthonous } \\
\text { accumulation of skeletal } \\
\text { particles in a moderate-energy } \\
\text { setting, close to fair-weather- } \\
\text { wave base. }\end{array}$ \\
\hline
\end{tabular}

Pomarance Unit: Pavone Creek Section.-A composite section, consisting of three juxtaposed segments correlated by lateral tracing of distinctive beds $\left(\log 1: \mathrm{N}^{\circ} 3^{\circ} 15.568^{\prime} \mathrm{E} 10^{\circ} 56.316^{\prime} ; \log 2: \mathrm{N}^{\circ} 3^{\circ} 15.630^{\prime}\right.$ $\mathrm{E} 10^{\circ} 56.305^{\prime} ; \log 3: \mathrm{N} 43^{\circ} 15.669^{\prime} \mathrm{E} 10^{\circ} 56.248^{\prime}$ ), was measured along an $\sim 300 \mathrm{~m}$ long, $\sim \mathrm{N}-\mathrm{S}$-oriented exposure on the left orographic side of the Pavone Creek valley (Figs. 5B, 6A).

The carbonate unit onlaps onto Jurassic bedrock in a northwarddirection, with beds forming an angle of $\sim 8^{\circ}$ against the sloping basal unconformity (Fig. 5B). The basal erosional surface presents some relief and undulations at the meter scale. One of these irregularities, $1.5 \mathrm{~m}$ deep and several meters wide, occurs at the base of the measured section and is filled with breccia deposits of facies $\mathrm{Cg} 2$ (Fig. 6A). The overlying package (3.5 $\mathrm{m}$ thick) has hybrid composition and shows a fining-upward trend (facies $\mathrm{Cg} 1$, Sh1, and Ha2). It is overlain by an $\sim 8.5 \mathrm{~m}$ thick interval of calcarenites (facies Cal1, Cal2) interlayered with finer-grained beds (facies $\mathrm{Ha} 2$ ) and capped by a distinctive, laterally continuous, matrix-rich recessive layer, $40 \mathrm{~cm}$ thick (facies $\mathrm{Fg} 1$ ). The calcarenites are heavily bioturbated, with poorly defined horizontal bedding except for the lowermost calcarenite package $(1.5 \mathrm{~m}$ thick) showing clinostratification dipping to the west. This motif, of bioturbated calcarenite packages (facies Ca14) separated by thinner, matrix-rich, fine grained beds (facies Fg1, Sh3), is repeated three times through the section (Fig. 6A). A crude horizontal bedding characterizes most of the calcarenite packages, with the exception of an $\sim 3.5$-m-thick clinostratified unit at about $30 \mathrm{~m}$ from the base of the section (facies Cal2), with foreset beds indicating progradation in the SW direction. The uppermost $20 \mathrm{~m}$ of the carbonate unit shows a distinct increase in fragments of red algae among the constituent skeletal components. The transition to the overlying upper Argille Azzurre is not preserved at the measured section, but the conformable contact is exposed on the opposite side of the Pavone Creek valley.

Pomarance Unit: Bulera Section.-The basal contact of the unit, estimated to be $\sim 10 \mathrm{~m}$ below the base of the measured section, is not exposed, but mapping indicates that the unit lies on fluvial gravels of an incised-valley fill (Fig. 5A) cut on Pliocene offshore clays. The first measured interval (Fig. 6B) consists of $\sim 3.5 \mathrm{~m}$ of massive hybrid arenite (facies Ha2) passing upward to a 12-m-thick package displaying more defined bedding and low-angle clinostratification $\left(6-8^{\circ}\right)$ in its lowest portion, dipping to the west (facies $\mathrm{Ha} 2$, Ha3). A minor coarseningupwards trend is observed in the top $2 \mathrm{~m}$ of this package. The next interval consists of an $\sim 2.5$-m-thick, laterally continuous, mostly fine-grained unit (facies Fg1, Ha2), characterized by a high content of glaucony, occurrence of articulated bivalve shells, and poorly defined planar bedding. This layer is overlain by a bipartite package, $\sim 7 \mathrm{~m}$ thick, with a lower portion consisting of horizontally bedded hybrid arenite to calcarenite (facies Ha2, Cal3) and an upper portion consisting of a coarsening-upward, clinostratified unit of hybrid arenite to microconglomerate (facies Ha3).

The remainder of the section is characterized by a motif analogous to that seen in the upper part of the Pavone Creek section, with crudely bedded calcarenite packages (Facies Cal3, Cal4), including one interval with low-angle clinostratification (facies $\mathrm{Cal} 2$ ), separated by laterally extensive recessive beds, rich in fine matrix (facies Fg1) (Figs. 5C, 6B). Petrographic analysis of samples from this upper portion of the Bulera section shows a clear decrease in the siliciclastic fraction and a definite increase in red algae fragments among the skeletal components. The top of the section records the conformable transition to the overlying upper Argille Azzurre. The results of magnetobiostratigraphic analyses based mostly on the Bulera section (Tab. 3) indicate the Pomarance unit should be correlated either within Subchron C2An.2n or with the interval between the base of Subchron C2An.1n and the Discoaster tamalis HO (highest occurrence) (Fig. 2).

Pomarance Unit: Stratigraphic Interpretation.-Although located $\sim 3 \mathrm{~km}$ apart, the two sections of the Pomarance area share features indicative of a similar depositional history. These include: a) a general decrease in siliciclastic content from the bottom to the top of the unit (Fig. 6), b) an increase in content of red algae in the upper portion of the unit, c) vertical partition of calcarenite packages separated by laterally continuous fine-grained beds (Figs. 5B, 6), and d) occurrence of packages with clinostratification dipping to the west, consistent with progradation normal to the eastern margin of the Radicondoli-Chiusdino basin. 


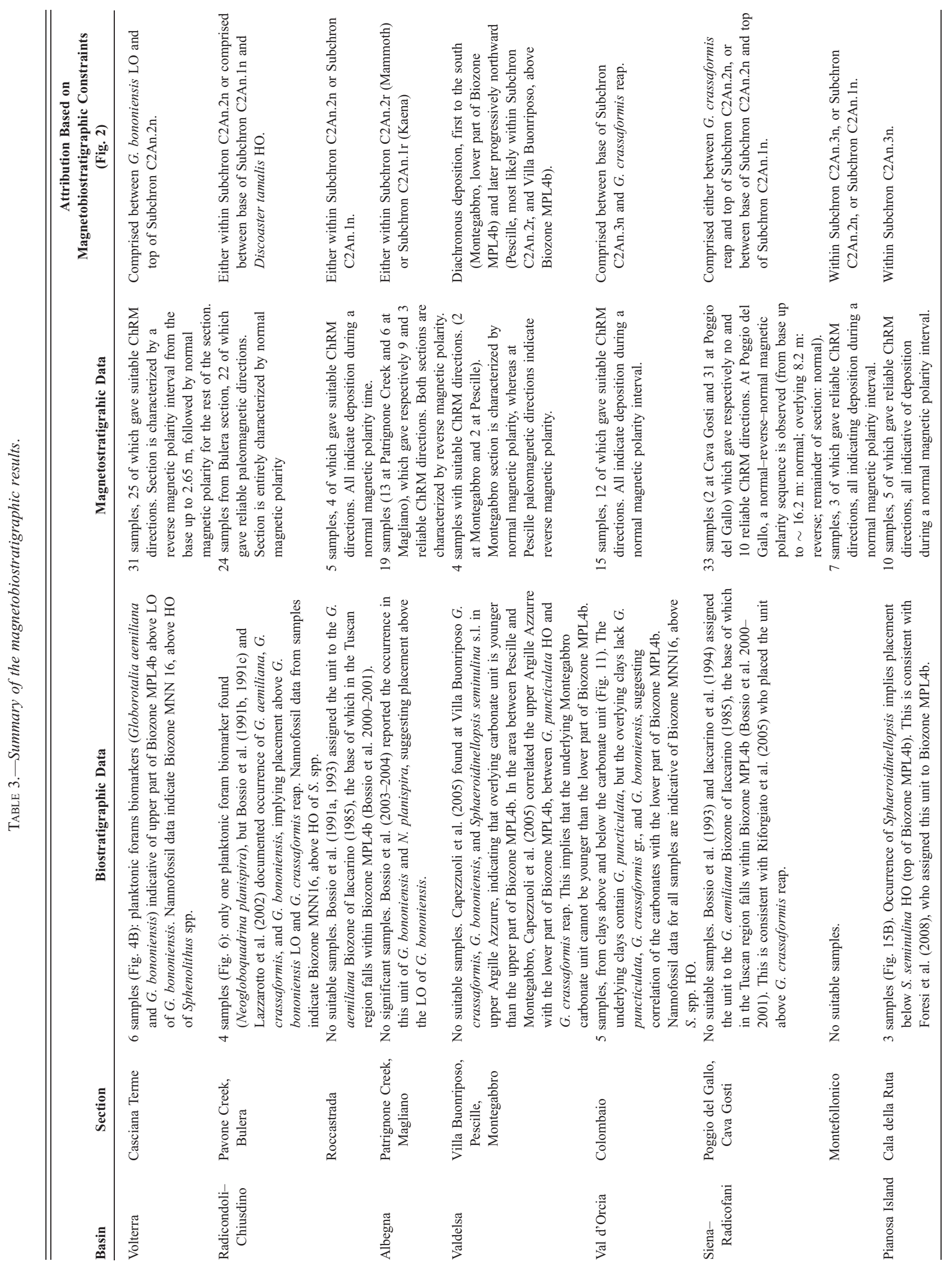




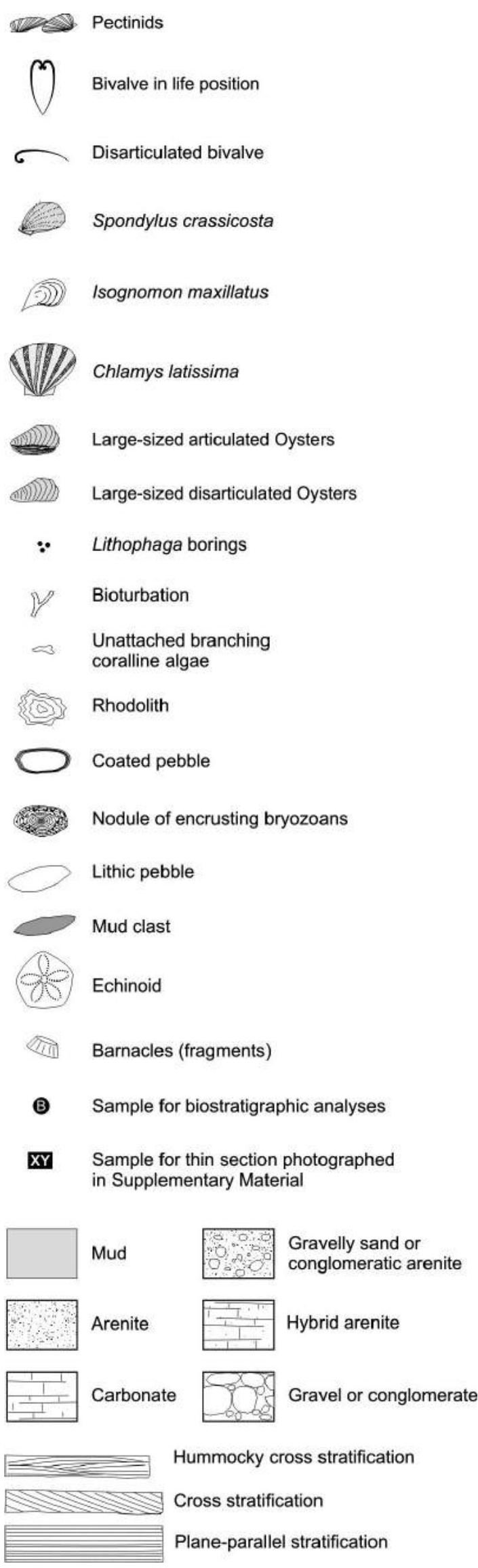

The Pomarance carbonate unit has an unconformable base (well exposed at Pavone Creek), and documents a transgression over a lithologically varied substrate. Upward decrease in siliciclastic content could be related to landward segregation of terrigenous supply during progressive flooding, which eventually led to the demise of the carbonate factory and deposition of the overlying upper Argille Azzurre Fm. Although the carbonate unit as a whole is interpreted to fall within the TST of a sequence, its internal architecture shows a composite organization in at least four and possibly five parasequences, consisting of a lower sharp-based, fine-grained unit passing upward to a coarser-grained package, locally showing evidence of upward coarsening and basinward progradation of clinoforms (Fig. 6). Both allocyclic (e.g., smaller-scale relative sea-level fluctuations) and autocyclic (e.g., changes in productivity of the carbonate factory) processes could be envisaged to account for the origin of these parasequences. The general abundance of fine-grained matrix and bioturbation, combined with the poor to moderate expression of wave- and current-related physical structures, suggest overall deposition of the Pomarance unit in a moderateenergy setting. The higher abundance of hybrid facies at Bulera than at Pavone Creek possibly reflects the proximity of fluvial input and differences in substrate type controlling production of terrigenous detritus upon erosion.

Roccastrada Unit: Description.-A discontinuously exposed carbonate unit is preserved near the town of Roccastrada. The unit lies unconformably on the lower Argille Azzurre Fm., and, locally, Triassic bedrock, and is overlain by Pliocene lacustrine deposits (Bossio et al. 1991a) (Fig. 7). A section measured along a road cut (Fig. 7B) shows the Triassic bedrock unconformably overlain by $\sim 1.5 \mathrm{~m}$ of fining-upward conglomerate (facies $\mathrm{Cg} 1$ ), gradationally overlain by $\sim 2.5 \mathrm{~m}$ of crudely bedded calcarenite rich in red algae (facies Alg1, Cal1). Aside from abundant algal branches and scattered rhodoliths, the carbonate unit contains a subordinate siliciclastic component consisting of very fine to fine angular sand and some dispersed lithic clasts, up to $1 \mathrm{~cm}$ in size. The top of the unit is marked by a sharp contact with the overlying, thinly laminated lacustrine clays, rich in vegetal remains. Magnetobiostratigraphic data (Tab. 3) indicate that the Roccastrada unit falls within either Subchron C2An.2n or Subchron C2An.1n (Fig. 2).

Roccastrada Unit: Stratigraphic Interpretation.-The basal erosional surface is interpreted as a ravinement surface, which is overlain by a transgressive conglomerate. Transition to the overlying unit dominated by red algae is interpreted as documenting the establishment of localized shallow marine carbonate productivity in a low-energy setting, as documented by the scarcity of wave- and current-related physical structures. The nature of the contact with the overlying lacustrine unit is not clear, due to limited outcrop exposure and biostratigraphic control, but it is likely to be unconformable rather than in overall continuity of sedimentation (Bossio et al. 1991a). Considering its position between the basal transgressive conglomerate and a likely capping unconformity, the carbonate unit is thought to have been deposited during transgression and possibly through part of the ensuing regression.

\section{Albegna Basin}

Pliocene carbonates are known from the northwestern sector of the Albegna basin (Fig. 1), near the town of Magliano (Calcareniti di Magliano Fm. of Bossio et al. (2003-2004)). Two sections, located $\sim 1 \mathrm{~km}$ apart, were measured at the Patrignone Creek and at the town of Magliano (Figs. 8A, 9).

FIG. 3.-Explanation of symbols used in the stratigraphic logs of Figures 4, 6, 7, 9-15. 
Magliano Unit: Patrignone Creek Section.-The base of the measured section (Fig. 9A) consists of a sharp, planar contact (Fig. 8B) between the carbonate unit and underlying clays of the lower Argille Azzurre Fm. Postdepositional disruption of the original surface is locally observed, with the clays protruding upward for about $1 \mathrm{~m}$, truncating and deforming the lowermost layers of the carbonate unit (Fig. 8C).

The first measured interval (Fig. 9A) consists of $\sim 1.5 \mathrm{~m}$ of hybrid arenite (Facies Ha1) in massive to planar-laminated beds, interspersed with thin, less than $5-\mathrm{cm}$-thick mud layers which are laterally discontinuous or transition to mud clasts levels. This unit is overlain by a thinly laminated, 20 -cm-thick, mud layer rich in vegetal remains. The next interval consists of $\sim 50 \mathrm{~cm}$ of hummocky cross-stratified hybrid arenite (facies Ha1), overlain by a 50 -cm-thick package of plane-parallel-stratified hybrid arenites. This package constitutes the bottomsets of a clinoformed body, of which at least $6 \mathrm{~m}$ are preserved in this section. The foreset beds of the clinoformed body are $2-10 \mathrm{~cm}$ thick, generally massive but with some plane-parallel stratification and rare examples of normal grading. Bioturbation can be observed in some of the beds. Thin, discontinuous mud drapes can also be present. The clinoformed unit is composed mostly of hybrid arenite and Amphistegina-rich calcarenite (facies Ha3, Amph1). The foresets dip ESE, with an average inclination of $10-15^{\circ}$. The top of this unit corresponds to the present topographic surface.

Magliano Unit: Magliano Section.-At the town of Magliano, the basal portion of the carbonate unit, including the contact with the substrate, is not exposed. Bedding along the outcrop dips ESE, with an inclination of $15-20^{\circ}$. The section consists of three segments, a few meters apart, directly correlated along inclined stratal surfaces (Fig. 8D). The lower and more proximal segment (Fig. 9B) consists of an alternation of rudstone and grainstone beds rich in red algae (facies Alg3) partially amalgamated in the lower meter and more distinctly bedded in the upper part. This characteristic alternation of coarser and finer beds $(5-15 \mathrm{~cm}$ thick on average $)$ is observed throughout the entire second measured segment $(\sim 4$ $\mathrm{m}$ thick) (Fig. 9C). Rudstone beds can be characterized by openwork texture, an erosional base, and normal grading. The uppermost and more distal segment (Fig. 9D) shows a sharp transition from the grainstone to rudstone beds to an $\sim 3$-m-thick package of intensely bioturbated hybrid arenite (facies Ha3), overlain in turn by an $\sim 2$-m-thick bed dominated by red algae (facies Alg1). The bed presents a denser interlocking of algal branches in its lower part and a looser arrangement in the upper part. Above this bed, lies another package, at least $3 \mathrm{~m}$ thick, of highly bioturbated hybrid arenite (facies Ha3), and the top of the succession corresponds to the present topographic surface. Magnetobiostratigraphic data based on both the Magliano and Patrignone Creek sections (Table 3) indicate that the Magliano unit falls within either Subchron C2An.2r (Mammoth) or Subchron C2An.1r (Kaena) (Fig. 2).

Magliano Unit: Stratigraphic Interpretation.-The carbonate unit is located on the northern margin of the Albegna basin, which has a general orientation trending NE (Fig. 1A), roughly normal to the NW-SE alignment of the two measured sections (Fig. 9A). This implies that the Patrignone Creek section is located more basinward than the Magliano section. The direction of progradation of the Patrignone Creek clinoformed unit (ESE) is also normal and oriented away from the basin margin.

The basal surface of the carbonate unit (exposed only at the Patrignone Creek section) is interpreted as a ravinement surface eroding older Pliocene clays. The example of soft-sediment deformation observed along the contact implies localized plasticity and water impregnation of the clays after deposition of the basal portion of the carbonate unit, with further deformation possibly related to differential compaction. The basal hybrid arenite is interpreted as part of the transgressive systems tract (TST), with a suggested maximum flooding surface located within the overlying $20-\mathrm{cm}$ thick fine layer. The rest of the section is thought to represent part of the highstand systems tract (HST), with a progradational trend well documented by the clinoformed unit. The succession at the Magliano section shows inclined stratification dipping in a direction similar to that of the Patrignone Creek clinoformed unit, and facies (Alg3) indicative of avalanching processes on an inclined depositional face. Possibly, the Magliano outcrop correlates with the clinoformed unit at Patrignone Creek, with both sites preserving exposures of the same prograding clinoformed body. Both sections display a relatively high siliciclastic content throughout, possibly related to fluvial sediment discharge at the basin margin.

\section{Valdelsa Basin}

Pliocene carbonates are known from the southwestern margin of the Valdelsa basin (Fig. 1), where they are exposed in the Villa Buonriposo area, near the town of Montegabbro, and in small scattered outcrops between these two sites (Fig. 10A). The carbonates at Villa Buonriposo were studied in detail by Capezzuoli et al. (2006), and a summary of their results is included in Table 1. South of Villa Buonriposo, in the Pescille area $\left(\mathrm{N} 43^{\circ} 26.899^{\prime} \mathrm{E} 11^{\circ} 01.212^{\prime}\right)$, a veneer of calcarenites ( $<2 \mathrm{~m}$ thick) rich in skeletal fragments is observed to rest unconformably over Miocene deposits and Triassic bedrock. Detailed stratigraphic and sedimentologic analysis was not performed for this outcrop because of its limited thickness, but some samples were analyzed for magnetostratigraphic purposes. Farther south, a section was measured near the town of Montegabbro (Fig. 10B, C), where a small carbonate unit of limited areal extent is preserved.

Montegabbro Section: Description.-The base of the section corresponds to an erosional contact with Triassic bedrock. The basal unconformity is overlain by a conglomerate unit ( $\sim 1.5 \mathrm{~m}$ thick) with bored lithic clasts up to $40 \mathrm{~cm}$ in size and common ostreid shells in its upper part (facies $\mathrm{Cg} 1$ ). The conglomerate is overlain by a massive calcarenite, rich in red algae fragments, which grades upward into an $\sim 1.5$-m-thick bed dominated by red algae (facies Alg1). The bed contains algal branches densely packed in a chalky micritic matrix, subspherical to ellipsoidal rhodoliths up to $5 \mathrm{~cm}$ in size, and fragments of barnacle and ostreid shells as well as isolated clasts of substrate. The top of this bed is characterized by the occurrence of several ellipsoidal nodules (up to $8 \mathrm{~cm}$ in size) consisting almost entirely of membraniporifom encrusting bryozoans. The bed is gradationally overlain by $\sim 1.5 \mathrm{~m}$ of massive calcarenite (facies $\mathrm{Cal} 3$ ), which grades to the top of the section into a coarse hybrid arenite (facies Ha1). The transition to the overlying upper Argille Azzurre is not observed at this site but can be deduced from field mapping relationships (Fig. 10B). Magnetobiostratigraphic data from Montegabbro and other localities on the western margin of the Valdelsa basin (Tab. 3) indicate that Pliocene carbonate deposition occurred diachronously, first to the south (Montegabbro, lower part of Subzone MPL4b) and later progressively northward (Pescille, most likely within Subchron C2An.2r, and Villa Buonriposo, above Subzone MPL4b) (Fig. 2).

Valdelsa Carbonate Units: Stratigraphic Interpretation.-The carbonate units which developed on the southwestern margin of the Valdelsa basin share common attributes such as small areal extent, lateral interfingering with more terrigenous deposits, and general absence of physical sedimentary structures. Together, they are interpreted as documenting localized carbonate productivity in shallow waters, in moderate- to low-energy settings influenced by relatively high siliciclastic input. Interestingly, formation of large-sized bryozoan nodules as those found in the Montegrabbro section has also been associated with carbonate shoals in areas of high terrigenous discharge (Moissette et al. 2010). An 

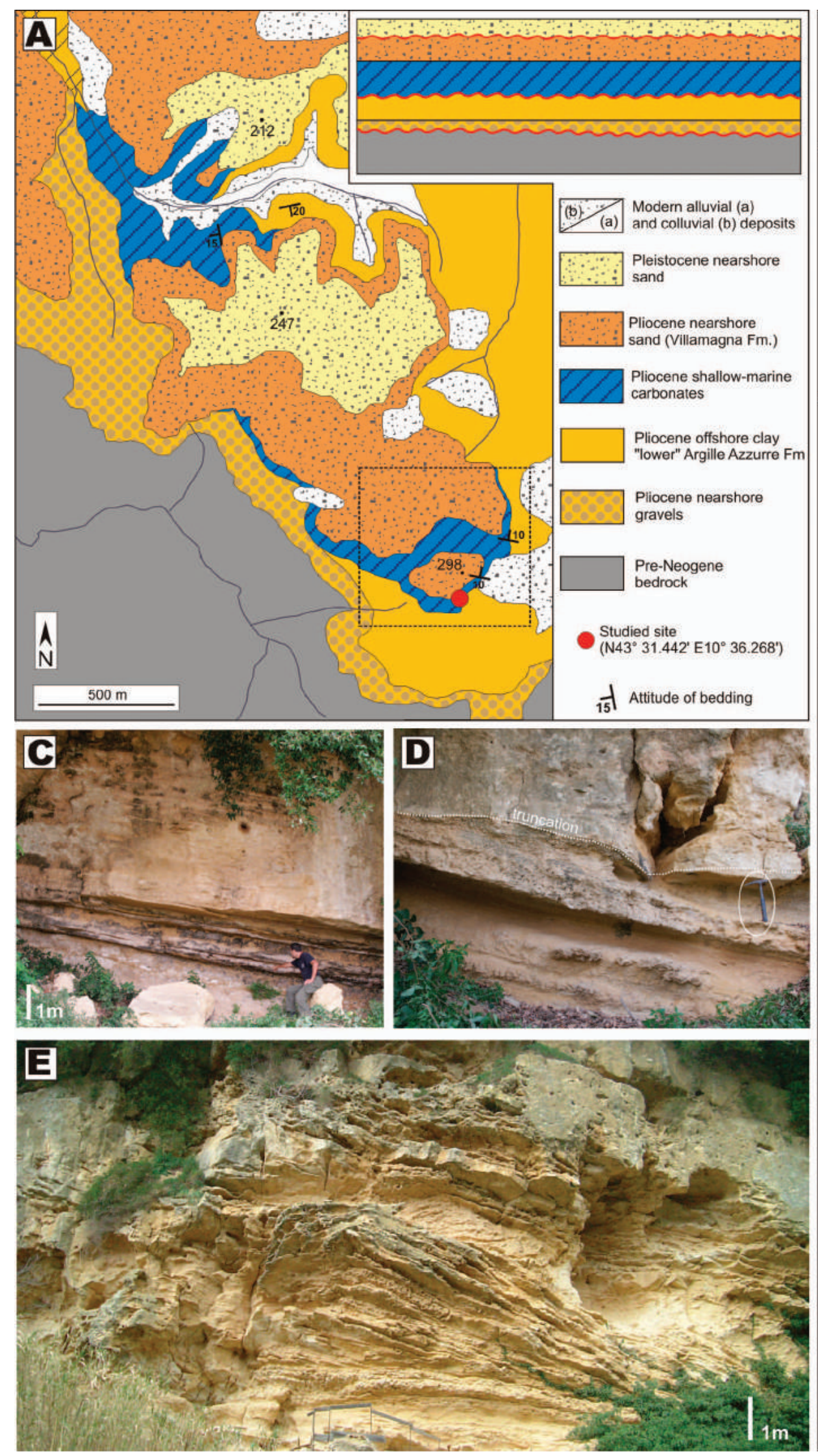

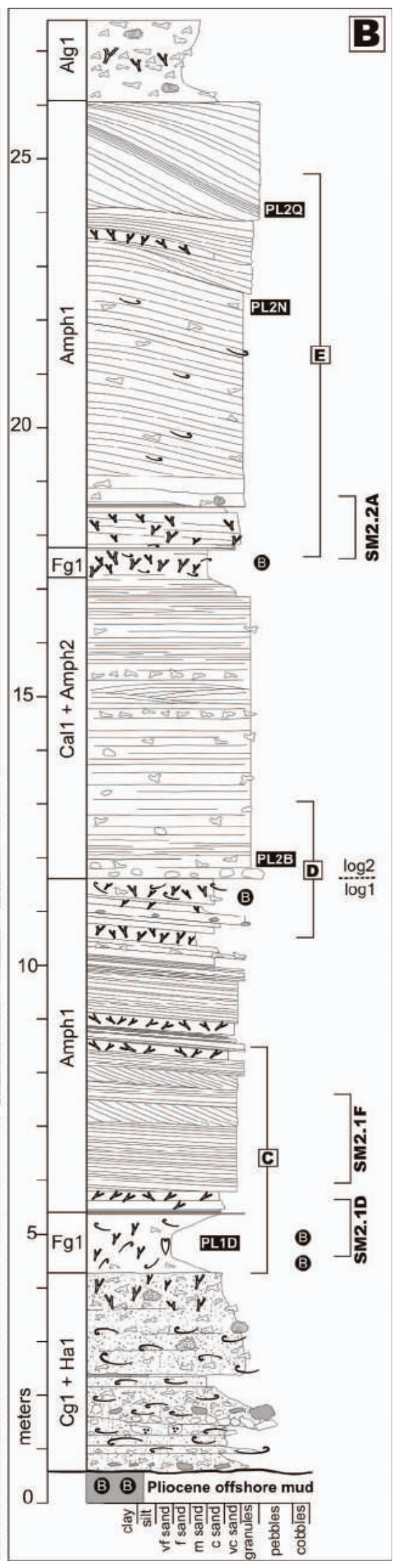




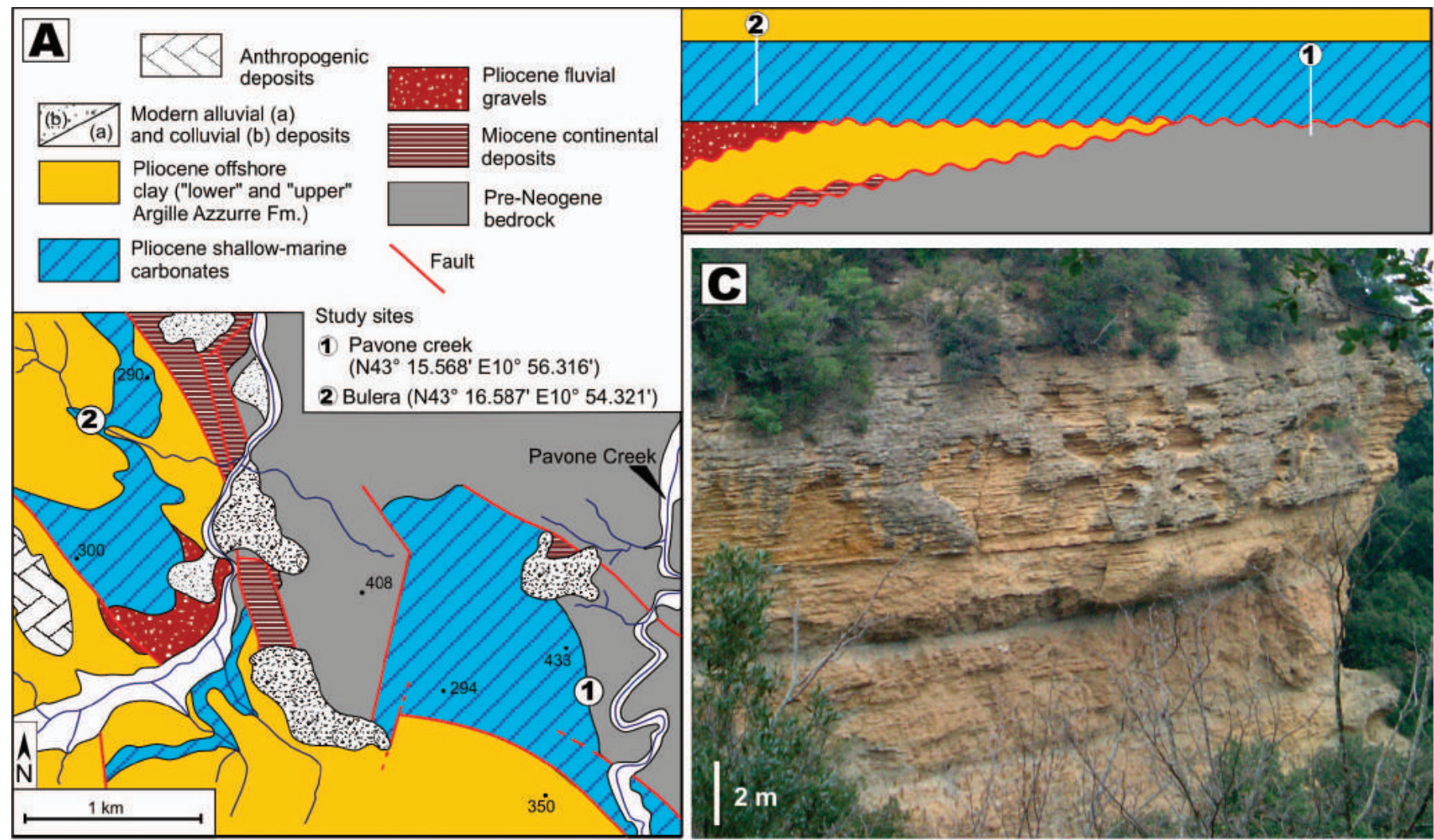

B

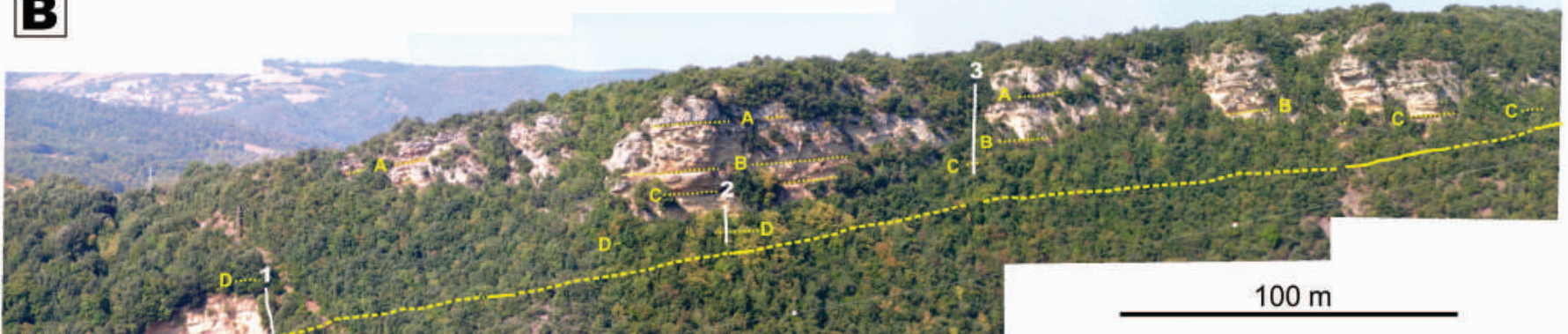

FIG. 5.- The Pomarance carbonate unit. A) Geologic map of the Pomarance area (see Fig. 1B for location), with indication of the studied localities and scheme of the vertical relationship of the lithostratigraphic units (top right inset) showing the intervals measured in the sections (Fig. 6). B) The Pavone Creek outcrop, showing onlap of the carbonate unit directly over pre-Neogene bedrock. The thicker line indicates the basal contact with the substrate, and the thinner lines indicate laterally continuous, finegrained marker beds (lettered for ease of lateral correlation) within the carbonate unit. The vertical traces of the measured logs (numbered 1 to 3 ) used to construct the composite section of Figure 6A are also indicated. C) Calcarenite packages at Bulera section (see Fig. 6B for position of the illustrated interval) separated by finer-grained, recessive beds.

important difference in the stratigraphic interpretation of the individual units concerns their relationship with the upper Argille Azzurre Fm. At Montegabbro the carbonates lie directly above the bedrock and are overlain by the upper Argille Azzurre (Fig. 10B), indicating development in an overall transgressive trend. In contrast, the carbonates at Villa Buonriposo overlie the upper Argille Azzurre Fm. and developed in the final regressive stage of the Piacenzian flooding of the Valdelsa basin (Capezzuoli et al. 2005), in the marginal areas of the basin.

FIG. 4.- The Casciana Terme carbonate unit. A) Geologic map of the Casciana Terme area (see Fig. 1B for location). Rectangle indicates the Parlascio area, where the composite log shown in Part B was measured. Inset to the top right schematically illustrates the vertical stratigraphic relationship of the units present in this area. B) Composite $\log$ of the Casciana Terme section. Facies codes to the left of the log are explained in Table 2. Brackets to the right of the log indicate intervals illustrated in other insets of the figure and in the Supplementary Material. C) Coarsening-upward transition from a fine-grained skeletal packstone bed overlain by a several-meters-thick, Amphisteginadominated, clinostratified body. D) View of the slightly irregular truncation surface at the top of the clinostratified body partly shown in part C. E) The composite nature of the upper clinostratified body. Note set at center of picture with different dip direction, possibly indicative of backset stratification or lateral onlap of adjacent lobes on the face of a prograding clinoform front. 

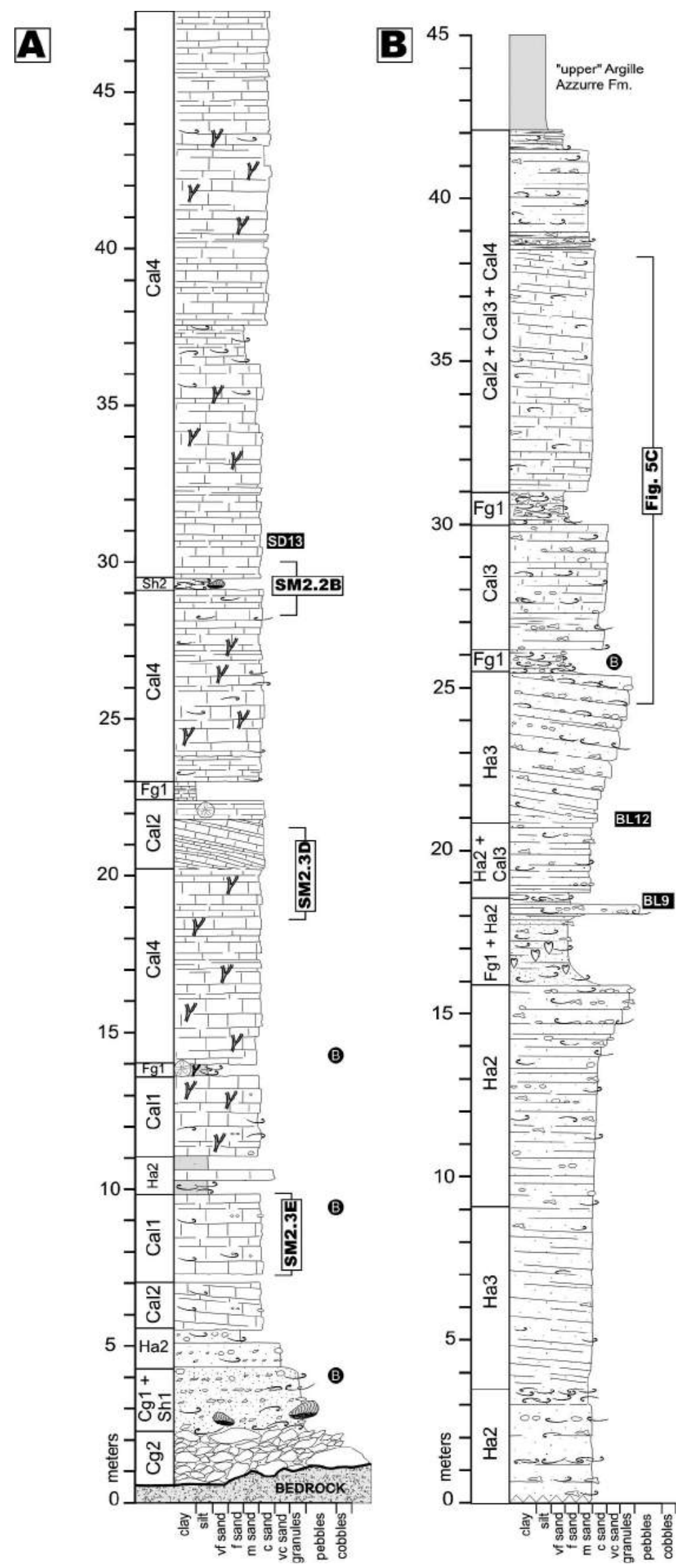

Fig. 6.-Stratigraphic logs of the sections measured in the Pomarance area (see Fig. 5A for their exact location). Facies codes to the left of the logs are explained in Table 2. Brackets to the right of the logs indicate intervals illustrated in Figure 5 and in the Supplementary Material. A) Pavone Creek composite section. B) Bulera section. 

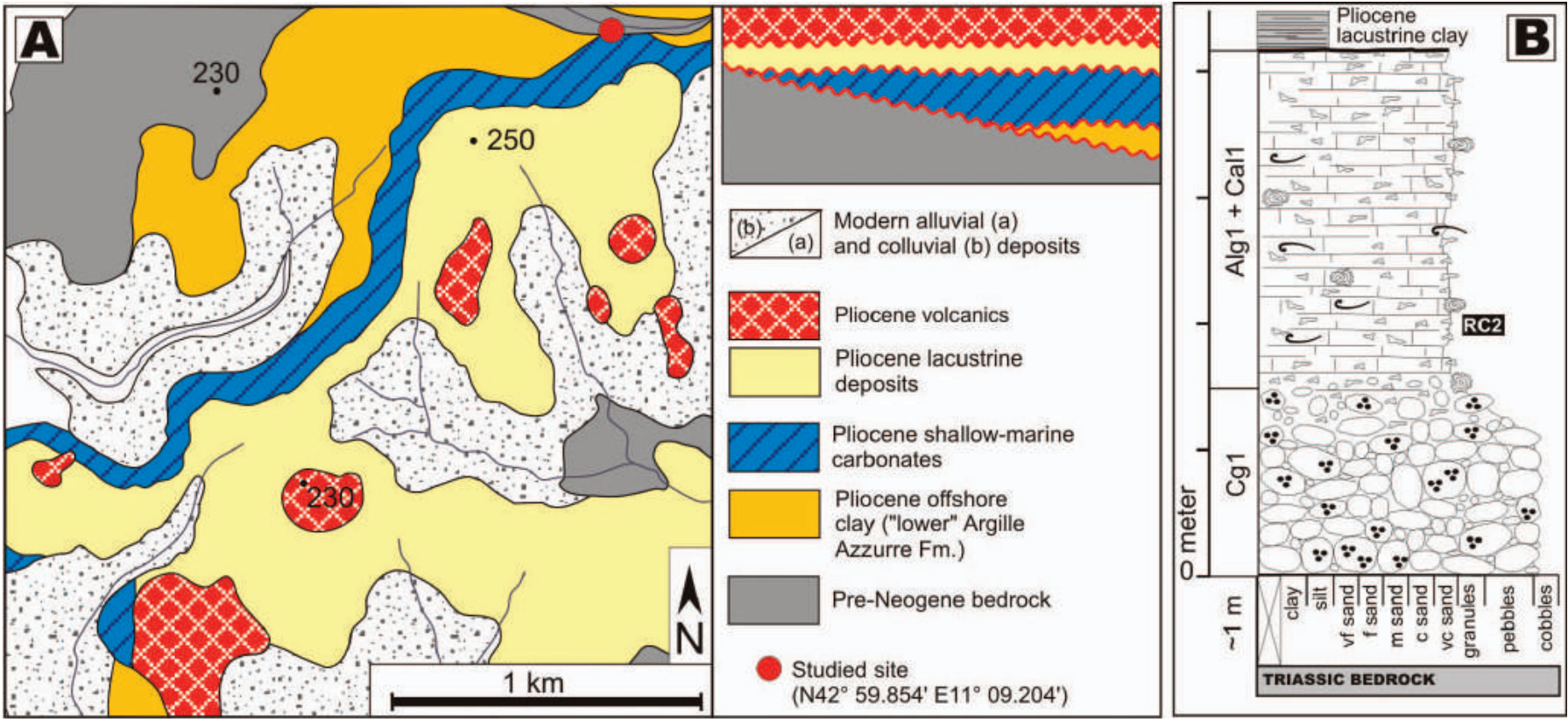

FIG. 7.- The Roccastrada carbonate unit. A) Geologic map of the Roccastrada area (see Fig. 1B for location), with a schematic of the vertical relationship of the lithostratigraphic units (top right inset). B) Stratigraphic log of the Roccastrada section. Facies codes to the left of the log are explained in Table 2.

\section{Val d'Orcia Basin}

Pliocene carbonates from the Val d'Orcia basin (Fig. 11A) were analyzed in detail by Nalin et al. (2010). Their results are summarized in Table 1 and briefly described below.

Two carbonate outcrops of small areal extent (Colombaio and Sassi Neri localities) are known from the northeastern margin of the basin (Fig. 1). They consist of crudely bedded, tabular accumulations of rudstone, floatstone, and packstone rich in red algae, with high degree of bioturbation and poor development of physical sedimentary structures (Fig. 11B, C). The carbonates lie unconformably over the lower Argille Azzurre Fm. and are gradationally overlain by the upper Argille Azzurre Fm. Nalin et al. (2010) interpreted the carbonate deposits as developed during transgression in a sheltered coastal embayment experiencing moderate-energy conditions. New magnetobiostratigraphic data obtained for this study (Table 3) indicate that the carbonates correlate with the interval between the base of Subchron C2An.3n and the G. crassaformis reappearance biohorizon (Fig. 2).

\section{Siena-Radicofani Basin}

Pliocene carbonates are preserved on the eastern margin of the SienaRadicofani basin, along the flanks of the Cetona ridge and near the town of Montefollonico (Fig. 1). The carbonates surrounding the Cetona ridge are volumetrically significant, and some isolated outcrops have been described by Iaccarino et al. (1994), Liotta (1996), and Checconi et al. (2007). In this study, two sections (Poggio del Gallo and Cava Gosti) were measured from the northwestern sector of the ridge, respectively in a distal and proximal position from the core of the Cetona ridge. The carbonate unit at Montefollonico is of relatively small areal extent and is found at the top and northwestern flank of an isolated hill, where a section was also measured.

Cetona Unit: Poggio del Gallo Section.-The carbonate unit at Poggio del Gallo rests partly on pre-Neogene bedrock and partly on sands and clays (lower Argille Azzurre) of an older Pliocene sequence. A composite section was measured (Fig. 12B), consisting of two separate logs, $\sim 70 \mathrm{~m}$ apart $\left(\log 1: \mathrm{N}^{\circ} 3^{\circ} 00.049^{\prime} \mathrm{E} 11^{\circ} 49.547^{\prime} ; \log 2: \mathrm{N} 43^{\circ} 00.032^{\prime} \mathrm{E} 11^{\circ}\right.$ $\left.49.501^{\prime}\right)$. The contact with the substrate is not exposed and is estimated to lie a few meters below the base of the section. Overall, the beds show low inclination $\left(\sim 10^{\circ}\right)$ to the $\mathrm{WNW}$, but it is not possible to determine if this represents an original clinostratification or postdepositional tilting of the strata.

The lowermost $5 \mathrm{~m}$ of the measured section consist of amalgamated calcarenite rich in red algae (facies Alg2), overlain by $\sim 6 \mathrm{~m}$ of bioturbated and crudely bedded calcarenite interspersed with several pectinid shellbeds (facies Sh3) and some rhodolith and layers rich in red algae. Red algae are also the dominant component in the overlying $5 \mathrm{~m}$ of the succession (facies Alg1). These are in turn overlain by $\sim 4 \mathrm{~m}$ of calcarenite with several interspersed pectinid and ostreid shellbeds (facies Sh3). The next interval ( $\sim 5 \mathrm{~m}$ thick) consists of $15-50-\mathrm{cm}$-thick, massive calcarenite and beds rich in red algae (facies Alg1, Alg2). This package is overlain by a clinostratified unit (Fig. 12C), $2.5 \mathrm{~m}$ thick, filling an erosional trough with a lateral extent of $\sim 20 \mathrm{~m}$ and an axis oriented roughly NW-SE. The succession is capped by $\sim 2.5 \mathrm{~m}$ of crudely bedded calcarenite (facies Alg2). Magnetobiostratigraphic data (Table 3) indicate that the Cetona unit falls within an interval either between $G$. crassaformis reap. and the top of Subchron C2An.2n, or between the base of Subchron C2An.2n and the top of Subchron C2An.1n (Fig. 2).

Cetona Unit: Cava Gosti Section.- This section is located on the face of a quarry $\left(\mathrm{N} 42^{\circ} 58.144^{\prime} \mathrm{E} 11^{\circ} 51.899^{\prime}\right)$ where the contact with Mesozoic basement rocks and the overlying carbonate unit is well exposed (Fig. 13A, B). The contact is a planar angular unconformity, sloping at a low angle (3$4^{\circ}$ ), directly onlapped by an $\sim 2$-m-thick breccia and conglomerate unit (facies $\mathrm{Cg} 1, \mathrm{Cg} 2$ ). This basal, coarse-grained interval is massive and consists of calcareous lithic clasts (up to $1 \mathrm{~m}$ in size) eroded from the substrate and often heavily bored and coated by a veneer of calcareous red algae. The breccia facies $(\mathrm{Cg} 2)$ is observed only at the very contact with the substrate, whereas clasts are generally subrounded moving away from the contact. The matrix of the conglomerate is fine-grained. The upper part of this coarsegrained package is characterized by the occurrence of some irregularly shaped pockets (up to $1 \mathrm{~m}$ in size) filled mostly by fine-grained calcareous 

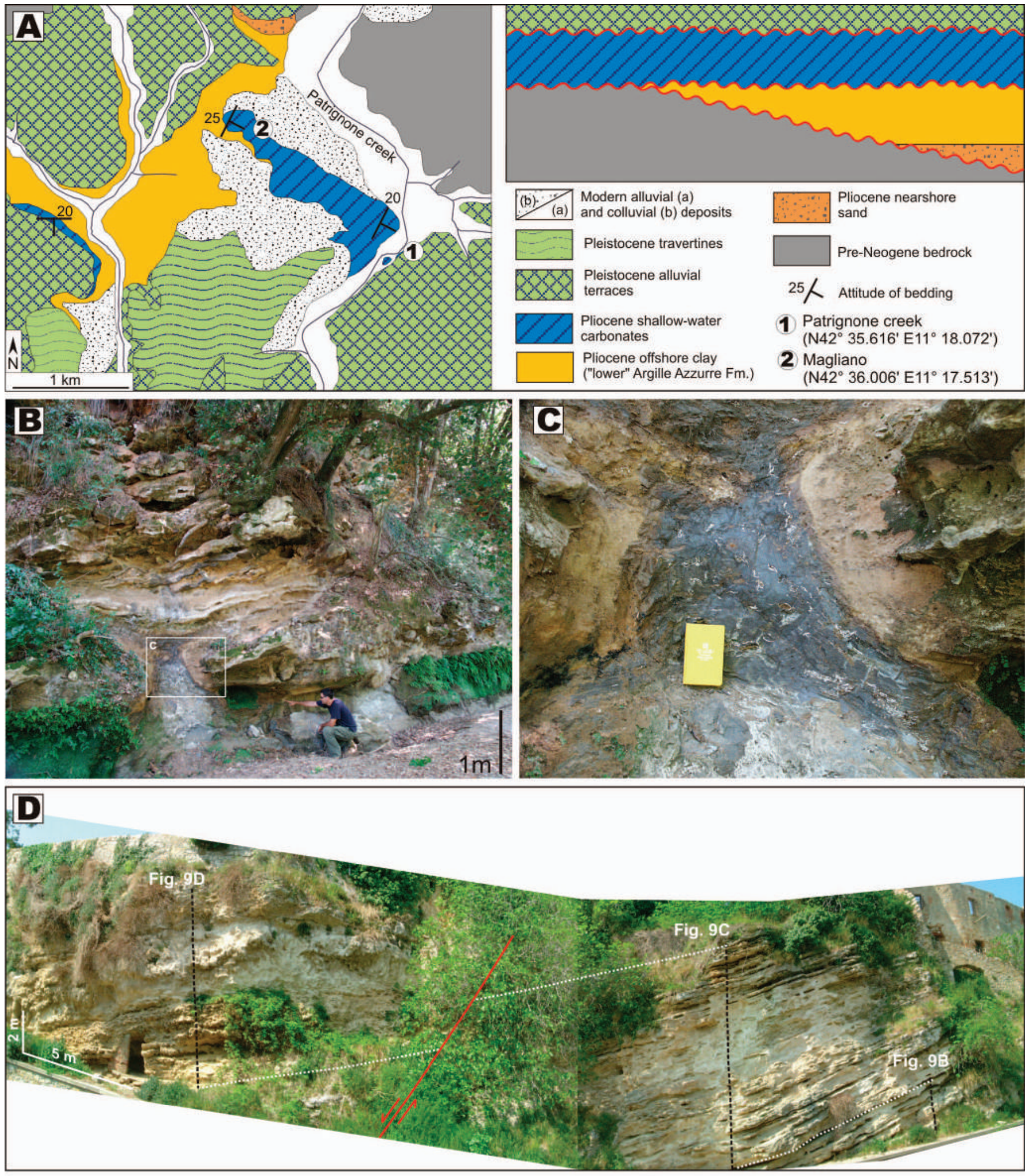

FIG. 8. - The Magliano carbonate unit. A) Geologic map of the Magliano area (see Fig. 1B for location), with indication of the studied localities and scheme of the vertical relationship of the lithostratigraphic units (top right inset). B) The contact (indicated by person in the photo) between the carbonate unit and the underlying lower Argille Azzurre Fm. Rectangle indicates area enlarged in Part C. C) Detail of post-depositional soft-sediment deformation observed along the basal contact of the carbonate unit, with underlying clays protruding upward and truncating hybrid arenite deposits. Long side of notebook for scale is $19 \mathrm{~cm}$ long. D) View of the Magliano section outcrop, with traces of the three measured logs represented in Figure 9. A small normal fault (center picture) offsets the outcrop. 

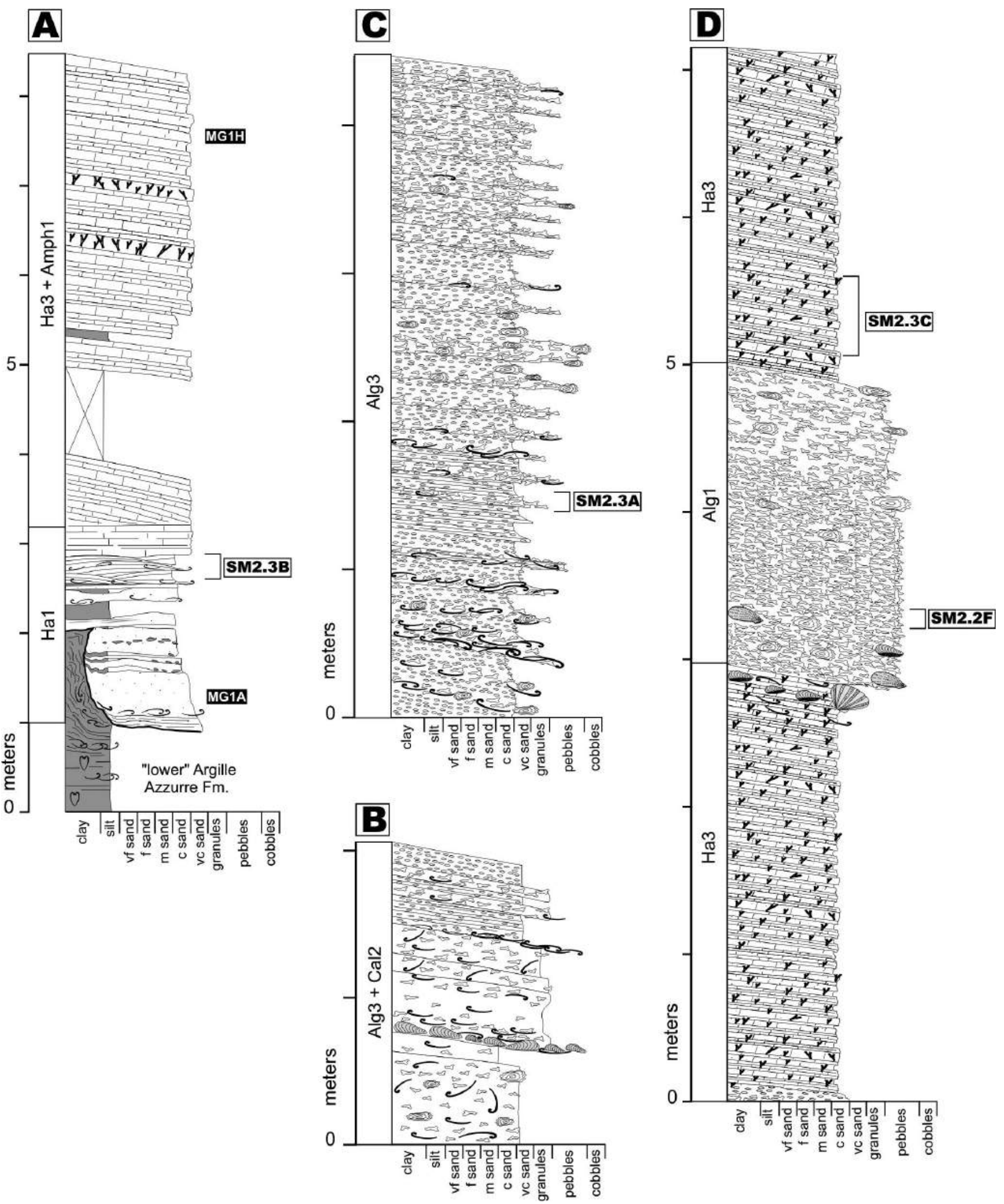

Fig. 9. - Stratigraphic logs of the sections measured in the Magliano area (see Fig. 8A for their exact location). Facies codes to the left of the logs are explained in Table 2. Brackets to the right of the logs indicate intervals illustrated in the Supplemental Material. A) Patrignone Creek section. B, C, D) Magliano section. 


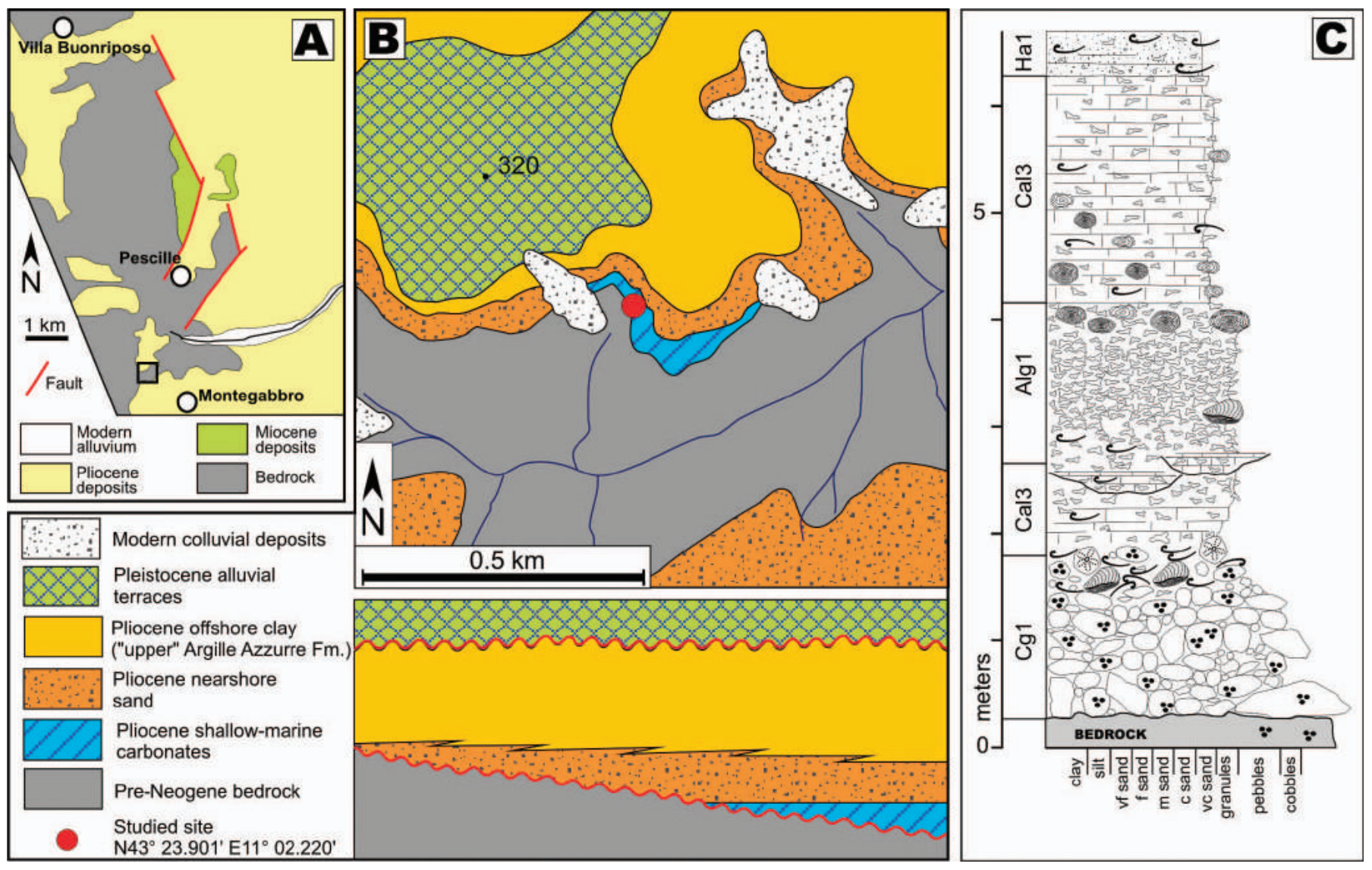

FIg. 10. - Carbonate units in the Valdelsa basin. A) Schematic geologic map of the southwestern part of the Valdelsa basin (see Fig. 1B for location), with localities mentioned in this study. Rectangle indicates area enlarged in Part B. B) Geologic map of the Montegabbro area, with a scheme of the vertical relationship of the lithostratigraphic units (bottom right inset). C) Stratigraphic log of the Montegabbro section. Facies codes to the left of the logs are explained in Table 2.

sediment, often with festoon and wavy lamination, and by some sparse, normally graded microconglomeratic beds up to $3 \mathrm{~cm}$ thick (Fig. 13C).

The basal conglomerate grades upward quite abruptly into a massive calcarenite (facies Cal4) $7.5 \mathrm{~m}$ thick. Several thin $(<10 \mathrm{~cm}$ ), laterally discontinuous layers rich in pebble-size bedrock clasts (often coated by a thin veneer of red algae) and rhodoliths up to $6 \mathrm{~cm}$ in size are interspersed within the calcarenite (Fig. 13D). The top of the calcarenite correspond to the present topographic surface.

Cetona Unit: Stratigraphic Interpretation.-The Poggio del Gallo and Cava Gosti sections record shallow marine sedimentation at the northern margin of an elongated island (Checconi et al. 2007). At Cava Gosti, the coarse-grained basal transgressive deposits attest to the proximity of the eroding emerged substrate and limited reworking during transgression. The fine-grained, matrix-rich pockets at the top of the conglomerate represent the infill of spaces between larger blocks. The fact that these fines were not winnowed away suggests rapid accumulation and a moderate-energy regime even at this proximal location. The abundance of bedrock clasts in the overlying calcarenite and interspersed conglomerate layers implies offshore transport of detritus from the calcareous basement, linked to episodic higher-energy events.

At Poggio del Gallo, the basal transgressive deposits are not exposed and the measured succession is interpreted as recording highstand sedimentation. Salient features of the section include dominance of red algae (with several maërl beds) and numerous interspersed bivalve shell concentrations (mostly pectinids and ostreids). Bedding varies from amalgamated to distinct, but bioturbation appears ubiquitous. Facies point to a depositional environment above storm-wave base but below fairweather-wave base, with offshore transport of bioclasts during higherenergy events and abundant bioturbation in the intervening times. Even though mixing and transport of bioclasts appear predominant, part of the assemblage is thought to reflect parautochthonous productivity of a carbonate factory dominated by red algae and bivalves. The erosional trough observed in the top part of the succession could represent a channelized form eroded by currents during a higher-energy storm, later infilled during offshore-directed transport of skeletal particles.

Montefollonico Section: Description.-The carbonate deposits onlap the substrate (Fig. 14A). The section was measured on the hillside (Fig. 14B), but additional samples for thin-section analysis and magnetostratigraphy were taken from outcrops at the hilltop. The base of the unit consists of a sharp erosional surface, truncating a succession of shoreface sands belonging to an older Pliocene sequence (Fig. 14C). The basal contact is overlain by $\sim 1 \mathrm{~m}$ of normally graded conglomerate (facies $\mathrm{Cg} 1$ ) with well rounded, bored, lithic clasts. The conglomerate grades into $\sim 1.3$ $\mathrm{m}$ of hybrid arenite, with dispersed lithic pebbles, rhodoliths up to $3 \mathrm{~cm}$ in size, and common barnacle and bivalve shells. The remainder of the section $(\sim 4.5 \mathrm{~m})$ is characterized by a lower terrigenous content, and consists of massive to crudely bedded, matrix-rich calcarenites (facies Cal1) with several intervals rich in small rhodoliths (up to $3 \mathrm{~cm}$ in size), unattached red algal branches, and whole or fragmented shells of barnacles. Red algae and barnacles are often found in association, encrusting each other. Bivalve and gastropod shells and fragments are also abundant. Samples taken from outcrops at the hilltop are dominated by 

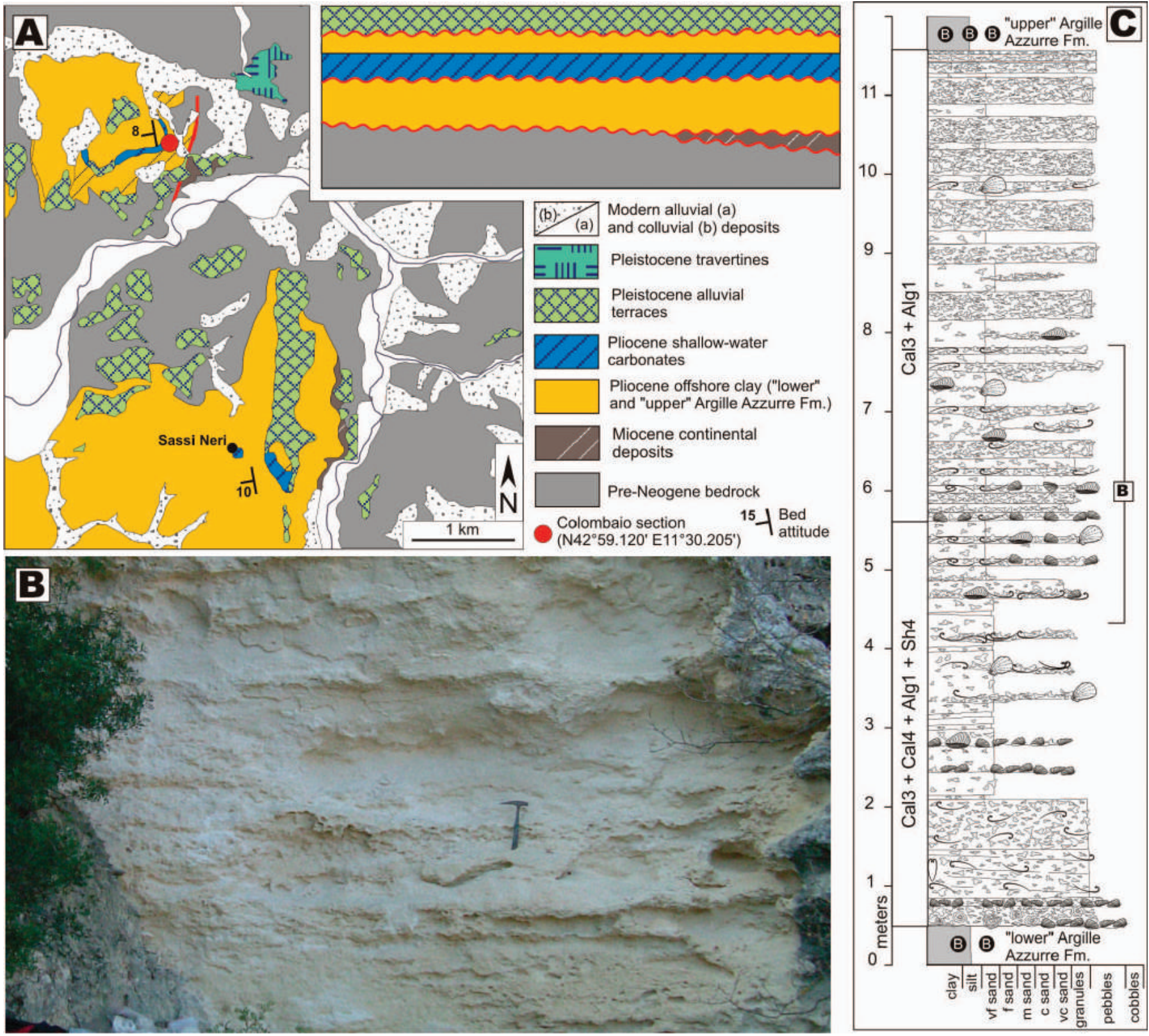

FIG. 11.-Carbonate units in the Val d'Orcia basin. A) Geologic map of the eastern part of the Val d'Orcia basin. Top right inset shows the vertical relationship of the lithostratigraphic units. B) Irregular bedding and bioturbation as visible in the Colombaio section. Hammer for scale is $33 \mathrm{~cm}$ long. C) Stratigraphic log of the Colombaio section (after Nalin et al. 2010). Facies codes to the left of the logs are explained in Table 2. Bracket to the right of the log indicates interval illustrated in Part B.

unattached branches of red algae in a bioclastic packstone matrix (Facies Alg1). Only magnetostratigraphic data are available for this location (Tab. 3), leaving chronostratigraphic attribution somehow ambiguous. Assuming broad correlation with the neighboring Cetona unit, the Montefollonico unit could be correlated with Subchron C2An.2n or Subchron C2An.1n, although deposition during Subchron C2An.3n cannot be excluded (Fig. 2).

Montefollonico Section: Stratigraphic Interpretation.-The hill at Montefollonico represents an isolated structural high of Mesozoic bedrock that was submerged at least twice during the Pliocene. Nearshore sands of a first Pliocene cycle are preserved at lower elevation and are erosionally truncated by the younger carbonate unit (Fig. 14A). The basal contact of the measured section is interpreted as a ravinement surface overlain by a basal transgressive conglomerate. The transgressive pulse documented by the carbonate unit fully flooded the basement island, as seen by onlap of the carbonates and direct superposition over the basement at the hilltop. The upward-decreasing trend in terrigenous content observed in the measured section could be linked to the progressively smaller area of exposed landmass as transgression proceeded. The scarcity of wave- and current-related physical structures and the poor sorting and high matrix content of the calcarenite point to a low-energy hydrodynamic setting during deposition of most of this unit. No other unit is preserved in the area above the carbonate deposits. Possibly, the upper portion of the Montefollonico unit records highstand conditions preceding regional uplift and emergence of the basin margin. 

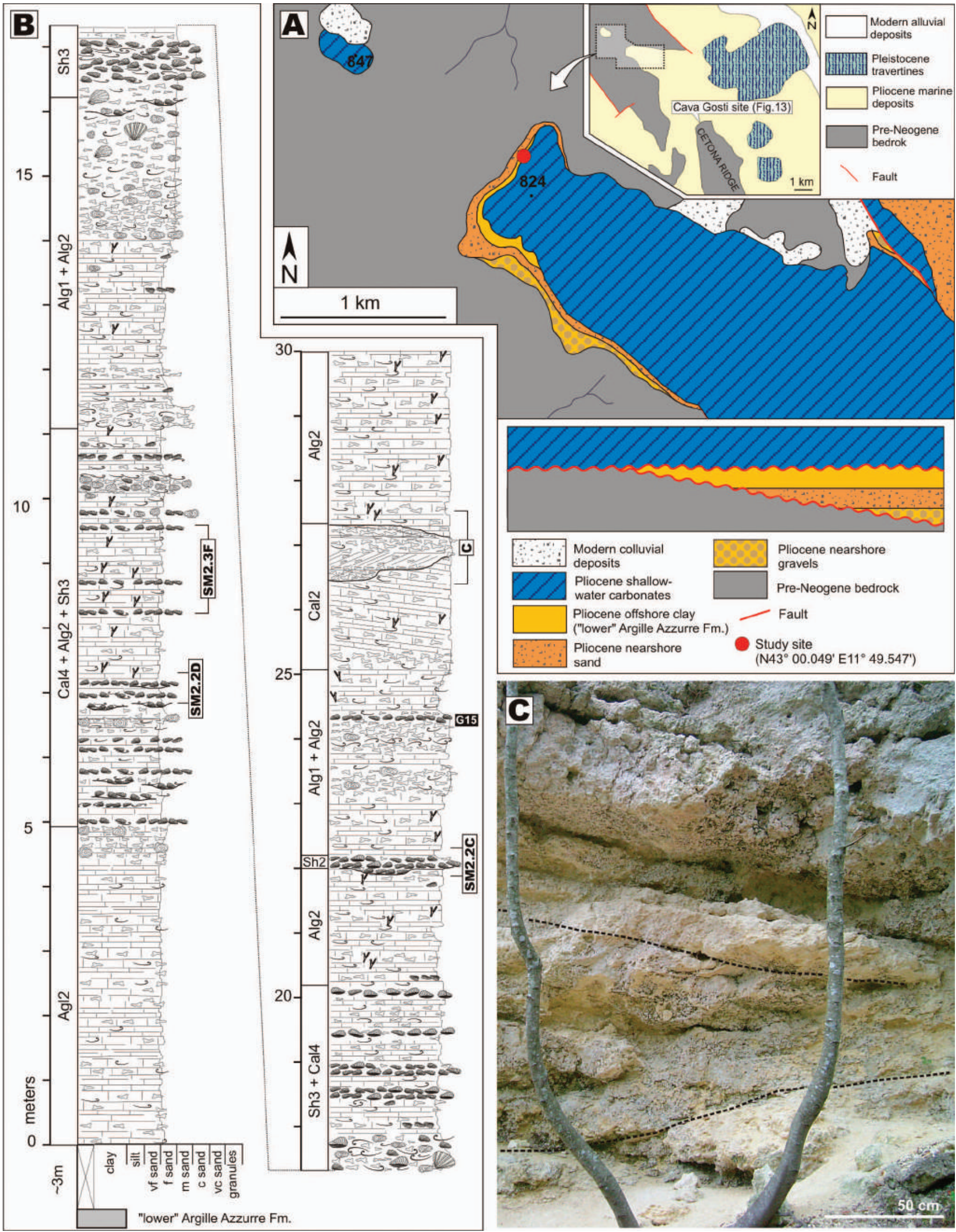


\section{Pianosa Island}

Pianosa is the only one of the seven islands of the Tuscan Archipelago in the Northern Tyrrhenian Sea that preserves a Neogene sedimentary cover. The island is a small emerged portion of a mostly submerged, N-Soriented structural high (Elba-Pianosa Ridge), bordered by NeogeneQuaternary basins (Pascucci et al. 1999; Cornamusini et al. 2002, 2014) (Fig. 1). The Pliocene carbonate unit is mostly visible along coastal cliff exposures (Foresi et al. 2008). A section was measured on a cliff exposure on the southern side of the island (Cala della Ruta, Fig. 15A, B).

Pianosa Unit: Description.-The base of the Cala della Ruta section preserves the contact with the underlying Miocene Golfo della Botte Fm. (here consisting of interbedded alluvial mud and conglomerates). The contact is represented by a mostly planar erosional unconformity, overlain by a basal conglomerate, $20 \mathrm{~cm}$ thick (facies $\mathrm{Cg} 1$ ), which grades upward into $\sim 2 \mathrm{~m}$ of massive sand with a subordinate carbonate component (Fig. $15 \mathrm{D})$. The sand contains some erosional scours filled with normally graded conglomerate. The overlying package $(\sim 3.5 \mathrm{~m}$ thick) contains several shellbeds (up to $80 \mathrm{~cm}$ thick) of Isognomon maxillatus (Lamarck, 1801) (facies Sh4), interspersed with irregular lenses and beds (up to $30 \mathrm{~cm}$ thick) of hybrid skeletal packstone to rudstone (facies Ha2). The remainder of the succession $(\sim 6 \mathrm{~m})$ consists of generally massive rudstone and packstone layers rich in red algae (facies Alg1 and Cal1), intercalated with some beds (up to $60 \mathrm{~cm}$ thick) richer in fine-grained matrix. Some of the beds rich in red algae have a denser framework at their base, with matrix-poor to openwork texture, and grade upward into a looser, matrix-rich framework.

The measured succession is capped by a hardened, $\sim 60$-cm-thick layer rich in red algae (facies Alg1) with a characteristic brownish color, showing diffuse oxidation and partial phosphatization of algal fragments and the matrix between granules. This horizon represents the top of the Pliocene unit and is unconformably overlain and laterally truncated by Pleistocene deposits (Foresi et al. 2008) (Fig. 15C) with at their base a gravelly lag containing clasts and fragments of the underlying phosphatized horizon. Magnetobiostratigraphic data (Table 3) constrain deposition of the studied Pianosa carbonate unit within Subchron C2An.3n (Fig. 2).

Pianosa Unit: Stratigraphic Interpretation.-The Pliocene deposits at Cala della Ruta show a clear upward decrease in siliciclastic content paralleled by an increase in finer-grained matrix. This trend is interpreted as recording a deepening-upward succession. The contact with the Miocene substrate represents a ravinement surface overlain by a transgressive basal conglomerate. Siliciclastic pebbles in the basal conglomerate and massive sand are reworked from erosion of the Golfo della Botte Fm., which contains numerous conglomerate layers. The interval dominated by Isognomon shellbeds documents the biological colonization of the substrate by this bivalve in relatively shallow waters (Betzler et al. 2000; Aguirre et al. 2008). The irregular lenses and beds of skeletal packstone interspersed with the shellbeds could be related to episodic high-energy events, which temporarily interrupted the growth and partially eroded the surface of the Isognomon banks (Fürsich et al. 2009). The transition to algal-dominated deposits in the upper part of the section probably reflects deepening linked to the progression of transgression. The capping layer, oxidized and with diffuse phosphatization, is interpreted as an incipient hardground, forming under conditions of sediment starvation during maximum flooding. The Pianosa carbonate unit would therefore record a complete TST bounded by a ravinement surface at its base and a maximum flooding surface at its top, successively reworked by the basal deposits of the following sequence.

\section{DISCUSSION}

\section{Timing and Tectono-Eustatic Control on Deposition of the Carbonate Units}

The magnetobiostratigraphic constraints presented in the results section (Fig. 2, Table 3) indicate that carbonate deposition recorded in the Pliocene of the Tuscan basins was restricted to the Piacenzian, occurring mostly within the lower to mid portion of the stage (planktonic foraminifera Subzones MPL4b and MPL5a; calcareous nannofossils Biozone MNN16; Subchrons C2An.3n, 2r, 2n, and possibly 1r and 1n). The chronostratigraphy for some localities (e.g., Roccastrada, Poggio del Gallo, Montefollonico; Fig. 2) is uncertain, with possible alternative chronostratigraphic placements that would result in a more extended interval of deposition of the carbonates. The preferred scheme proposed in Figure 2 minimizes the extent of this depositional interval, assuming a relatively concurrent response to the same regional signal. Even with this preference, however, a degree of diachroneity can be confidently established for deposition both within the same basin (e.g., among the Montegabbro and Pescille localities in the Valdelsa basin) and between units from different basins (e.g., Casciana Terme and Magliano units younger than Colombaio and Pianosa units) (Fig. 2).

A key finding of this study is the unconformable relationship of the studied units with the underlying deposits (Table 1, Fig. 2). This discontinuity, coupled with the chronostratigraphic data, indicates that the carbonates belong to the mid-Pliocene sequence identified on a broad scale by previous authors across several of the Tuscan and Tyrrhenian shelf basins (3rd UBSU of Boccaletti and Sani (1998); P2 of Bossio et al. (1998); Seq5 of Pascucci et al. (2007)). Widespread occurrence of an unconformity-bounded sequence such as the one to which the Piacenzian Tuscan carbonates belong implies a common underlying mechanism active at the regional scale. However, the diachronous onset of sedimentation in the Tuscan basins, with active deposition in some basins while others were still exposed (Fig. 2), implies that the regional trend was modulated by differential tectonic movements in the individual basins. Suggested mechanisms leading to the development of the basal unconformity and ensuing transgression include transition from syn-rift to post-rift tectonic regime, followed by general subsidence related to crustal thermal relaxation (Bartole 1995; Pascucci et al. 1999; Martini et al. 2001) or a compressional pulse related to activation of basement thrusts (Boccaletti and Sani 1998; Bonini et al. 2001; Bonini and Sani 2002). Emplacement of igneous intrusions from the early to mid-Pliocene (Dini et al. 2005; Brogi 2008), causing significant localized uplift (Marinelli et al. 1993; Acocella 2000), may also have played a role in the development of the basal unconformity and sedimentary style of the Piacenzian sequence for some of the Tuscan basins (Ghinassi 2005; Pascucci et al. 2006).

To assess if the unconformable onset of carbonate deposition records a eustatic component, data from the present study were compared to Pliocene high-resolution benthic $\delta^{18} \mathrm{O}$ records (Lisiecki and Raymo 2005) (Fig. 2). The curve shows a distinct positive spike in the lower Piacenzian (marine isotope stage (MIS) M2; Shackleton 1995) more pronounced than immediately preceding and following fluctuations (Fig. 2). MIS M2 is

FIG. 12.-The Cetona ridge carbonate unit. A) Geologic map of the Poggio del Gallo area. Bottom inset shows the vertical relationship of the lithostratigraphic units. Top

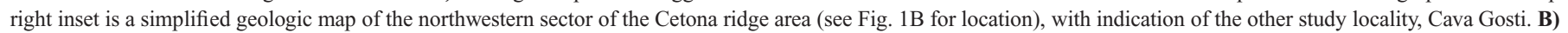

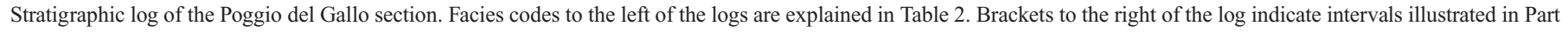

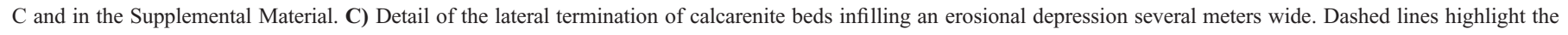
different dip direction of the beds respectively at the outside margin and within the depression. 

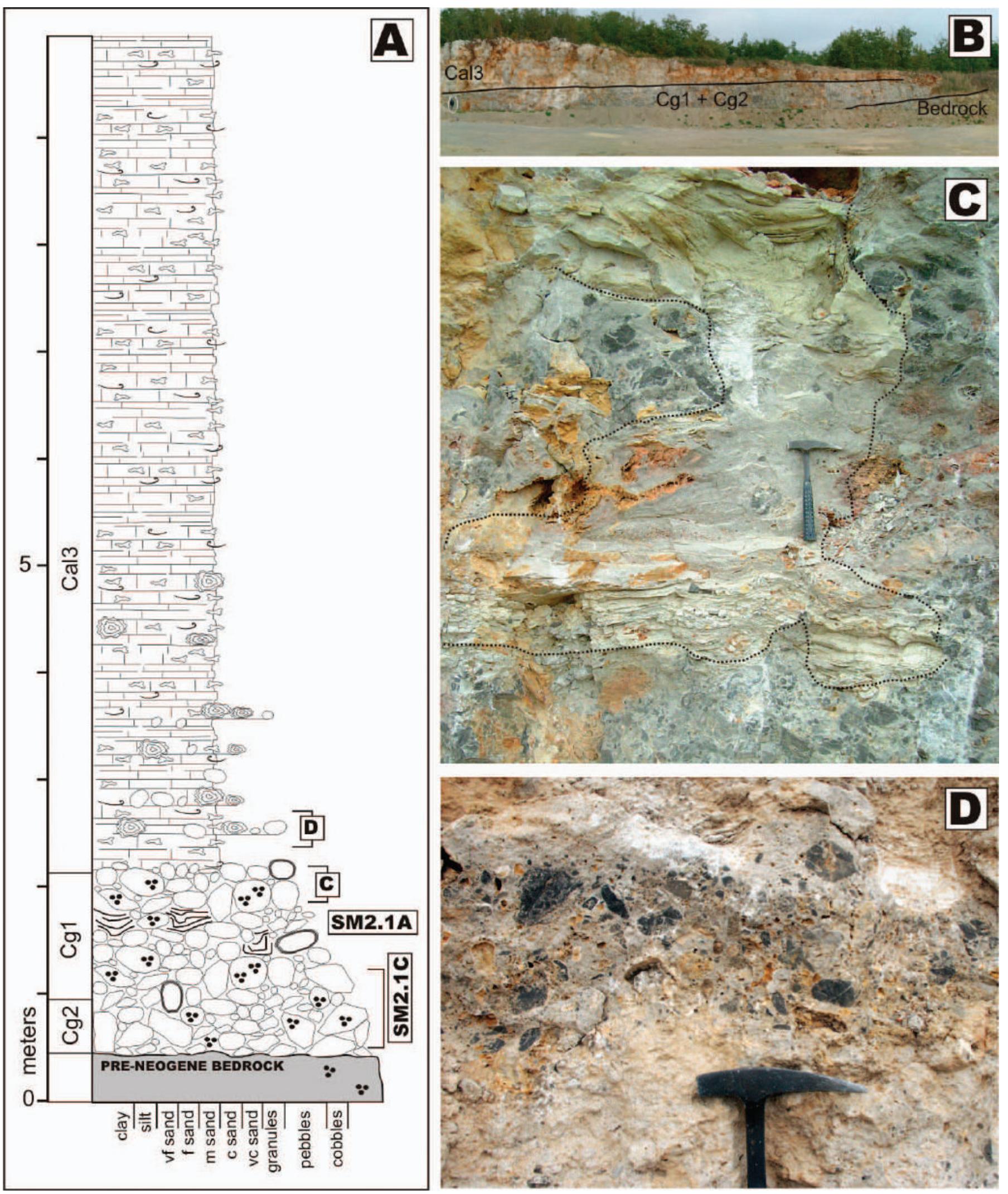

Fig. 13. - Cava Gosti section. A) Stratigraphic log of the Cava Gosti section (see Fig. 12A for location). Facies codes to the left of the logs are explained in Table 2. Brackets to the right of the log indicate intervals illustrated in Parts C and D, and in the Supplemental Material. B) View of the section, with contact with the pre-Neogene substrate exposed to the right. Ellipse encircles person for scale. C) Detail of an irregular pocket (margins highlighted by dashed line) within conglomerate deposits of facies $\mathrm{Cg}$ 1, filled with finer-grained sediment showing festoon stratification. Hammer for scale is $33 \mathrm{~cm}$ long. D) View of a coarser-grained layer within the calcarenites, containing lithic clasts coated with by a thin veneer of red algae laminae. Head of hammer for scale is $16 \mathrm{~cm}$ long. 

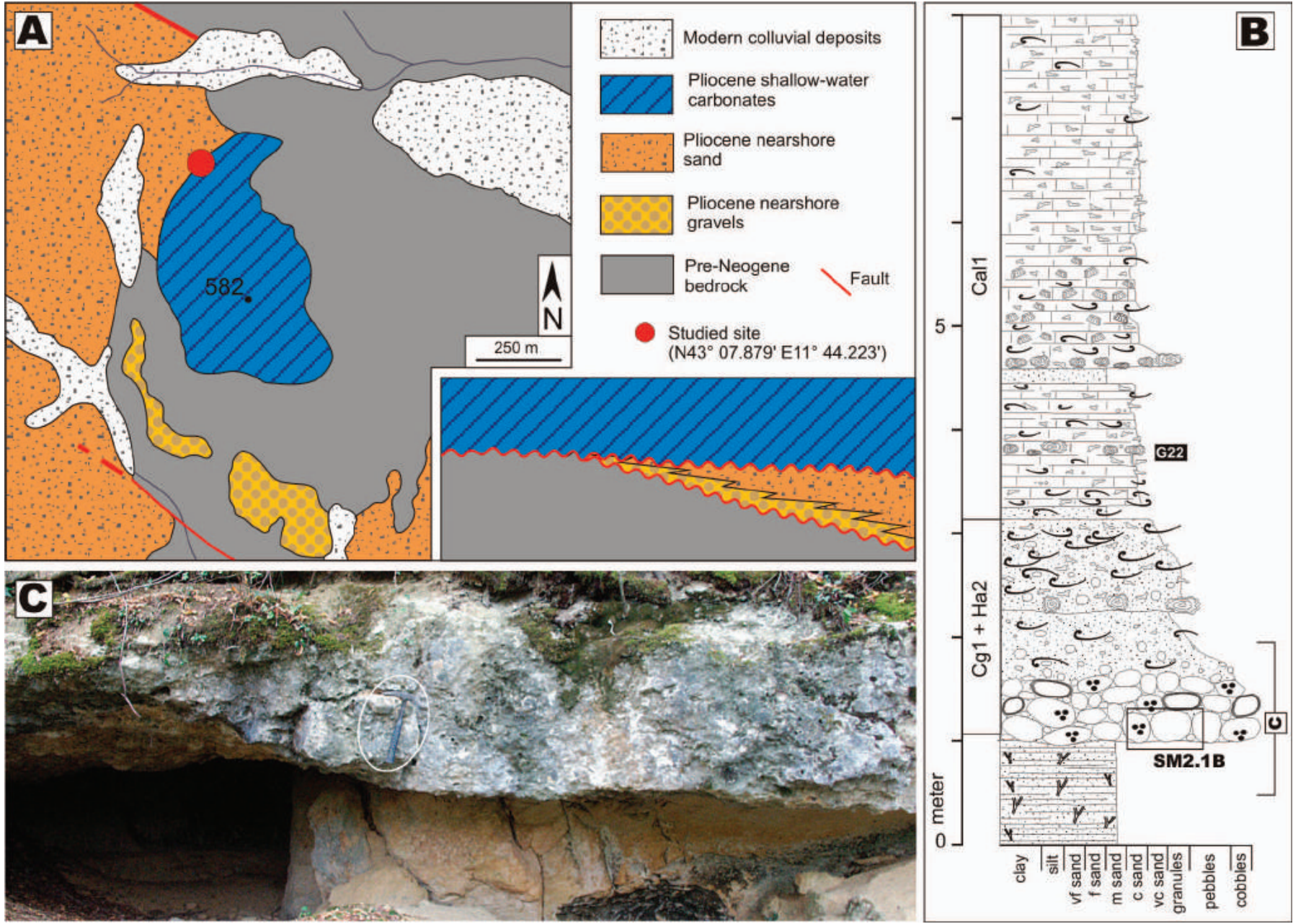

FIG. 14.-The Montefollonico carbonate unit. A) Geologic map of the Montefollonico area (see Fig. 1B for location). Bottom right inset shows the vertical relationship of the lithostratigraphic units. B) Stratigraphic log of the Montefollonico section. Facies codes to the left of the logs are explained in Table 2. Brackets to the right of the log indicate intervals illustrated in Part C and in the Supplemental Material. C) The basal unconformity of the carbonate unit. Hammer (encircled) for scale is 33 cm long.

commonly interpreted as related to a major cooling event accompanied by expansion of global ice volume and resulting sea-level drop of $\sim 80 \mathrm{~m}$, with a calibrated age of $\sim 3.3 \mathrm{Ma}$ (Miller et al. 2005; De Schepper et al. 2009; Dwyer and Chandler 2009). The chronostratigraphic data presented in this study show that the carbonate units either precede or follow the MIS M2 peak (Fig. 2). At some localities (e.g., Casciana Terme, Pescille, and possibly Magliano and Poggio del Gallo) the marine flooding documented by the carbonate units correlates well with the timing of deglaciation after the MIS M2 peak (Fig. 2). However, at other sites (e.g., Colombaio, Montegabbro, Pianosa) transgression predates this peak. It should be noted that none of the basins preserves a succession with two distinct successive carbonate depositional phases, respectively before and after the MIS M2 peak. However, it appears that the MIS M2 eustatic fluctuation amplified the effect of tectonics, with the drop in sea level marking a terminal uplift in some basins and the ensuing sea-level rise corresponding to the renewal of subsidence in others (Fig. 2)

\section{Nature of the Skeletal Association}

Piacenzian Tuscan carbonates from the different studied sites have a comparable skeletal association, consisting of red algae, bivalves, benthic foraminifera (including the larger benthic foraminifer Amphistegina), and echinoids as dominant components, along with bryozoans, barnacles, gastropods, serpulids, planktonic foraminifera, and brachiopods as subordinate components. Hermatypic corals, green calcareous algae, and nonskeletal grains are absent (Table 1). This association could be defined as rhodalgal-molechfor (Carannante et al. 1988) and transitional photozoan heterozoan (due to the presence of Amphistegina) (Halfar et al. 2004)

In modern oceans, a skeletal assemblage similar to that of the Piacenzian Tuscan carbonates is found both in tropical regions with predominantly mesotrophic conditions and in warm-temperate regions (Carannante et al 1988; Wilson and Vecsei 2005; Halfar et al. 2006). Lack of Halimeda, low diversity of larger benthic foraminifera, and scarcity and low diversity of corals is characteristic of today's warm-temperate regions (Wilson and Vecsei 2005). This is analogous to what we observed in the Piacenzian Tuscan carbonates, which lack green algae and corals, and contain only the larger benthic foraminifer Amphistegina. This foraminifer is among the most tolerant to lower temperatures, with modern distribution limited by the $14^{\circ} \mathrm{C}$ winter isotherms (Langer and Hottinger 2000). Attribution to a subtropical setting, with summer sea-surface temperature (SST) considerably warmer than $20^{\circ} \mathrm{C}$ and winter SST colder than $20^{\circ} \mathrm{C}$ (James 1997), is supported by paleoecological studies of Piacenzian molluscan faunas of the central Mediterranean, including data from the Tuscan basins (Monegatti and Raffi 2001).

The widespread occurrence of certain skeletal components across the different basins can also help in estimating the photic and trophic levels 

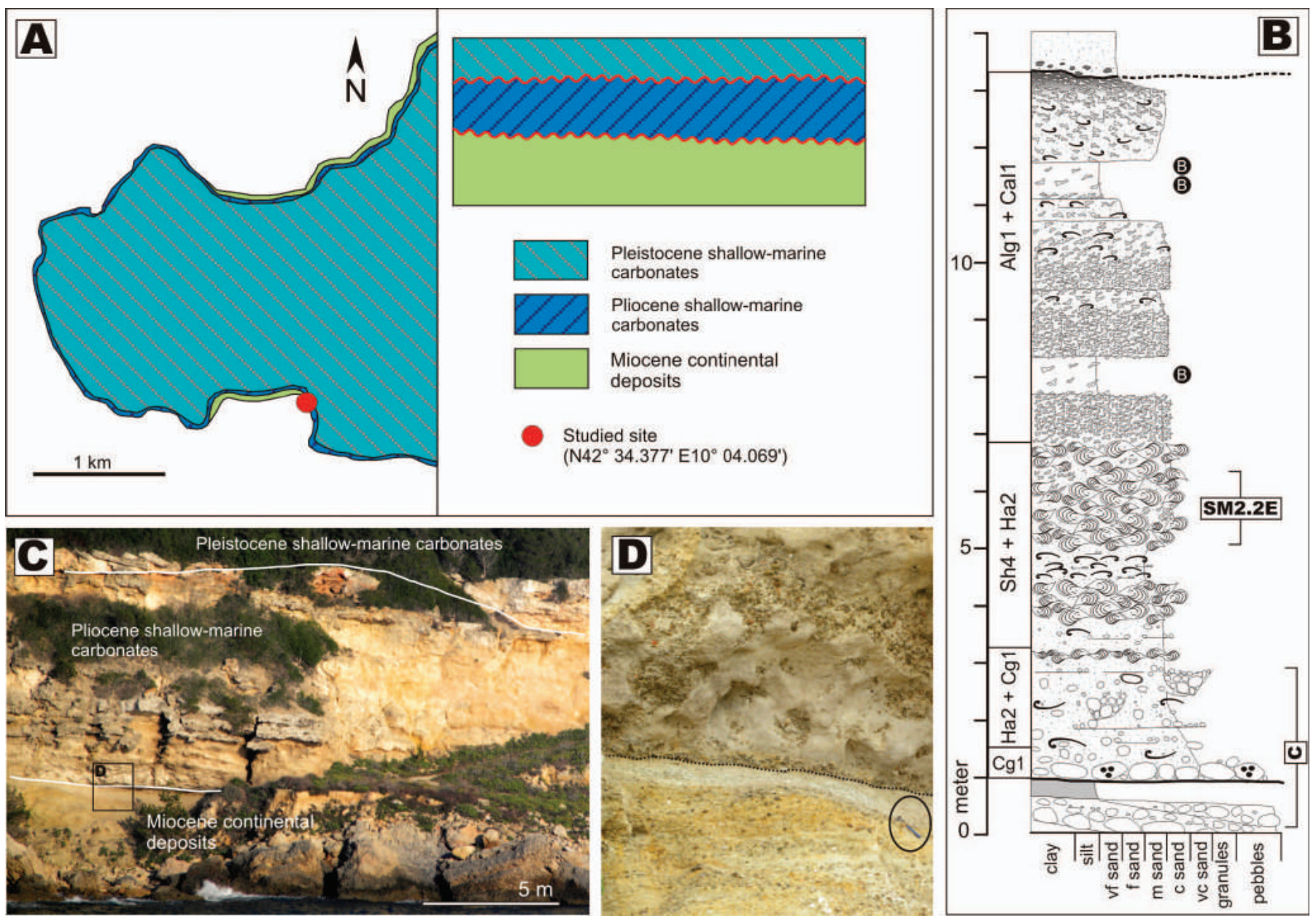

FIG. 15.-Pianosa, Cala della Ruta section. A) Geologic map of the southwestern portion of Pianosa Island (see Fig. 1B for location). Top right inset shows vertical relationship of the lithostratigraphic units. B) Stratigraphic log of the Cala della Ruta section. Facies codes to the left of the logs are explained in Table 2. Brackets to the right of the log indicate intervals illustrated in Part D and in the Supplemental Material. C) View of the outcrop, showing the unconformable bottom and top contacts of the Piacenzian carbonate unit. Area enlarged in Part D is indicated by a rectangle. D) Detail of the basal unconformable contact (dashed line) with the underlying Miocene deposits of the Golfo della Botte Fm. Hammer for scale (encircled) is $33 \mathrm{~cm}$ long.

that favored productivity of the Piacenzian carbonate factory. One of the most abundant components among the studied units are non-geniculate coralline red algae (Table 1), most commonly occurring as maërl facies (Alg1, Table 2). Through the study of modern deposits and PlioPleistocene successions, development of maërl beds in the Mediterranean region has been consistently shown to occur in a mid-ramp setting, in oligophotic waters (usually between 30 and $80 \mathrm{~m}$ ), below the level of seagrass meadows (Canals and Ballesteros 1997; Pedley and Grasso 2002; Martín et al. 2004; Brandano and Civitelli 2007; Nalin and Massari 2009; Sciberras et al. 2009). Another significant component of the Piacenzian Tuscan carbonates is the larger benthic foraminifer Amphistegina. Living populations of Amphistegina are currently found in the central and eastern regions of the Mediterranean Sea, generally on hard or phytal substrates at shallow to intermediate depths of the photic zone $(0-60 \mathrm{~m})$ (Hollaus and Hottinger 1997; Hyams et al. 2002; Yokes et al. 2007; Triantaphyllou et al. 2009). Similarly to other larger benthic foraminifera, Amphistegina thrives in oligotrophic conditions because of the ecological advantage of efficient nutrient recycling conferred by harboring photosynthetic algal endosymbionts (Hallock 1981; Hallock 2000). The scarcity of bryozoans, which, being heterotroph, usually become a predominant component of neritic associations in deeper or eutrophic environments (Corda and Brandano 2003; Halfar et al. 2006), combined with the abundance of Amphistegina and coralline algae, which generally experience significant stress under highly eutrophic conditions (Wilson et al. 2004), suggest that carbonate deposition in the Tuscan basins during the early to mid-Piacenzian took place in overall mesotrophic to oligotrophic and euphotic to oligophotic conditions.

\section{Stratigraphic Expression of the Carbonate Depositional Interval}

The physical expression of a pulse of deposition in the context of a sedimentary cycle is a complex function of the local interplay of sediment budget (including type of carbonate productivity) and available accommodation (Catuneanu 2002; Pomar and Kendall 2008), and should therefore be expected to display high variability among distinct basins. Nevertheless, the results of a stratigraphic analysis of the Tuscan carbonates shows that the studied units can still be organized in two main categories (Fig. 16).

The first group is represented by carbonate units that are restricted to the transgressive portion of the sequence to which they belong, directly overlying the basal unconformity and often overlain by offshore clays. These transgressive carbonate units can be relatively expanded and display internal higher frequency cyclicity (e.g., Pomarance area) or consist of a relatively thin veneer of carbonate deposits (e.g., Montegabbro area), 
TRANSGRESSIVE

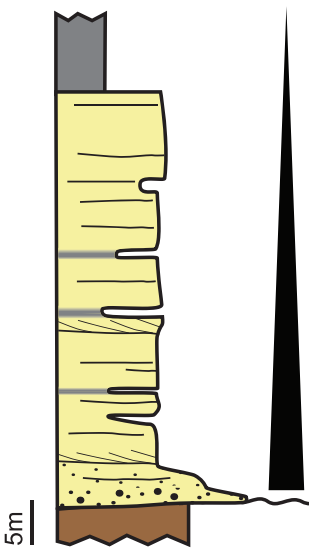

Pavone Creek (Pomarance unit) (Fig. 6A)

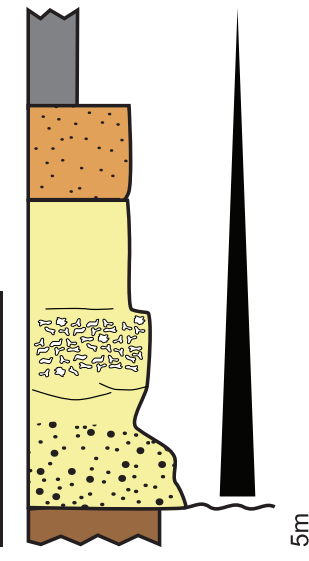

Montegabbro (Fig. 10)

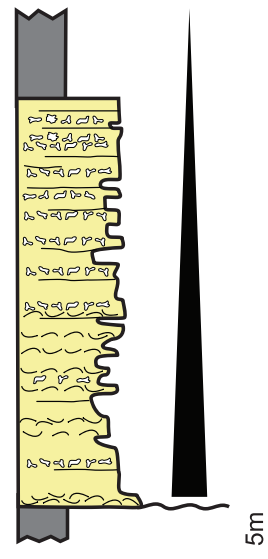

Colombaio (Fig. 11)

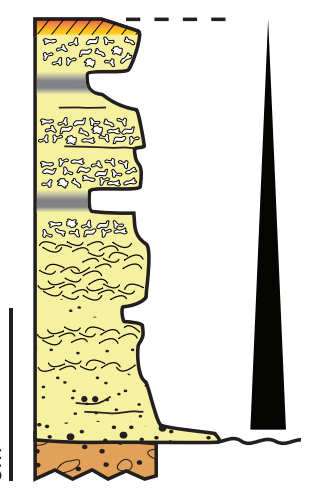

Pianosa (Fig. 15)
LEGEND

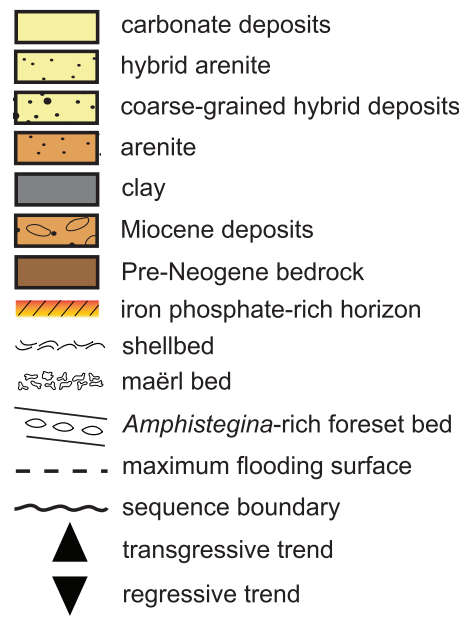

TRANSGRESSIVE-REGRESSIVE

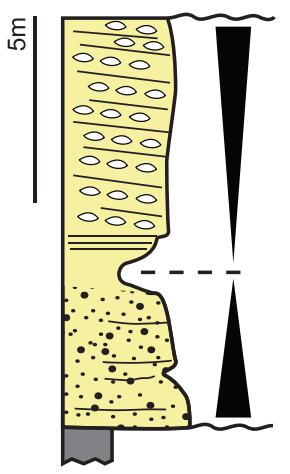

Casciana Terme, lower cycle (Fig. 4)

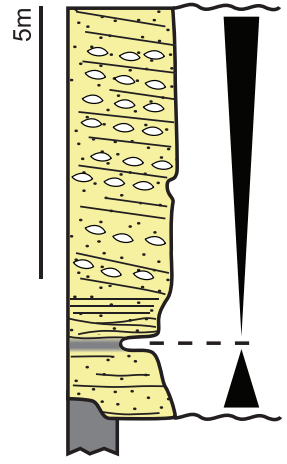

Patrignone Creek (Magliano unit) (Fig. 9A)

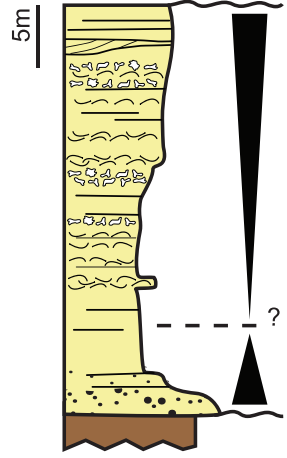

Cava Gosti + Poggio del Gallo (Cetona unit) (Figs. 12,13)

\section{UPDIP TRANSGRESSIVE-REGRESSIVE}
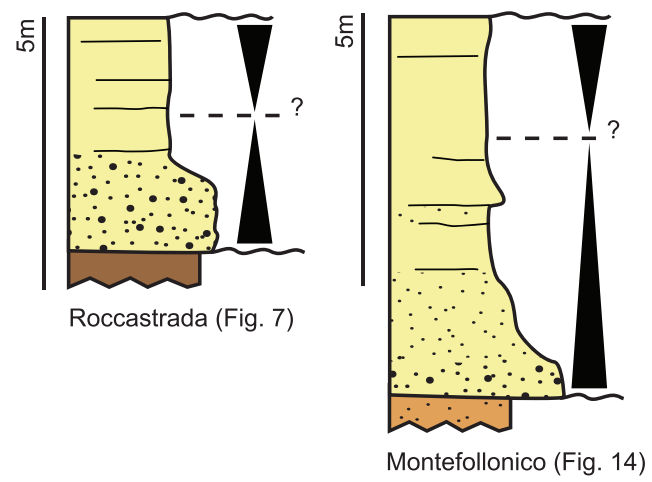

FIG. 16.-Grouping of the studied Piacenzian units from the Tuscan basins based on the position occupied by carbonate deposits within a stratigraphic cycle. Transgressive

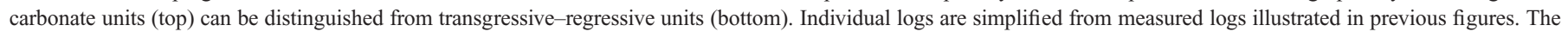
Poggio del Gallo and Cava Gosti sections from the Cetona unit have been unified in a composite section. For geographic location of individual sections see Figure 1.

reflecting the varied interplay of productivity of the carbonate factory, rate of relative sea-level change, and inherited physiography (Kamp and Naish 1998; Cattaneo and Steel 2003). The transgressive stratigraphic pattern is interpreted primarily as an expression of depth-related controls limiting the formation of shallow-marine carbonates. Initial base-level rise during early transgression may favor the onset of carbonate deposition, by providing new substrate within the photic zone for calcifying benthic communities and through landward confinement of siliciclastic input (Carey et al. 1995; Meldahl et al. 1997). Sustained deepening, however, eventually causes drowning or landward relocation of the shallow carbonate factory and a switch to a more pelagic style of sedimentation (Gillespie et al. 1998; Vecsei and Sanders 1999), documented in the Tuscan basins by the upward transition to the offshore clays of the upper Argille Azzurre Fm. (Fig. 16). Demise of carbonate sedimentation in the Tuscan basins could also have entailed a climate-oceanographic component, resulting in increase of terrigenous supply from terrestrial runoff and local changes in water circulation and trophic levels, the latter possibly documented by deposition of the iron- and phosphate-rich condensed horizon capping the Pianosa unit (Mutti and Bernoulli 2003). Drowning of carbonate platforms has often been linked to changes in environmental parameters (Godet 2013) and climate-driven changes in precipitation have been invoked to account for an analogous and coeval transition from shallow marine carbonates to clays in Piacenzian deposits of the Northeastern Apennines (Capozzi and Picotti 2003).

The second group consists of carbonate units that span across most or all of the preserved sequence, including its regressive portion (Fig. 16). This stratigraphic pattern reflects a balance between base-level change and carbonate productivity, sufficient to prevent drowning and maintain active carbonate aggradation through most of the depositional cycle. A variant on this motif, documented also in other carbonate successions (Rankey et al. 1999; Caron et al. 2004), is represented by carbonate units in relatively updip locations (Fig. 16) that experienced marine conditions only for a limited time between initial flooding and subsequent subaerial exposure of the depositional site. In these cases, the carbonate unit of limited thickness overlying the basal transgressive deposits could include an upper portion formed during early regression before the ensuing emersion. An alternative hypothesis would be that formation of the upper sequence boundary entailed significant erosion of deeper facies originally overlying the carbonate package. In this case, the units should be considered as fully transgressive. However, regional studies attest to the lack of remnants of deeper marine deposits in the larger areas surrounding the Roccastrada and Montefollonico sites (Bossio et al. 1993) and suggest that these carbonate units represent the maximum extent of marine flooding at basin-margin locations before generalized uplift. 


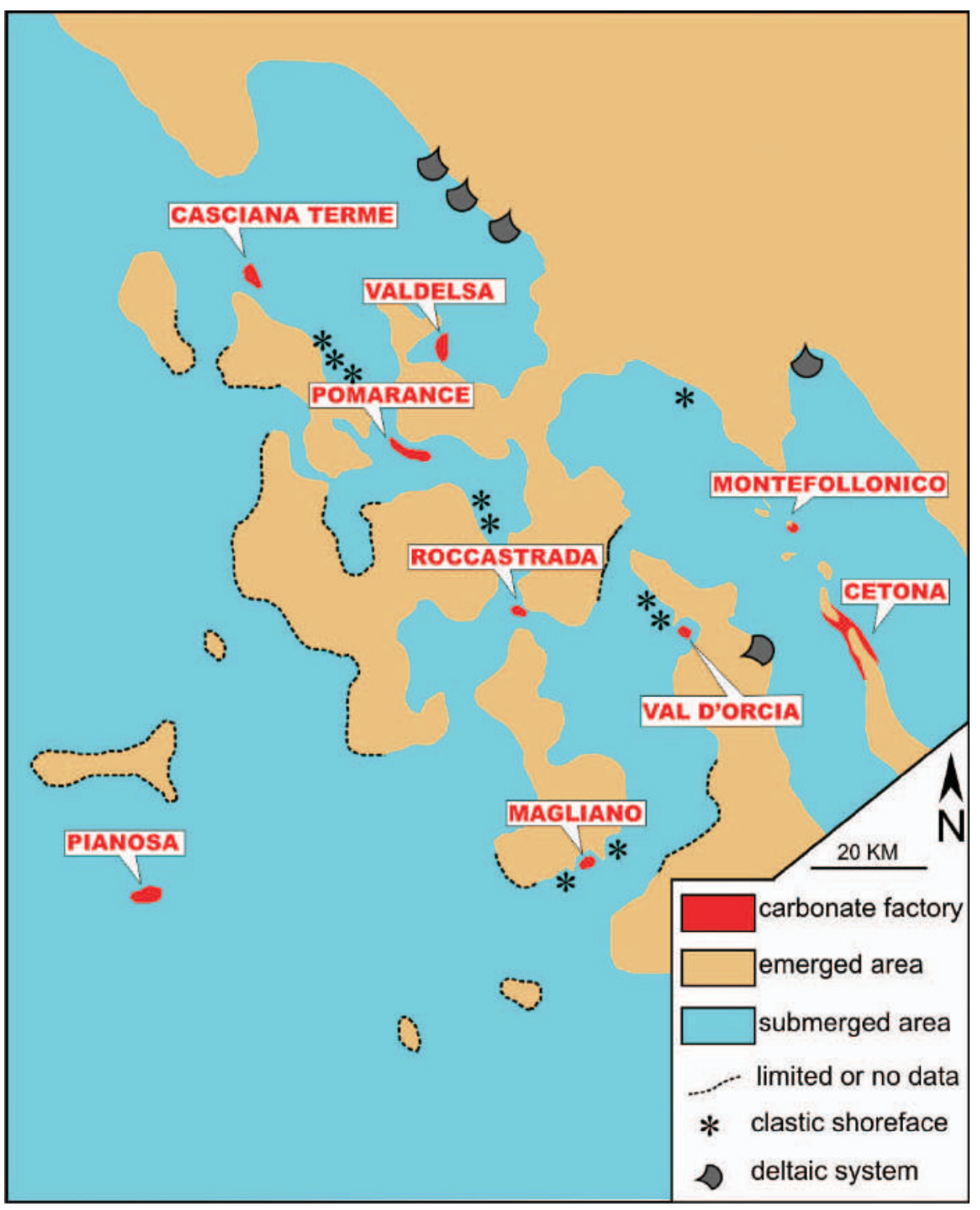

FIG. 17.-Paleogeographic reconstruction of the Tuscan coastal domain in the early to midPiacenzian, based on the preserved distribution of Piacenzian marine deposits (Fig. 1B) and data from Bartole (1995) and Bossio et al. (1995). Areas of carbonate productivity discussed in this study and coeval siliciclastic shorelines and deltaic systems based on a literature compilation are also indicated.

\section{Carbonate Deposition in Restricted Basins}

A paleogeographic reconstruction (Fig. 17) based on onlap relationships and extent of the deposits of the Piacenzian sequence (Fig. 1B) (Bartole 1995; Bossio et al. 1995) illustrates the complex physiography of the Tuscan coastal domain during the early to mid-Piacenzian transgression. Precise positioning of the shoreline along the westernmost margin, in the Tyrrhenian shelf area, is hampered by the lack of preservation of Pliocene deposits, but the generic presence of emerged landmasses has been established by provenance studies of magmatic clasts (Pandeli et al. 2010). Conversely, Piacenzian coastline reconstructions in the Tuscan basins can be more confidently established in spite of subsequent uplift and localized erosion of the Pliocene deposits. Plotted on the map are not only the carbonate units but also areas with coeval clastic shorelines and deltaic systems documented in the literature (Bossio et al. 1991b, 1991c; Bossio et al. 1993; Bossio et al. 2003-2004; Aruta et al. 2004; Nalin et al. 2010; Martini et al. 2011; Benvenuti et al. 2014; Marroni et al. 2015).

The archipelago-like configuration of the tectonically structured Piacenzian Tuscan shelf (Fig. 17) allows discussion of general principles affecting carbonate deposition in areas of complex coastal physiography during a regional transgression. The mostly heterozoan skeletal association of the Tuscan carbonates shares more similarities with other deposits from the Mediterranean region, such as the Neogene basins of the Betic Cordillera in Spain (Gläser and Betzler 2002; Braga et al. 2006 and references therein; Braga et al. 2010; Puga-Bernabéu et al. 2010), than with photozoan-dominated carbonate systems. However, the following discussion also considers examples from tropical reef systems and focuses on the impact of physiography rather than climate, although physical parameters influencing carbonate deposition are clearly interconnected (Lukasik and Simo 2008; Pomar and Kendall 2008).

Available Shelf Area and Antecedent Topography.-The first level of control on the size and location of carbonate deposition in settings with varied coastal physiography is exerted by spatial fragmentation resulting from the presence of numerous emerged landmasses, which interrupt the continuity of a shallow shelf. The result is a patchier distribution and more limited size of carbonate accumulations (Table 1, Fig. 17) when compared with other Mediterranean ramp systems developed on relatively continuous open shelves (e.g., Guillem et al. 2008). A physiography characterized by structural highs separated by intervening depressions also restricts potential 
sites of shallow-water carbonate production to the shelf area around or above emerged and submerged highs respectively. The actual extent of these carbonate factories is a function of the width and flank steepness of the structural highs (Dorobek 2008), but the general result is a plan-view distribution that follows the margins of emerged landmasses or the main linear trends of elongated highs (Bosence 2005). This is particularly evident among the Piacenzian Tuscan carbonates in the Cetona unit, which follows the nearly linear margins of the Cetona ridge (Fig. 17), but the Pomarance, Casciana Terme, and Magliano units also onlap (Fig. 5) and extend along basin-margin flanks (Fig. 17). On the other hand, the Pianosa and Montefollonico units most likely developed over isolated highs (Figs. 14, 17). This pattern of distribution of platform inception along structural highs has been particularly well documented in rift-basin carbonate systems, both in tropical-type platforms (e.g., Miocene of the Gulf of Suez; Cross and Bosence 2008) and in the Mediterranean region (e.g., Miocene Sardinia Rift Basin; Vigorito et al. 2010). However, the link between submerged topographic highs and areas of carbonate accumulation has also been established in different tectonic settings, such as wedge-top basins (e.g., Miocene of the NE Apennines; Fontana et al. 2015) and even foreland basins experiencing compartmentalization due to active growth of anticlinal folds (Saura et al. 2013).

Role of Clastic Input.- - Most of the Piacenzian Tuscan carbonate units contain intervals of mixed siliciclastic-carbonate composition (Fig. 16) and developed in proximity of coeval siliciclastic shorelines and deltaic systems (Fig. 17). The effect of terrigenous influx on carbonate deposition in these restricted basins can be better constrained when compared with other similar described examples. A consistent pattern observed in settings with several parallel basins separated by intervening ridges is the preferential development of carbonates away from the innermost margin adjacent to the exposed hinterland (Cross and Bosence 2008; Dorobek 2008). This distribution reflects the localization and confinement of clastic inputs from the main emergent landmass in the most proximal basins, and, in rift settings, the generally steep flank of the rift edge (Dorobek 2008). A similar situation, with trapping of clastic input in proximal basins influencing the locus of carbonate accumulations, is described for the Miocene of Crete by Reuter et al. (2006). This model applies well to what is observed in the Tuscan basins, most of which were not directly adjacent to the main Apenninic landmass but located farther offshore and separated by several intervening ridges (Figs. 1, 17). The highest volume of sediment discharge, connected to more developed drainage systems, was trapped in the peripheral basins of the Apenninic chain (Fidolini et al. 2013) or affected the eastern margins of the Valdelsa, Siena, and possibly Val di Chiana basins (Figs. 1, 17), where deltaic deposits are well documented (Aruta et al. 2004; Martini et al. 2011; Benvenuti et al. 2014) and carbonate deposits are absent. This would also help explain why the Pianosa transgressive unit, which was located farthest away from the continental margin and terrestrial influx, does not record deposition of the upper Argille Azzurre but was affected by complete starvation, as attested by the phosphatic condensed horizon (Figs. 15, 16).

Separation from hinterland drainage systems in more distal basins also implies that siliciclastic material must be locally derived from wave erosion of the substrate, cliff retreat, or small drainage networks on adjacent emerged highs (Gómez-Pujol et al. 2013). This appears to be the case for most of the siliciclastic component in the Tuscan carbonate units, as especially shown by the coarse-grained facies ( $\mathrm{Cg} 1, \mathrm{Cg} 2$; Tab. 2) at Pavone Creek (Fig. 6), Cava Gosti (Fig. 13), and Pianosa (Fig. 15) that contain lithic fragments eroded from the local substrate. When sources of clastic input are primarily local, differences in substrate type become an important factor that can influence carbonate sedimentation. In areas of complex coastal morphology, sediment exchange between separated nearshore domains may be limited, giving rise to distinct petrographic differences in clastic composition reflecting local substrate variability (Gómez-Pujol et al.
2013). These differences may in turn affect levels of water turbidity and nutrients, creating sharp transitions from siliciclastic-dominated to carbonate-dominated areas. In the Tuscan basins, the lithology of the substrate varied considerably among and within basins and intervening landmasses, ranging from unconsolidated Mio-Pliocene deposits to Triassic to Paleogene bedrock (Table 1). Nalin et al. (2010) reported how this variability was a significant factor affecting the development of a carbonate factory in the Val D'Orcia basin. Patterns of transport of siliciclastic influx along a complex coastline can also determine lateral differences impacting the onset of carbonate accumulations. McNeill et al. (2004) pointed out how these transitions can be relatively abrupt, based on examples from the Neogene of South Florida. The combined effect of substrate lithology, complex physiography, and sediment transport patterns can result in the lateral coexistence of carbonate-dominated and siliciclastic-dominated shorelines, as observed in the Volterra, Radicondoli-Chiusdino, Albegna, and Val d'Orcia basins (Fig. 17).

Clastic input can also influence the type of carbonate-producing biota and consequently the type of carbonate accumulation. Gläser and Betzler (2002), for example, described an example from the Miocene of southern Spain where variations in skeletal association were linked to differences in siliciclastic influx. Among carbonate producers, red algae, larger benthic foraminifera, and ostreid bivalves appear to have higher tolerance for sustained rates of terrigenous influx (Lokier et al. 2009; Vigorito et al. 2010; Brandano and Ronca 2014; Novak and Renema 2015). This corresponds well with the composition of mixed intervals in the Piacenzian Tuscan units, where red algae (e.g., Cala della Ruta section, Pianosa unit), Amphistegina (e.g., Patrignone Creek section, Magliano unit), and subordinately ostreids (e.g., Pavone Creek section, Pomarance unit) are the main skeletal component in hybrid facies. The type of clastic input can also affect the nature of the carbonate association. Studies of modern communities dominated by red algae, for example, have shown that mixing with coarse clastic sediment (as observed in the Magliano carbonate unit) can be tolerated more easily than smothering with fine sediment (Wilson et al. 2004; Halfar et al. 2006; Peña and Bárbara 2008).

Another aspect to consider is the relationship between clastic input and carbonate deposition in a dynamic context of regional transgression. In the Tuscan basins (Fig. 16) and in other restricted basins (Martín et al. 1996; Dorobek 2008; Nalin et al. 2008; Fontana et al. 2015) mixed siliciclasticcarbonate facies most commonly occur in the basal conglomerate or lowermost portion of carbonate units. This stratigraphic position suggests that clastic detritus was mainly locally derived from substrate erosion during transgression. Upward decrease in siliciclastics reflects reduction of the area of emerged landmass, size of drainage systems, and amount of terrigenous debris produced as transgression progressed. In the Tuscan basins, however, there is at least one example (Magliano unit, Fig. 9) where mixing with terrigenous material is recorded throughout the section, including its regressive portion, pointing to relative proximity to sustained terrigenous influx as documented by adjacent clastic shorelines (Bossio et al. 2003-2004) (Fig. 17).

Hydrodynamic Setting.- Restricted basins are generally characterized by lower energy hydrodynamic regimes compared to their open-ocean counterparts (Braga et al. 2006), resulting in significantly shallower depths of fair weather-wave base (Pedley and Grasso 2002). In addition, a complex coastal physiography is known to locally shelter even high-energy carbonate depositional settings from the effects of vigorous circulation (Ryan et al. 2008). Low- to moderate-energy conditions in the Tuscan Piacenzian carbonate units are reflected in the relatively rare physical sedimentary structures indicative of wave and current activity, even at the most proximal locations (e.g., Cava Gosti, Fig. 13), and the abundant and ubiquitous occurrence of bioturbation. However, sediment mobilization during episodic storm events seems to have been a significant process punctuating quiet background sedimentation. For example, shellbeds such 
as those observed at the Colombaio and Poggio del Gallo sections (facies Sh3, Table 2) have been interpreted as related to transport during storm events (Nalin et al. 2010). Similarly, construction of basinward-prograding clinoform bodies located in areas facing more open-water conditions (Casciana Terme and Magliano, Fig. 17) and characterized by abundance of abraded skeletal fragments, preferred orientation of elongated bioclasts, general lack of fine-grained matrix, and distinct bedding with normal grading and plane-parallel lamination (see facies Alg3 and Amph1, Table 2) suggests episodic activation of offshore transport during high-energy events.

\section{CONCLUSIONS}

This study has investigated the timing, composition, and stratigraphic expression of carbonate deposition in otherwise siliciclastic-dominated Pliocene successions of the Tuscan basins, with the aim of characterizing patterns of shallow marine carbonate sedimentology in tectonically structured shelves with complex physiography.

Spatially discontinuous carbonate units, of variable areal extent and constituted by calcareous red algae, the larger benthic foraminifer Amphistegina, and skeletal components of the heterozoan association, were deposited slightly diachronously in different Tuscan basins during the Piacenzian, in an interval constrained by new magnetostratigraphic and biostratigraphic analysis to planktonic foraminifera Subzones MPL4b and MPL5a, calcareous nannofossils Biozone MNN16, and Subchrons C2An.3n, 2r, 2n, and possibly $1 \mathrm{r}$ and $1 \mathrm{n}$.

At all studied sites, the vertical transition from bedrock or siliciclastic deposits to the overlying carbonate unit is marked by a stratigraphic discontinuity, with the carbonates being part of an unconformity-bounded sequence that can be recognized at a regional scale. Sequence development was controlled by a combination of background tectonic evolution of the Tuscan basins with superimposed eustatic effects, in particular those linked to a significant sea-level drop and ensuing transgression indicated by the MIS M2 excursion of oxygen isotope curves.

Common features emerge when comparing patterns observed in the Tuscan carbonate units with other examples of shallow-marine carbonate deposition in restricted basins described in the literature. In particular:

1) Carbonate accumulation associated with transgression is documented in all studied units by the formation of an unconformably-based transgressive package. This basal interval either a) transitions upward to clay-dominated deposits or to a condensed interval (indicative of drowning of the carbonate factory or changes in trophic levels); or b) is overlain by a regressive succession of carbonate-dominated deposits, reflecting keep-up conditions between carbonate productivity and base-level change. As a result, two distinctive stratigraphic motifs (transgressive and transgressiveregressive) characterize these successions.

2) Spatial fragmentation of a shelf results in smaller and discontinuous carbonate accumulations located along the margins of emergent structural highs or above submerged highs. Where the physiography of the shelf consists of parallel depressions separated by intervening ridges, carbonate units preferentially develop in basins located further from the hinterland margin, because of trapping of siliciclastic influx in more proximal basins.

3) Mixed carbonate-siliciclastic facies in carbonate units of restricted basins commonly occur in the basal transgressive portion of the units, reflecting local sources of production of clastic detritus from substrate erosion during transgression. Differences in substrate lithology, sediment dispersal patterns interacting with a complex coastline, and variable tolerance of carbonate producers to detrital input often result in the coexistence within the same basin of carbonate-dominated and siliciclasticdominated shorelines with sharp lateral transitions.

4) A varied physiographic setting differs from linear open shelves in generating carbonate accumulations with facies characteristics of low- to moderate-energy hydrodynamic conditions, reflected by relatively rare physical sedimentary structures and abundance of bioturbation. However, creation of sheltered carbonate production areas in an archipelago-like coastal domain does not preclude a significant signature of high-energy episodes, such as events generating shell concentrations or redeposition over clinoform slopes, from being locally preserved in the successions.

5) In spite of local variability in dominant skeletal components between distinct restricted basins, a general ecological signature for a regional pulse of carbonate deposition can still be extracted when considering the skeletal association as a whole. In the case of the Tuscan basins, Piacenzian carbonates appear to have been deposited under overall mesotrophic to oligotrophic conditions, mostly at euphotic and oligophotic depths, in a warm-temperate setting.

\section{SUPPLEMENTAL MATERIAL}

Two files are available from JSR's Data Archive: http://sepm.org/pages.aspx? pageid $=229$.

\section{ACKNOWLEDGMENTS}

We are indebted to E. Fornaciari (University of Padova) for providing biostratigraphic analysis on the calcareous nannoplankton associations. Editor L. Melim, Associate Editor E. Samankassou, and an anonymous reviewer helped improve the manuscript through valuable comments. This research was partly funded through a postdoctoral research grant of the University of Padova to R.N. and M.G., and a Progetto di Ateneo grant of the University of Padova (2008, prot. CPDA083815) to M.G. We thank the Tuscan Archipelago National Park for granting permission to work in the Island of Pianosa.

\section{REFERENCES}

Acocella, V., 2000, Space accommodation by roof lifting during pluton emplacement at Amiata (Italy): Terra Nova, v. 12, p. 149-155.

Aguirre, J., Martín, J.M., Braga, J.C., Betzler, C., Berning, B., and Buckeridge, J.S., 2008, Densely packed concentrations of sessile barnacles (Cirripedia: Sessilia) from the Early Pliocene of SE Spain: Facies, v. 54, p. 193-206.

Aruta, G., Borgia, A., Bruni, P., Cecchi, G., Cipriani, N., and Tredici, Y., 2004, Pliocene and Pleistocene unconformity bounded stratigraphic units (UBSU) in Val di Chiana, in Morini, D., and Bruni, P., eds., The "Regione Toscana" Project of Geological Mapping: Firenze, Martinelli, p. 133-136.

Bartole, R., 1995, The North Tyrrhenian-Northern Apennines post-collisional system: constraints for a geodynamic model: Terra Nova, v. 7, p. 7-30.

Benvenuti, M., Del Conte, S., Scarselli, N., and Dominici, S., 2014, Hinterland basin development and infilling through tectonic and eustatic processes: latest MessinianGelasian Valdelsa Basin, Northern Apennines, Italy: Basin Research, v. 26, p. 387-402. Bernini, M., Boccaletti, M., Moratti, G., Papani, G., Sani, F., and Torelli, L., 1990, Episodi compressivi neogenico-quaternari nell'area estensionale tirrenica nord-orientale: dati in mare e a terra: Società Geologica Italiana, Memorie, v. 45, p. 577-589.

Betzler, C., Martín, J.M., and Braga, J.C., 2000, Nontropical carbonates related to rocky submarine cliffs (Miocene, Almería, southern Spain): Sedimentary Geology, v. 131, p. 51-65.

Boccaletti, M., AND SANI, F., 1998, Cover thrust reactivations related to internal basement involvement during Neogene-Quaternary evolution of the northern Apennines: Tectonics, v. 17, p. 112-130.

Boccaletti, M., Elter, P., And Guazzone, G., 1971, Plate tectonic models for the development of the Western Alps and Northern Apennines: Nature-Physical Science, v. 234, p. $108-111$.

Bonini, M., AND SANI, F., 2002, Extension and compression in the Northern Apennines (Italy) hinterland: evidence from the late Miocene-Pliocene Siena-Radicofani Basin and relations with basement structures: Tectonics, v. 21, p. 1-32.

Bonini, M., Boccaletti, M., Moratti, G., and Sani, F., 2001, Neogene crustal shortening and basin evolution in Tuscany (Northern Apennines): Ofioliti, v. 26, p. 275-286.

Bosence, D., 2005, A genetic classification of carbonate platforms based on their basinal and tectonic settings in the Cenozoic: Sedimentary Geology, v. 175, p. 49-72.

Bossio, A., Mazzanti, R., Mazzei, R., Menesini, E., Nencini, C., Salvatorini, G., And UGhi, R., 1981, Nuove osservazioni sulla stratigrafia delle formazioni plioceniche e pleistoceniche di Casciana Terme: Società Paleontologica Italiana, IX Convegno, p. 91-120.

Bossio, A., Costantini, A., Foresi, L.M., Mazzei, R., Monterforti, B., Salvatorini, G., And Sandrelli, F., 1991a, Notizie preliminari sul Pliocene del bacino del medio Ombrone e della zona di Roccastrada: Società Toscana di Scienze Naturali, Atti, Memorie Serie A, v. 98, p. 259-269. 
Bossio, A., Mazzanti, R., Mazzei, R., Salvatorini, G., and Sandrelli, F., 1991b, Il Pliocene dell'area di Pomarance (Pisa): Società Toscana di Scienze Naturali, Atti, Memorie Serie A, v. 98, p. 1-98.

Bossio, A., Mazzanti, R., Mazzei, R., Salvatorini, G., and Sandrelli, F., 1991c, Il Pliocene di S. Dalmazio-Anqua e Radicondoli-Belforte (Siena e Pisa): SocietaToscana di Scienze Naturali, Atti, Memorie Serie A, v. 98, p. 99-191.

Bossio, A., Costantini, A., Lazzarotto, A., Liotta, D., Mazzanti, R., Mazzei, R., Salvatorini, G., AND SANDrelli, F., 1993, Rassegna delle conoscenze sulla stratigrafia del Neoautoctono toscano: Società Geologica Italiana, Memorie, v. 49, p. 17-98.

Bossio, A., Costantini, A., Foresi, L.M., Lazzarotto, A., Liotta, D., Mazzanti, R. Mazzei, R., Salvatorini, G., And Sandrelli, F., 1995, Studi preliminari sul sollevamento della Toscana meridionale dopo il Pliocene medio: Studi Geologici Camerti, Special Volume 1, p. 87-91.

Bossio, A., Costantini, A., Foresi, L.M., Lazzarotto, A., Mazzanti, R., Mazzei, R., Pascucci, V., Salvatorini, G., Sandrelli, F., and Terzuoli, A., 1998, NeogeneQuaternary sedimentary evolution in the western side of the Northern Apennines (Italy): Società Geologica Italiana, Memorie, v. 52, p. 513-525.

Bossio, A., Mazzei, R., Monteforti, B., Salvatorini, G., 2000-2001, Note illustrative alla carta geologica della zona di S. Maria di Lèuca (con appendice bio-cronostratigrafica a cura di Foresi, L.M., Mazzei R., Salvatorini, G.): Società Toscana di Scienze Naturali, Atti, Memorie, Serie A, v. 106, p. 97-163.

Bossio, A., Foresi, L.M., Mazzei, R., Salvatorini, G., Sandrelli, F., Bilotti, M., Colli, A., And Rossetto, R., 2003-2004, Geology and stratigraphy of the southern sector of the Neogene Albegna River Basin (Grosseto, Tuscany, Italy): Geologica Romana, v. 37, p. $165-173$.

Brachert, T.C., Betzler, C., Braga, J.C., and Martin, J.M., 1996, Record of climatic change in neritic carbonates: turnover in biogenic associations and depositional modes (Late Miocene, southern Spain): Geologische Rundschau, v. 85, p. 327-337.

Brachert, T.C., Forst, M.H., Pais, J.J., Legoinha, P., And Reijmer, J.J.G., 2003, Lowstan carbonates, highstand sandstones?: Sedimentary Geology, v. 155, p. 1-12.

BRAGA, J.C., AND AGuirRe, J., 2001, Coralline algal assemblages in upper Neogene reef and temperate carbonates in Southern Spain: Palaeogeography, Palaeoclimatology, Palaeoecology, v. 175 , p. $27-41$

Braga, J.C., Martín, J.M., Betzler, C., and Aguirre, J., 2006, Models of temperate carbonate deposition in Neogene basins in SE Spain: a synthesis, in Pedley, H.M., and Carrannante, G., eds., Cool-Water Carbonates: Depositional Systems and Palaeoenvironmental Controls: Geological Society of London, Special Publication 255, p. 121135 .

Braga, J.C., Martín, J.M., Aguirre, J., Baird, C.D., Grunnaleite, I., Jensen, N.B., PugaBernabéu, A., Saelen, G., and Talbot, M.R., 2010, Middle Miocene (Serravallian) temperate carbonates in a seaway connecting the Atlantic Ocean and the Mediterranean Sea (North Betic Strait, S Spain): Sedimentary Geology, v. 225, p. 19-33.

Brandano, M., and Civitelli, G., 2007, Non-seagrass meadow sedimentary facies of the Pontinian Islands, Tyrrhenian Sea: a modern example of mixed carbonate-siliciclastic sedimentation: Sedimentary Geology, v. 201, p. 286-301.

Brandano, M., and Ronca, S., 2014, Depositional processes of the mixed carbonatesiliciclastic rhodolith beds of the Miocene Saint-Florent Basin, northern Corsica: Facies, v. 60 , p. $73-90$.

Brett, C.E., Mclaughlin, P.I., Histon, K., Schindler, E., and Ferretti, A., 2012, Timespecific aspects of facies: state of the art, examples, and possible causes: Palaeogeography, Palaeoclimatology, Palaeoecology, v. 367-368, p. 6-18.

Brogi, A., 2008, The structure of the Monte Amiata volcano-geothermal area (Northern Apennines, Italy): Neogene-Quaternary compression versus extension: International Journal of Earth Sciences, v. 97, p. 677-703.

Brogi, A., 2011, Bowl-shaped basin related to low-angle detachment during continental extension: the case of the controversial Neogene Siena Basin (central Italy, Northern Apennines): Tectonophysics, v. 499, p. 54-76.

Brogi, A., and Liotta, D., 2008, Highly extended terrains, lateral segmentation of the substratum, and basin development: the middle-late Miocene Radicondoli Basin (inner northern Apennines, Italy): Tectonics, v. 27, no. TC5002.

Canals, M., and Ballesteros, E., 1997, Production of carbonate particles by phytobenthic communities on the Mallorca-Menorca shelf, northwestern Mediterranean Sea: DeepSea Research Part II: Topical Studies in Oceanography, v. 44, p. 611-629.

Capezzuoli, E., Foresi, L.M., Salvatorini, G., and Sandrelli, F., 2005, New data on the Middle Pliocene sedimentation in the southern Valdelsa basin (Siena, Italy): Società Geologica Italiana, Bollettino, Special Volume 4, p. 95-103.

Capezzuoli, E., Gandin, A., And Sandrelli, F., 2006, Depositional and palaeoecological features of the Middle Pliocene (Piacenzian) marine carbonates exposed in the Valdelsa Basin (San Gimignano, Siena, Italy): GeoActa, v. 5, p. 97-112.

Capozzi, R., and Picotti, V., 2003, Pliocene sequence stratigraphy, climatic trends and sapropel formation in the Northern Apennines (Italy): Palaeogeography, Palaeoclimatology, Palaeoecology, v. 190, p. 349-371.

Carannante, G., Esteban, M., Milliman, J.D., and Simone, L., 1988, Carbonate lithofacies as paleolatitude indicators: problems and limitations: Sedimentary Geology, v. 60, p. 333-346.

Carey, J.S., Moslow, T.F., and Barrie, J.V., 1995, Origin and distribution of Holocene temperate carbonates, Hecate Strait, Western Canada continental shelf: Journal of Sedimentary Research, v. 65, p. 185-194.
Carmignani, L., Decandia, F.A., Disperati, L., Fantozzi, P.L., Kligfield, R., Lazzarotto, A., Liotta, D., And Meccheri, M., 2001, Inner Northern Apennines, in Vai, G.B., and Martini, I.P., eds., Anatomy of an Orogen: the Apennines and Adjacent Mediterranean Basins: Dordrecht, Kluwer Academic Publishers, p. 197-214.

Caron, V., Nelson, C.S., and Kamp, P.J.J., 2004, Transgressive surfaces of erosion as sequence boundary markers in cool-water shelf carbonates: Sedimentary Geology, v. 164 , p. $179-189$.

Cattaneo, A., and Steel, R.J., 2003, Transgressive deposits: a review of their variability: Earth-Science Reviews, v. 62, p. 187-228.

Catuneanu, O., 2002, Sequence stratigraphy of clastic systems: concepts, merits, and pitfalls: Journal of African Earth Sciences, v. 35, p. 1-43.

Checconi, A., Bassi, D., Passeri, L., And Rettori, R., 2007, Coralline red algal assemblage from the Middle Pliocene shallow-water temperate carbonates of the Monte Cetona (Northern Apennines, Italy): Facies, v. 53, p. 57-66.

CitA, M., 1975, Studi sul Pliocene e sugli strati di passaggio dal Miocene al Pliocene, VIII. Planktonic foraminiferal biozonation of the Mediterranean Pliocene deep sea record: a revision: Rivista Italiana di Paleontologia e Stratigrafia, v. 81, p. 527-544.

Cohen, K., Finney, S., GibBard, P., and Fan, J., 2013, The ICS International Chronostratigraphic Chart: Episodes, v. 36, p. 199-204.

Conti, M.A., PArisi, G., And Nicosia, U., 1983, Un orizzonte ad Amphistegina nel Pliocene di Orvieto e sue implicazioni tettoniche: Società Geologica Italiana, Bollettino, v. 102, p. 113-122.

Corda, L., And Brandano, M., 2003, Aphotic zone carbonate production on a Miocene ramp, Central Apennines, Italy: Sedimentary Geology, v. 161, p. 55-70.

Cornamusini, G., Lazzarotto, A., Merlini, S., and Pascucci, V., 2002, Eocene-Miocene evolution of the north Tyrrhenian Sea: Società Geologica Italiana, Bollettino, Special Volume 1, p. 769-787

Cornamusini, G., Foresi, L.M., Dall’Antonia, B., Bossio, A., Mazzei, R., and Salvatorini, G., 2014, The Miocene of the Pianosa Island: a key for the puzzle on the opening of the Northern Tyrrhenian back-arc basin (Central Mediterranean): Geological Society of London, Journal, v. 171, p. 801-819.

Costantini, A., Lazzarotto, A., Mazzanti, R., Mazzei, R., Salvatorini, G., and Sandrelli, F., 2002, Note illustrative della Carta Geologica d'Italia, foglio 285 Volterra: Roma, Servizio Geologico d'Italia, scale 1:50.000, 150 p.

Cross, N.E., And Bosence, D., 2008, Tectono-sedimentary models for rift-basin carbonate systems, in Lukasik, J., and Simo, J.A., eds., Controls on Carbonate Platform and Reef Development: SEPM, Special Publication 89, p. 83-105.

De Schepper, S., Head, M.J., and Groeneveld, J., 2009, North Atlantic Current variability through marine isotope stage M2 (circa 3.3 Ma) during the mid-Pliocene: Paleoceanography, no. PA4206, doi: 10.1029/2008PA001725.

Dini, A., Gianeldi, G., Puxeddu, M., And Ruggieri, G., 2005, Origin and evolution of Pliocene-Pleistocene granites from the Larderello geothermal field (Tuscan Magmatic Province, Italy): Lithos, v. 81, p. 1-31.

DorobeK, S.L., 2008, Tectonic and depositional controls on syn-rift carbonate platform sedimentation, in Lukasik, J., and Simo, J.A., eds., Controls on Carbonate Platform and Reef Development: SEPM, Special Publication 89, p. 57-81.

Dwyer, G.S., And Chandler, M.A., 2009, Mid-Pliocene sea level and continental ice volume based on coupled benthic $\mathrm{Mg} / \mathrm{Ca}$ palaeotemperatures and oxygen isotopes: Royal Society of London, Philosophical Transactions A, Mathematical, Physical and Engineering Sciences, v. 367 , p. $157-168$.

Esteban, M., 1996, An overview of Miocene reefs from Mediterranean areas: general trends and facies models, in Franseen, E.K., Esteban, M., Ward, W.C., and Rouchy, J. M., eds., Models for Carbonate Stratigraphy from Miocene Reef Complexes of Mediterranean Regions: SEPM, Concepts in Sedimentology and Paleontology 5, p. 354.

Fidolini, F., Ghinassi, M., Magi, M., Papini, M., And Sagri, M., 2013, The Plio-Pleistocene Upper Valdarno Basin (central Italy): stratigraphy and basin fill evolution: Italian Journal of Geosciences, v. 132, p. 13-32.

FinetTI, I.R., 2006, Basic regional crustal setting and superimposed local pluton-intrusionrelated tectonics in the Larderello-M. Amiata geothermal province, from integrated CROP seismic data: Società Geologica Italiana, Bollettino, v. 125, p. 117-146.

Fontana, D., Conti, S., Fioroni, C., And Grillenzoni, C., 2015, Factors controlling the evolution of a wedge-top temperate-type carbonate platform in the Miocene of the northern Apennines (Italy): Sedimentary Geology, v. 319, p. 13-23.

Foresi, L.M., Aldinucci, M., Sandrelli, F., and Cornamusini, G., 2008, L'Isola di Pianosa: perla neogenica dell'Arcipelago Toscano: Etrurianatura, v. 5, p. 128-151.

Fürsich, F., Werner, W., AND Schneider, S., 2009, Autochthonous to parautochthonous bivalve concentrations within transgressive marginal marine strata of the Upper Jurassic of Portugal: Palaeobiodiversity and Palaeoenvironments, v. 89, p. 161-190.

GHINASSI, M., 2005, Tectonic driven evolution of Pliocene Gilbert-type delta (Val d'Orcia Basin, southern Tuscany, Italy): GeoActa, v. 4, p. 105-122.

Gillespie, J.L., Nelson, C.S., AND Nodder, S.D., 1998, Post-glacial sea-level control and sequence stratigraphy of carbonate-terrigenous sediments, Wanganui shelf, New Zealand: Sedimentary Geology, v. 122, p. 245-266

Gläser, I., AND Betzler, C., 2002, Facies partitioning and sequence stratigraphy of coolwater, mixed carbonate-siliciclastic sediments (upper Miocene Guadalquivir Domain, southern Spain): International Journal of Earth Sciences v. 91, p. 1041-1053.

Godet, A., 2013, Drowning unconformities: palaeoenvironmental significance and involvement of global processes: Sedimentary Geology, v. 293, p. 45-66. 
Gómez-Pujol, L., Roig-Munar, F., Fornós, J., Balaguer, P., and Mateu, J., 2013 Provenance-related characteristics of beach sediments around the island of Menorca, Balearic Islands (western Mediterranean): Geo-Marine Letters, v. 33, p. 195-208.

Guillem, M.-V., Hallock, P., and Brandano, M., 2008, A depositional model and paleoecological reconstruction of the lower Tortonian distally steepened ramp of Menorca (Balearic Islands, Spain): Palaios, v. 23, p. 465-481.

Halfar, J., Godinez-Orta, L., Mutti, M., Valdez-Holguín, J.E., and Borges, J.M., 2004 Nutrient and temperature controls on modern carbonate production: an example from the Gulf of California, Mexico: Geology, v. 32, p. 213-216.

Halfar, J., Godinez-Orta, L., Mutti, M., Valdez-Holguin, J.E., and Borges, J.M., 2006, Carbonates calibrated against oceanographic parameters along a latitudinal transect in the Gulf of California, Mexico: Sedimentology, v. 53, p. 297-320.

Hallock, P., 1981, Algal symbiosis: a mathematical analysis: Marine Biology, v. 62, p. 249-255.

Hallock, P., 2000, Symbiont-bearing foraminifera: harbingers of global change? Micropaleontology, v. 46, suppl. 1, p. 95-104.

Holland, S.M., 1993, Sequence stratigraphy of a carbonate-clastic ramp: the Cincinnatian Series (Upper Ordovician) in its type area: Geological Society of America, Bulletin, v. 105 , p. 306-322.

Hollaus, S.-S., and Hottinger, L., 1997, Temperature dependence of endosymbiontic relationship? Evidence from the depth range of Mediterranean Amphistegina lessoni (Foraminiferida) truncated by the thermocline: Eclogae Geologicae Helvetiae, v. 90, p 591-597.

Hyams, O., Almogi-Labin, A., And Benjaminia, C., 2002, Larger foraminifera of the southeastern Mediterranean shallow continental shelf off Israel: Israel Journal of Earth Sciences, v. 51, p. 169-179.

Iaccarino, S., Vernia, L., Battini, P., And Gnapi, G., 1994, Osservazioni stratigrafiche sul bordo orientale del Bacino di Radicofani (Toscana meridionale): Memorie Descrittive della Carta Geologica d'Italia, v. 49, p. 151-168.

JAMES, N.P., 1997, The cool-water carbonate depositional realm, in James, N.P., and Clarke, A.D., eds., Cool-Water Carbonates: SEPM, Special Publication 56, p. 1-22.

KAMP, P.J.J., AND NAISH, T., 1998, Forward modelling of the sequence stratigraphic architecture of shelf cyclothems: application to Late Pliocene sequences, Wanganu Basin (New Zealand): Sedimentary Geology, v. 116, p. 57-80.

KLIGfield, R., 1979, The northern Apennines as a collisional orogen: American Journal of Science, v. 279, p. 676-691.

Koukousioura, O., Dimiza, M., and Triantaphyllou, M., 2010, Alien foraminifers from Greek coastal areas (Aegean Sea, eastern Mediterranean): Mediterranean Marine Science, v. 11, p. 155-172.

LANGer, M.R., AND Hottinger, L., 2000, Biogeography of selected "larger" foraminifera: Micropaleontology, v. 46, suppl. 1, p. 105-126.

Lazzarotto, A., Sandrelli, F., Foresi, L.M., Mazzei, R., Salvatorini, G., Cornamusini, G., and Pascucci, V., 2002, Note illustrative della Carta Geologica d'Italia, foglio 295 Pomarance: Roma, Servizio Geologico d'Italia, scale 1:50,000, 140 p.

LiotTA, D., 1996, Analisi del settore centro-meridionale del bacino pliocenico di Radicofani (Toscana meridionale): Società Geologica Italiana, Bollettino, v. 115, p. $115-143$.

Lisiecki, L.E., And Raymo, M.E., 2005, A Pliocene-Pleistocene stack of 57 globally distributed benthic $\delta^{18} \mathrm{O}$ records: Paleoceanography, v. 20, no. PA1003.

Lokier, S.W., Wilson, M.E.J., AND BurTon, L.M., 2009, Marine biota response to clastic sediment influx: a quantitative approach: Palaeogeography, Palaeoclimatology, Palaeoecology, v. 281, p. 25-42.

Lourens, L., Hilgen, F.J., Shackleton, N.J., Laskar, J., And Wilson, D., 2004, Appendix 2. Orbital tuning calibrations and conversions for the Neogene Period, in Gradstein, F.M. Ogg, J.G., and Smith, A.G., eds., A Geologic Time Scale 2004: Cambridge, UK, Cambridge University Press, p. 469-484.

LuKasiK, J., AND Simo, J.A., 2008, Controls on development of Phanerozoic carbonate platforms and reefs: introduction and synthesis, in Lukasik, J., and Simo, J.A., eds., Controls on Carbonate Platform and Reef Development: SEPM Special Publication 98, p. $5-12$.

Marinelli, G., Barberi, F., AND Cioni, R., 1993, Sollevamenti neogenici e intrusioni acide della Toscana e del Lazio settentrionale: Società Geologica Italiana, Memorie, v. 49, p 279-288.

Marroni, M., Moratti, G., Costantini, A., Conticelli, S., Benvenuti, M.G., Pandolfi, L., Bonini, M., Cornamusini, G., And Laurenzi, M.A., 2015, Geology of the Monte Amiata region, Southern Tuscany, Central Italy: Italian Journal of Geosciences, v. 134, p. 171199.

Martín, J.M., Braga, J.C., Betzler, C., and Brachert, T., 1996, Sedimentary model and high-frequency cyclicity in a Mediterranean, shallow-shelf, temperate-carbonate environment (uppermost Miocene, Agua Amarga Basin, Southern Spain): Sedimentology, v. 43 , p. $263-277$.

Martín, J.M., Braga, J.C., Aguirre, J., and Betzler, C., 2004, Contrasting models of temperate carbonate sedimentation in a small Mediterranean embayment: the Pliocene Carboneras Basin, SE Spain: Geological Society of London, Journal, v. 161, p. 387-399.

MARTINI, I.P., AND SAGRI, M., 1993, Tectono-sedimentary characteristics of Late MioceneQuaternary extensional basins of the Northern Apennines, Italy: Earth-Science Reviews, v. 34 , p. $197-233$

Martini, I.P., SAgri, M., And Colella, A., 2001, Neogene-Quaternary basins of the inner Apennines and Calabrian arc, in Vai, G.B., and Martini, I.P., eds., Anatomy of an
Orogen: the Apennines and Adjacent Mediterranean Basins: Dordrecht, Kluwer Academic Publishers, p. 375-400.

Martini, I., Aldinucci, M., Foresi, L.M., Mazzei, R., and Sandrelli, F., 2011, Geological map of the Pliocene succession of the Northern Siena Basin (Tuscany, Italy): Journal of Maps, v. 7, p. 193-205.

Massari, F., AND ChIOCCI, F., 2006, Biocalcarenite and mixed cool-water prograding bodies of the Mediterranean Pliocene and Pleistocene: architecture, depositional setting and forcing factors, in Pedley, H.M., and Carrannante, G., eds., Cool-Water Carbonates: Depositional Systems and Palaeoenvironmental Controls: Geological Society of London, Special Publication 255, p. 95-120.

MASSARI, F., AND D'Alessandro, A., 2012, Facies partitioning and sequence stratigraphy of a mixed siliciclastic-carbonate ramp stack in the Gelasian of Sicily (S Italy): a potential model for icehouse, distally-steepened heterozoan ramps: Rivista Italiana di Paleontologia e Stratigrafia, v. 118, p. 503-534.

McNeill, D.F., Cunningham, K.J., Guertin, L.A., and Anselmetti, F.S., 2004, Depositional themes of mixed carbonate-siliciclastics in the South Florida Neogene: application to ancient deposits, in Grammer, G.M., Harris, P.M., and Eberli, G.P., eds., Integration of Outcrop and Modern Analogs in Reservoir Modeling: American Association of Petroleum Geologists, Memoir 80, p. 23-43.

Meldahl, K.H., Yajimovich, O.G., Empedocles, C.D., Gustafson, C.S., Hidalgo, M.M., and Reardon, T.W., 1997, Holocene sediments and molluscan faunas of Bahia Conception: a modern analog to Neogene rift basins of the Gulf of California, in Johnson, M.E., and Ledesma-Vázquez, J., eds., Pliocene Carbonates and Related Facies Flanking the Gulf of California, Baja California, Mexico: Geological Society of America, Special Paper 318, p. 39-56.

Miller, K.G., Kominz, M.A., Browning, J.V., Wright, J.D., Mountain, G.S., Katz, M.E., Sugarman, P.J., Cramer, B.S., Christie-Blick, N., and Pekar, S.F., 2005, The Phanerozoic record of global sea-level change: Science, v. 310, p. 1293-1298.

Moissette, P., Cornée, J.-J., And Koskeridou, E., 2010, Pleistocene rolling stones or large bryozoan nodules in a mixed siliciclastic-carbonate environment (Rhodes, Greece): Palaios, v. 25, p. 24-39.

Monegatti, P., AND Raffi, S., 2001, Taxonomic diversity and stratigraphic distribution of Mediterranean Pliocene bivalves: Palaeogeography, Palaeoclimatology, Palaeoecology, v. 165, p. 171-193.

Mutti, M., AND Bernoulli, D., 2003, Early marine lithification and hardground development on a Miocene ramp (Maiella, Italy): key surfaces to track changes in trophic resources in nontropical carbonate settings: Journal of Sedimentary Research, v. 73, p. 296-308.

Nalin, R., And Massari, F., 2009, Facies and stratigraphic anatomy of a temperate carbonate sequence (Capo Colonna Terrace, Late Pleistocene, Southern Italy): Journal of Sedimentary Research, v. 79 , p. 210-225.

Nalin, R., Nelson, C.S., Basso, D., and Massari, F., 2008, Rhodolith-bearing limestones as transgressive marker beds: fossil and modern examples from North Island, New Zealand: Sedimentology, v. 55, p. 249-274.

Nalin, R., Ghinassi, M., AND BASso, D., 2010, Onset of temperate carbonate sedimentation during transgression in a low-energy siliciclastic embayment (Pliocene of the Val d'Orcia Basin, Tuscany, Italy): Facies, v. 56, p. 353-368.

NovaK, V., AND Renema, W., 2015, Larger foraminifera as environmental discriminators in Miocene mixed carbonate-siliciclastic systems: Palaios, v. 30, p. 40-52.

Pandeli, E., Bartolini, C., Dini, A., And Antolini, E., 2010, New data on the paleogeography of Southern Tuscany (Italy) since Late Miocene time: International Journal of Earth Sciences, v. 99, p. 1357-1381.

Pascucci, V., Merlini, S., And Martini, I.P., 1999, Seismic stratigraphy of the MiocenePleistocene sedimentary basins of the Northern Tyrrhenian Sea and western Tuscany (Italy): Basin Research, v. 11, p. 337-356.

Pascucci, V., Costantini, A., Martini, I.P., and Dringoli, R., 2006, Tectono-sedimentary analysis of a complex, extensional, Neogene basin formed on thrust-faulted, Northern Apennines hinterland: Radicofani Basin, Italy: Sedimentary Geology, v. 183, p. 71-97. Pascucci, V., Martini, I.P., SAgri, M., and Sandrelli, F., 2007, Effects of transverse structural lineaments on the Neogene-Quaternary basins of Tuscany (inner Northern Apennines, Italy), in Nichols, G., Williams, E., and Paola, C., eds., Sedimentary Processes, Environments and Basins: A Tribute to Peter Friend: International Association of Sedimentologists, Special Publication 38, p. 155-182.

Pauselli, C., Barchi, M.R., Federico, C., Magnani, M.B., and Minelli, G., 2006, The crustal structure of the northern Apennines (Central Italy): an insight by the crop03 seismic line: American Journal of Science, v. 306, p. 428-450.

Pedley, M., and Grasso, M., 2002, Lithofacies modelling and sequence stratigraphy in microtidal cool-water carbonates: a case study from the Pleistocene of Sicily, Italy: Sedimentology, v. 49, p. 533-553.

Peña, V., And BÁrbara, I., 2008, Maërl community in the north-western Iberian Peninsula: a review of floristic studies and long-term changes: Aquatic Conservation: Marine and Freshwater Ecosystems, v. 18, p. 339-366.

Pomar, L., 2001, Types of carbonate platforms: a genetic approach: Basin Research, v. 13, p. 313-334.

Pomar, L., and Tropeano, M., 2001, The Calcarenite di Gravina Formation in Matera (Southern Italy): new insights for coarse-grained, large-scale, cross-bedded bodies encased in offshore deposits: American Association of Petroleum Geologists, Bulletin, v. 85 , p. $661-689$. 
Pomar, L., Brandano, M., and Westrhal, H., 2004, Environmental factors influencing skeletal grain sediment associations: a critical review of Miocene examples from the western Mediterranean: Sedimentology, v. 51, p. 627-651.

Pomar, L., AND Kendall, C.G. St.C., 2008, Architecture of carbonate platforms: a response to hydrodynamics and evolving ecology, in Lukasik, J., and Simo, J.A., eds., Controls on Carbonate Platform and Reef Development: SEPM, Special Publication 89, p. 187-216.

Puga-Bernabéu, Á., Martín, J.M., Braga, J.C., And Sánchez-Almazo, I.M., 2010 Downslope-migrating sandwaves and platform-margin clinoforms in a currentdominated, distally steepened temperate-carbonate ramp (Guadix Basin, Southern Spain): Sedimentology, v. 57, p. 293-311.

Quiquerez, A., AND Dromart, G., 2006, Environmental control on granular clinoforms of ancient carbonate shelves: Geological Magazine, v. 143, p. 343-365.

Rankey, E.C., Bachtel, S.L., AND Kaufman, J., 1999, Controls on stratigraphic architecture of icehouse mixed carbonate-siliciclastic systems: a case study from the Holder Formation (Pennsylvanian, Virgilian), Sacramento Mountains, New Mexico, in Harris, P.M., Saller, A.H., and Simo, J.A., eds., Advances in Carbonate Sequence Stratigraphy: Application to Reservoirs, Outcrops and Models: SEPM, Special Publication 63, p. 127 150 .

Reuter, M., Brachert, T.C., And Kroeger, K.F., 2006, Shallow-marine carbonates of the tropical-temperature transition zone: effects of hinterland climate and basin physiography (late Miocene, Crete, Greece), in Pedley, H.M., and Carrannante, G., eds., CoolWater Carbonates: Depositional Systems and Palaeoenvironmental Controls: Geological Society of London, Special Publication 255, p. 157-178.

Riforgiato, F., Foresi, L., Mazzei, R., Salvatorini, G., and Sandrelli, F., 2005 , Chronostratigraphic revision of some Pliocene basins in Tuscany at the Zanclean Piacenzian boundary: Società Geologica Italiana, Bollettino, Special Volume 3, p. 7-13

Rio, D., RafFi, I., and Villa, G., 1990, Pliocene-Pleistocene calcareous nannofossil distribution patterns in the Western Mediterranean, in Kastens, K.A., and Mascle, J. eds., Proceedings of the Ocean Drilling Program, Scientific Results, v. 107: College Station, Texas, p. 513-533.

Ryan, D.A., Brooke, B.P., Collins, L.B., Spooner, M.I., and Siwabessy, P.J.W., 2008 , Formation, morphology and preservation of high-energy carbonate lithofacies: Evolution of the cool-water Recherche Archipelago inner shelf, south-western Australia: Sedimentary Geology, v. 207, p. 41-55.

Saura, E., Embry, J.-C., Vergés, J., Hunt, D.W., Casciello, E., and Homke, S., 2013 Growth fold controls on carbonate distribution in mixed foreland basins: insights from the Amiran foreland basin (NW Zagros, Iran) and stratigraphic numerical modelling: Basin Research, v. 25, p. 149-171.

SChlager, W., 1991, Depositional bias and environmental change: important factors in sequence stratigraphy: Sedimentary Geology, v. 70, p. 109-130.

Schlager, W., 2003, Benthic carbonate factories of the Phanerozoic: International Journal of Earth Sciences, v. 92, p. 445-464.
Sciberras, M., Rizzo, M., Mifsud, J.R., Camilleri, K., Borg, J.A., Lanfranco, E., and SCHEMBRI, P.J., 2009, Habitat structure and biological characteristics of a maerl bed off the northeastern coast of the Maltese Islands (central Mediterranean): Marine Biodiversity, v. 39, p. 251-264.

Shackleton, N.J., 1995, Pliocene stable isotope stratigraphy of Site 846, in Pisias, N.G., Mayer, L.A., Janecek, T.R., Palmer-Julson, A., and van Andel, T.H., eds., Proceedings of the Ocean Drilling Program, Scientific Results, v. 138: College Station, Texas, p. 337 355

SPROVIERI, R., 1992, Mediterranean Pliocene biochronology: a high resolution record based on quantitative planktonic foraminifera distribution: Rivista Italiana di Paleontologia e Stratigrafia, v. 98, p. 61-100.

Triantaphyllou, M., Koukousioura, O., and Dimiza, M., 2009, The presence of the IndoPacific symbiont-bearing foraminifer Amphistegina lobifera in Greek coastal ecosystems (Aegean Sea, Eastern Mediterranean): Mediterranean Marine Science, v. 10, p. 73-86.

VecseI, A., AND SANDERs, D.G.K., 1999, Facies analysis and sequence stratigraphy of a Miocene warm-temperate carbonate ramp, Montagna della Maiella, Italy: Sedimentary Geology, v. 123, p. 103-127.

Vigorito, M., Murru, M., And Simone, L., 2010, Carbonate production in rift basins: models for platform inception, growth and dismantling, and for shelf to basin sediment transport, Miocene Sardinia Rift Basin, Italy, in Mutti, M., Piller, W., and Betzler, C., eds., Carbonate Systems during the Oligocene-Miocene Climatic Transition, International Association of Sedimentologists, Special Publication 42, p. 257-282.

Westphal, H., Halfar, J., and Freiwald, A., 2010, Heterozoan carbonates in subtropical to tropical settings in the present and past: International Journal of Earth Sciences, v. 99, p. 153-169.

WiLson, M.E.J., AND VecseI, A., 2005, The apparent paradox of abundant foramol facies in low latitudes: their environmental significance and effect on platform development: Earth-Science Reviews, v. 69, p. 133-168.

Wilson, S., Blake, C., Berges, J.A., and Maggs, C.A., 2004, Environmental tolerances of free-living coralline algae (maerl): implications for European marine conservation: Biological Conservation, v. 120, p. 279-289.

Yokes, M.B., Meric, E., And Avsar, N., 2007, On the presence of alien foraminifera Amphistegina lobifera Larsen on the coasts of the Maltese Islands: Aquatic Invasions, v. 2, p. $439-441$.

Zeller, M., Verwer, K., Eberli, G.P., Massaferro, J.L., Schwarz, E., and Spalletti, L., 2015, Depositional controls on mixed carbonate-siliciclastic cycles and sequences on gently inclined shelf profiles: Sedimentology, v. 62, p. 2009-2037.

Received 5 December 2014; accepted 4 November 2015 